Cochrane Database of Systematic Reviews

\title{
Nutrient-enriched formula versus standard formula for preterm infants following hospital discharge (Review)
}

Young L, Embleton ND, McGuire W

Young L, Embleton ND, McGuire W.

Nutrient-enriched formula versus standard formula for preterm infants following hospital discharge.

Cochrane Database of Systematic Reviews 2016, Issue 12. Art. No.: CD004696.

DOI: 10.1002/14651858.CD004696.pub5.

www.cochranelibrary.com 
TABLE OF CONTENTS

HEADER 1

ABSTRACT

PLAIN LANGUAGE SUMMARY

SUMMARY OF FINDINGS

BACKGROUND

OBJECTIVES

METHODS

RESULTS

Figure 1.

Figure 2.

Figure 3.

Figure 4.

Figure 5.

Figure 6.

Figure 7.

Figure 8.

DISCUSSION

AUTHORS' CONCLUSIONS

ACKNOWLEDGEMENTS

REFERENCES

CHARACTERISTICS OF STUDIES

DATA AND ANALYSES

Analysis 1.1. Comparison 1 Postdischarge formula versus standard term formula, Outcome 1 Growth rates during trial period.

Analysis 1.2. Comparison 1 Postdischarge formula versus standard term formula, Outcome 2 Weight (grams).

Analysis 1.3. Comparison 1 Postdischarge formula versus standard term formula, Outcome 3 Crown-heel length (mm).

Analysis 1.4. Comparison 1 Postdischarge formula versus standard term formula, Outcome 4 Head circumference $(\mathrm{mm})$.

Analysis 1.5. Comparison 1 Postdischarge formula versus standard term formula, Outcome 5 Development.

Analysis 1.6. Comparison 1 Postdischarge formula versus standard term formula, Outcome 6 Bone mineralisation.

Analysis 2.1. Comparison 2 Preterm formula versus standard term formula, Outcome 1 Growth rates during trial period.

Analysis 2.2. Comparison 2 Preterm formula versus standard term formula, Outcome 2 Weight (grams).

Analysis 2.3. Comparison 2 Preterm formula versus standard term formula, Outcome 3 Crown-heel length (mm).

Analysis 2.4. Comparison 2 Preterm formula versus standard term formula, Outcome 4 Head circumference (mm).

Analysis 2.5. Comparison 2 Preterm formula versus standard term formula, Outcome 5 Development.

WHAT'S NEW

HISTORY

CONTRIBUTIONS OF AUTHORS

DECLARATIONS OF INTEREST

SOURCES OF SUPPORT

DIFFERENCES BETWEEN PROTOCOL AND REVIEW

INDEX TERMS 
[Intervention Review]

\section{Nutrient-enriched formula versus standard formula for preterm infants following hospital discharge}

Lauren Young1, Nicholas D Embleton², William McGuire3

1Paediatric Intensive Care Unit, Birmingham Children's Hospital, Birmingham, UK. 2 Newcastle Neonatal Service, Newcastle Hospitals NHS Foundation Trust and University of Newcastle, Newcastle upon Tyne, UK. ${ }^{3}$ Centre for Reviews and Dissemination, York, UK

Contact address: William McGuire, Centre for Reviews and Dissemination, The University of York, York, Y010 5DD, UK.

William.McGuire@hyms.ac.uk.

Editorial group: Cochrane Neonatal Group.

Publication status and date: New search for studies and content updated (no change to conclusions), published in Issue 12, 2016.

Citation: Young L, Embleton ND, McGuire W. Nutrient-enriched formula versus standard formula for preterm infants following hospital discharge. Cochrane Database of Systematic Reviews 2016, Issue 12. Art. No.: CD004696. DOI: 10.1002/14651858.CD004696.pub5.

Copyright @ 2016 The Cochrane Collaboration. Published by John Wiley \& Sons, Ltd.

\section{A B S T R A C T}

\section{Background}

Preterm infants are often growth-restricted at hospital discharge. Feeding nutrient-enriched formula rather than standard formula to infants after hospital discharge might facilitate 'catch-up' growth and might improve development.

\section{Objectives}

To compare the effects of nutrient-enriched formula versus standard formula on growth and development of preterm infants after hospital discharge.

\section{Search methods}

We used the standard search strategy of the Cochrane Neonatal Review Group. This included searches of the Cochrane Central Register of Controlled Trials (2016, Issue 8) in the Cochrane Library, MEDLINE, Embase and the Cumulative Index to Nursing and Allied Health Literature (CINAHL; to 8 September 2016), as well as conference proceedings and previous reviews.

\section{Selection criteria}

Randomised and quasi-randomised controlled trials that compared the effects of feeding nutrient-enriched formula (postdischarge formula or preterm formula) versus standard term formula to preterm infants after hospital discharge .

\section{Data collection and analysis}

Two review authors assessed trial eligibility and risk of bias and extracted data independently. We analysed treatment effects as described in the individual trials and reported risk ratios and risk differences for dichotomous data, and mean differences (MDs) for continuous data, with respective $95 \%$ confidence intervals (Cls). We used a fixed-effect model in meta-analyses and explored potential causes of heterogeneity by performing sensitivity analyses. We assessed quality of evidence at the outcome level using the Grading of Recommendations Assessment, Development and Evaluation (GRADE) approach.

\section{Main results}

We included 16 eligible trials with a total of 1251 infant participants. Trials were of variable methodological quality, with lack of allocation concealment and incomplete follow-up identified as major potential sources of bias. Trials $(\mathrm{N}=11)$ that compared feeding infants with 'postdischarge formula' (energy density about $74 \mathrm{kcal} / 100 \mathrm{~mL}$ ) versus standard term formula (about $67 \mathrm{kcal} / 100 \mathrm{~mL}$ ) did not find consistent evidence of effects on growth parameters up to 12 to 18 months post term. GRADE assessments indicated that evidence was of moderate quality, and that inconsistency within pooled estimates was the main quality issue. 
Trials $(\mathrm{N}=5$ ) that compared feeding with 'preterm formula' (about $80 \mathrm{kcal} / 100 \mathrm{~mL}$ ) versus term formula found evidence of higher rates of growth throughout infancy (weighted mean differences at 12 to 18 months post term: about $500 \mathrm{~g}$ in weight, 5 to $10 \mathrm{~mm}$ in length, 5 $\mathrm{mm}$ in head circumference). GRADE assessments indicated that evidence was of moderate quality, and that imprecision of estimates was the main quality issue.

Few trials assessed neurodevelopmental outcomes, and these trials did not detect differences in developmental indices at 18 months post term. Data on growth or development through later childhood have not been provided.

\section{Authors' conclusions}

Recommendations to prescribe 'postdischarge formula' for preterm infants after hospital discharge are not supported by available evidence. Limited evidence suggests that feeding 'preterm formula' (which is generally available only for in-hospital use) to preterm infants after hospital discharge may increase growth rates up to 18 months post term.

\section{PLAIN LANGUAGE SUMMARY}

\section{Nutrient-enriched formula versus standard term formula for preterm infants following hospital discharge}

Review question: Does feeding preterm infants formula enriched with extra nutrients versus standard formula (designed for term infants) after hospital discharge increase growth rate and improve development?

Background: By the time preterm infants are ready to go home from the hospital after receiving care since birth, many are smaller and weigh less than they would have had they stayed in the womb instead of being born early. It may be that feeding preterm infants a formula enriched with extra nutrients (rather than standard formula used to feed term infants) helps them grow more quickly (and catch up with infants born at term) while improving their development.

Study characteristics: We identified 16 eligible trials enrolling a total of 1251 infants through searches updated to 8 September 2016.

Key findings: These trials provide moderate-quality evidence that unrestricted feeding with nutrient-enriched (vs standard) formula does not have important effects on growth and development up to about 18 months of age. Long-term growth and development have not yet been assessed.

Conclusions: Current recommendations to prescribe nutrient-enriched formula for preterm infants after hospital discharge are not supported by available evidence. 


\section{SUMMARY OF FINDINGS}

Summary of findings for the main comparison. Postdischarge formula compared with standard term formula for preterm infants after hospital discharge

\section{Postdischarge formula compared with standard term formula for preterm infants after hospital discharge}

Patient or population: preterm infants after hospital discharge

Setting: community

Intervention: postdischarge formula

Comparison: standard term formula

\begin{tabular}{|c|c|c|c|c|}
\hline \multirow[t]{2}{*}{ Outcomes } & $\begin{array}{l}\text { Anticipated absolute effects* } \\
(95 \% \mathrm{Cl})\end{array}$ & \multirow[t]{2}{*}{$\begin{array}{l}\text { Number of par- } \\
\text { ticipants } \\
\text { (studies) }\end{array}$} & \multirow[t]{2}{*}{$\begin{array}{l}\text { Quality of the } \\
\text { evidence } \\
\text { (GRADE) }\end{array}$} & \multirow[t]{2}{*}{ Comments } \\
\hline & $\begin{array}{l}\text { Postdischarge formula vs stan- } \\
\text { dard term formula }\end{array}$ & & & \\
\hline $\begin{array}{l}\text { Weight (grams) } 3-4 \\
\text { months post term }\end{array}$ & $\begin{array}{l}\text { MD } 7.45 \text { g lower } \\
\text { (141.84 lower to } 126.93 \text { higher) }\end{array}$ & $\begin{array}{l}523 \\
\text { (6 RCTs) }\end{array}$ & $\begin{array}{l}\oplus \oplus \oplus \odot \\
\text { Moderate }\end{array}$ & $\begin{array}{l}\text { Downgraded for moder- } \\
\text { ate inconsistency }\left(1^{2}=\right. \\
62 \%)\end{array}$ \\
\hline $\begin{array}{l}\text { Weight (grams) } 6 \text { months } \\
\text { post term }\end{array}$ & $\begin{array}{l}\text { MD } 35.54 \mathrm{~g} \text { higher } \\
\text { (113.71 lower to } 184.78 \text { higher) }\end{array}$ & $\begin{array}{l}576 \\
\text { ( } 7 \text { studies) }\end{array}$ & $\begin{array}{l}\oplus \oplus \oplus \odot \\
\text { Moderate }\end{array}$ & $\begin{array}{l}\text { Downgraded for incon- } \\
\text { sistency moderate }\left(I^{2}=\right. \\
64 \%) .\end{array}$ \\
\hline $\begin{array}{l}\text { Crown-heel length }(\mathrm{mm}) \\
\text { 3-4 months post term }\end{array}$ & $\begin{array}{l}\text { MD } 2.45 \mathrm{~mm} \text { higher } \\
\text { (2.01 lower to } 6.9 \text { higher) }\end{array}$ & $\begin{array}{l}523 \\
\text { (6 RCTs) }\end{array}$ & $\begin{array}{l}\oplus \oplus \oplus \odot \\
\text { Moderate }\end{array}$ & $\begin{array}{l}\text { Downgraded for high } \\
\text { inconsistency }\left(I^{2}=81 \%\right)\end{array}$ \\
\hline $\begin{array}{l}\text { Crown-heel length }(\mathrm{mm}) 6 \\
\text { months post term }\end{array}$ & $\begin{array}{l}\text { MD } 2.12 \mathrm{~mm} \text { higher } \\
\text { (2.16 lower to } 6.41 \text { higher) }\end{array}$ & $\begin{array}{l}576 \\
\text { ( } 7 \text { studies) }\end{array}$ & $\begin{array}{l}\oplus \oplus \oplus \odot \\
\text { Moderate }\end{array}$ & $\begin{array}{l}\text { Downgraded for moder- } \\
\text { ate inconsistency }\left(1^{2}=\right. \\
75 \%)\end{array}$ \\
\hline $\begin{array}{l}\text { Head circumference }(\mathrm{mm}) \\
\text { 3-4 months post term }\end{array}$ & $\begin{array}{l}\text { MD } 0.3 \mathrm{~mm} \text { lower } \\
\text { ( } 2.86 \text { lower to } 2.26 \text { higher) }\end{array}$ & $\begin{array}{l}523 \\
\text { (6 studies) }\end{array}$ & $\begin{array}{l}\oplus \oplus \oplus \odot \\
\text { Moderate }\end{array}$ & $\begin{array}{l}\text { Downgraded for moder- } \\
\text { ate inconsistency }\left(1^{2}=\right. \\
71 \%)\end{array}$ \\
\hline $\begin{array}{l}\text { Head circumference }(\mathrm{mm}) \\
6 \text { months post term }\end{array}$ & $\begin{array}{l}\text { MD } 2.28 \mathrm{~mm} \text { higher } \\
\text { ( } 0.28 \text { lower to } 4.83 \text { higher) }\end{array}$ & $\begin{array}{l}576 \\
\text { ( } 7 \text { studies) }\end{array}$ & $\begin{array}{l}\oplus \oplus \oplus \odot \\
\text { Moderate }\end{array}$ & $\begin{array}{l}\text { Downgraded for moder- } \\
\text { ate inconsistency }\left(1^{2}=\right. \\
69 \%)\end{array}$ \\
\hline $\begin{array}{l}\text { Development - Bayley } \\
\text { Scales of Infant Develop- } \\
\text { ment II: Mental Develop- } \\
\text { ment Index }\end{array}$ & $\begin{array}{l}\text { MD } 0.9 \text { higher } \\
\text { (3.24 lower to } 5.04 \text { higher) }\end{array}$ & $\begin{array}{l}184 \\
(1 \mathrm{RCT})\end{array}$ & $\begin{array}{l}\oplus \oplus \oplus \oplus \\
\text { High }\end{array}$ & \\
\hline
\end{tabular}

\section{Summary of findings 2. Preterm formula compared with standard term formula for preterm infants after hospital discharge}

\section{Preterm formula compared with standard term formula for preterm infants after hospital discharge}

Patient or population: preterm infants after hospital discharge

Setting: community

Intervention: preterm formula 
Comparison: standard term formula

\begin{tabular}{|c|c|c|c|c|}
\hline \multirow[t]{2}{*}{ Outcomes } & $\begin{array}{l}\text { Anticipated absolute effects* }(95 \% \\
\mathrm{CI})\end{array}$ & \multirow[t]{2}{*}{$\begin{array}{l}\text { Number of par- } \\
\text { ticipants } \\
\text { (studies) }\end{array}$} & \multirow[t]{2}{*}{$\begin{array}{l}\text { Quality of the } \\
\text { evidence } \\
\text { (GRADE) }\end{array}$} & \multirow[t]{2}{*}{ Comments } \\
\hline & $\begin{array}{l}\text { Preterm formula vs standard term } \\
\text { formula }\end{array}$ & & & \\
\hline $\begin{array}{l}\text { Weight (grams) 3-4 months } \\
\text { post term }\end{array}$ & $\begin{array}{l}\text { MD } 74.41 \mathrm{~g} \text { higher } \\
\text { (267.1 lower to } 415.93 \text { higher) }\end{array}$ & $\begin{array}{l}130 \\
(3 \mathrm{RCTS})\end{array}$ & $\begin{array}{l}\oplus \oplus \oplus \ominus \\
\text { Moderate }\end{array}$ & $\begin{array}{l}\text { Downgraded for } \\
\text { imprecision }\end{array}$ \\
\hline $\begin{array}{l}\text { Weight (grams) } 6 \text { months } \\
\text { post term }\end{array}$ & $\begin{array}{l}\text { MD } 74.6 \mathrm{~g} \text { higher } \\
\text { (164.73 lower to } 313.92 \text { higher) }\end{array}$ & $\begin{array}{l}273 \\
(4 \mathrm{RCTs})\end{array}$ & $\begin{array}{l}\oplus \oplus \oplus \ominus \\
\text { Moderate }\end{array}$ & $\begin{array}{l}\text { Downgraded for } \\
\text { imprecision }\end{array}$ \\
\hline $\begin{array}{l}\text { Crown-heel length }(\mathrm{mm}) 3-4 \\
\text { months post term }\end{array}$ & $\begin{array}{l}\text { MD } 2.27 \text { mm lower } \\
\text { (13.09 lower to } 8.56 \text { higher) }\end{array}$ & $\begin{array}{l}130 \\
(3 \mathrm{RCTs})\end{array}$ & $\begin{array}{l}\oplus \oplus \oplus \ominus \\
\text { Moderate }\end{array}$ & $\begin{array}{l}\text { Downgraded for } \\
\text { imprecision }\end{array}$ \\
\hline $\begin{array}{l}\text { Crown-heel length }(\mathrm{mm}) 6 \\
\text { months post term }\end{array}$ & $\begin{array}{l}\text { MD } 1.83 \mathrm{~mm} \text { higher } \\
\text { (6.25 lower to } 9.92 \text { higher) }\end{array}$ & $\begin{array}{l}160 \\
(3 \mathrm{RCTS})\end{array}$ & $\begin{array}{l}\oplus \oplus \oplus \ominus \\
\text { Moderate }\end{array}$ & $\begin{array}{l}\text { Downgraded for } \\
\text { imprecision }\end{array}$ \\
\hline $\begin{array}{l}\text { Head circumference }(\mathrm{mm}) \\
\text { 3-4 months post term }\end{array}$ & $\begin{array}{l}\text { MD } 3.61 \mathrm{~mm} \text { higher } \\
\text { ( } 2.09 \text { lower to } 9.31 \text { higher) }\end{array}$ & $\begin{array}{l}130 \\
\text { (3 RCTs) }\end{array}$ & $\begin{array}{l}\oplus \oplus \oplus \odot \\
\text { Moderate }\end{array}$ & $\begin{array}{l}\text { Downgraded for } \\
\text { imprecision }\end{array}$ \\
\hline $\begin{array}{l}\text { Head circumference }(\mathrm{mm}) 6 \\
\text { months post term }\end{array}$ & $\begin{array}{l}\text { MD } 5.82 \mathrm{~mm} \text { higher } \\
\text { (1.32 higher to } 10.32 \text { higher) }\end{array}$ & $\begin{array}{l}160 \\
\text { (3 RCTs) }\end{array}$ & $\begin{array}{l}\oplus \oplus \oplus \ominus \\
\text { Moderate }\end{array}$ & $\begin{array}{l}\text { Downgraded for } \\
\text { imprecision }\end{array}$ \\
\hline $\begin{array}{l}\text { Development - Bayley Scales } \\
\text { of Infant Development II: } \\
\text { Mental Development Index }\end{array}$ & $\begin{array}{l}\text { MD } 1.44 \text { lower } \\
\text { (6.22 lower to } 3.35 \text { higher) }\end{array}$ & $\begin{array}{l}143 \\
(2 \mathrm{RCTs})\end{array}$ & $\begin{array}{l}\oplus \oplus \oplus \oplus \\
\text { High }\end{array}$ & \\
\hline
\end{tabular}




\section{B A C K G R O U N D}

Compared with term infants, preterm infants have limited nutrient reserves at birth. Also, preterm infants, especially very preterm and very low birth weight (VLBW) infants, are subject to a variety of physiological and metabolic stresses that increase their nutrient needs. Recommended nutrient requirements for preterm infants are based on intrauterine growth studies and assume that the optimal rate of postnatal growth should be about the same as that of uncompromised fetuses of an equivalent postmenstrual age. Evidence indicates, however, that recommended target levels of nutrient input are rarely achieved in practice, and that most very preterm or VLBW infants accumulate significant energy, protein, mineral and other nutrient deficits during their initial hospital stay (Embleton 2001). By the time they are ready to go home, typically at around 36 to 40 weeks' postmenstrual age, many infants are substantially growth-restricted relative to their term-born peers (Clark 2003; Dusick 2003; Lucas 1984).

\section{Description of the condition}

After hospital discharge, responsively (demand) fed preterm infants often consume relatively more milk than term infants to attain 'catch-up' growth (Lucas 1992a). Despite this, growth deficits can persist through childhood and adolescence (Bracewell 2008; Farooqi 2006; Ford 2000; Trebar 2007). Slow or incomplete catchup growth is associated with higher risk of neurodevelopmental impairment in later childhood, and with poorer cognitive and educational outcomes (Cooke 2003; Hack 1991; Leppanen 2014). Preterm infants who have accumulated mineral deficits have higher risks of metabolic bone disease and slower skeletal growth compared with infants born at term, although uncertainty remains about long-term effects of such deficits on bone mass and health (Fewtrell 2011). Furthermore, nutritional deficiency and growth restriction in utero and during early infancy may have consequences for long-term metabolic and cardiovascular health (Embleton 2013; Lapillonne 2013).

\section{Description of the intervention}

Because slow or incomplete catch-up growth is associated with prolonged growth restriction and slower neurodevelopmental progression, attention has focused on nutritional interventions that might promote growth during the putative 'critical window' of early infancy in the post-hospital discharge period. Two broad strategies for nutritional interventions are known (Dusick 2003; Fewtrell 2003; Klingenberg 2011).

- Multi-nutrient fortification of expressed milk for infants fed with human breast milk.

- Nutrient-enriched formula for formula-fed infants.

Another Cochrane review addresses the question of whether multi-nutrient fortification of human breast milk affects growth and development in preterm infants after hospital discharge (McCormick 2013). This review focuses on the comparison of nutrient-enriched formula versus standard formula for formula-fed preterm infants after hospital discharge.

A variety of standard and nutrient-enriched formula preparations are available (Aggett 2006; Griffin 2007). These can be categorised broadly as:
- standard term formula: designed for term infants, based on the composition of mature human breast milk. The typical energy content is 66 to $68 \mathrm{kcal} / 100 \mathrm{~mL}$. The concentration of protein approximately 1.4 to $1.7 \mathrm{~g} / 100 \mathrm{~mL}$ - and calcium and phosphate content (about $50 \mathrm{mg} / 100 \mathrm{~mL}$ and $30 \mathrm{mg} / 100 \mathrm{~mL}$, respectively) are not sufficient to satisfy recommended nutrient needs for stable and growing preterm infants;

- postdischarge formula: specifically designed for preterm infants post discharge from the hospital. These are energy (about 72 to $74 \mathrm{kcal} / 100 \mathrm{~mL}$ ) and protein (about 1.8 to $1.9 \mathrm{~g} / 100 \mathrm{~mL}$ ) enriched and are variably enriched with minerals, vitamins and trace elements compared with standard term formula. Expert bodies and authorities recommend these formulas for preterm infants for three to 12 months post discharge (Aggett 2006); and

- preterm formula: energy-enriched (about $80 \mathrm{kcal} / 100 \mathrm{~mL}$ ), protein-enriched (2.0 to $2.4 \mathrm{~g} / 100 \mathrm{~mL}$ ) and variably enriched with minerals, vitamins and trace elements to support intrauterine nutrient accretion rates. These formulas are commonly used for nutrition of preterm infants before hospital discharge and generally are not recommended for postdischarge feeding.

\section{How the intervention might work}

Feeding preterm infants after hospital discharge formula enriched with extra energy, protein, minerals and vitamins may be expected to promote rapid catch-up growth. However, because preterm infants fed in response to hunger and satiation cues (demand or responsive feeding) adjust their volume of intake according to the energy density of formula, infants may consume less nutrientenriched milk than standard formula (Lucas 1992a). Consequently, infants fed responsively with preterm or postdischarge formula may not receive any more energy (or other nutrients, depending on the nutrient:energy ratio) than infants fed standard term formula.

Feeding of nutrient-enriched formula may be associated with disordered gastric motility and emptying (Hancock 1984; Siegel 1984). Nutrient-enriched formula may therefore be poorly tolerated, thereby reducing nutrient delivery and potentially removing any benefit for growth and development. Furthermore, catch-up growth with accelerated weight gain and crossing of body mass index (BMI) percentiles might be associated with altered fat distribution and related 'programmed' metabolic consequences that may increase the risk of insulin resistance and cardiovascular disease (Doyle 2004; Euser 2005; Euser 2008; Hack 2003; Saigal 2006).

\section{Why it is important to do this review}

Given the potential for postdischarge nutrition strategies to affect growth and development in preterm infants, and the fact that uncertainty surrounds the balance between putative benefits and harms, this review was undertaken to detect, appraise and synthesise available evidence from randomised controlled trials to inform practice and research.

\section{O B JECTIVES}

To compare the effects of nutrient-enriched formula versus standard formula on growth and development of preterm infants after hospital discharge. 


\section{METHODS}

\section{Criteria for considering studies for this review}

\section{Types of studies}

We included controlled trials using random or quasi-random patient allocation, including cluster-randomised controlled trials. We did not include cross-over trials. Studies published as abstracts were eligible for inclusion only if assessment of study quality was possible, and if other criteria for inclusion were fulfilled.

\section{Types of participants}

We included preterm infants fed formula (exclusively or as a supplement to human breast milk) after discharge from hospital. The intervention may have commenced up to one week before planned discharge from hospital. We did not include in this review trials that randomly assigned infants to nutrient-enriched formula versus standard term formula more than one week before hospital discharge (and then continued the intervention after hospital discharge).

\section{Types of interventions}

- Standard term formula: energy content $\leq 72 \mathrm{kcal} / 100 \mathrm{~mL}$ and protein content $\leq 1.7 \mathrm{~g} / 100 \mathrm{~mL}$

versus

- Postdischarge formula: energy content $>72 \mathrm{kcal} / 100 \mathrm{~mL}$ (but $\leq$ $75 \mathrm{kcal} / 100 \mathrm{~mL}$ ) and protein content $>1.7 \mathrm{~g} / 100 \mathrm{~mL}$; or

- Preterm formula: energy content $>75 \mathrm{kcal} / 100 \mathrm{~mL}$ and protein content $>2.0 \mathrm{~g} / 100 \mathrm{~mL}$.

The formula could be fed as the sole diet or as a supplement to human breast milk. Infants in trial groups should have received similar care other than the type of formula. Target levels prescribed for volume of intake and advice or support for demand feeding should have been no different among groups.

\section{Types of outcome measures}

\section{Primary outcomes}

- Growth: weight, length, head growth, skinfold thickness, BMI and measures of body composition (lean/fat mass) and growth restriction (proportion of infants who remain $<10$ th percentile for distribution of weight, length or head circumference in the index population). Long-term growth and growth restriction (proportion of infants who remain below the 10th percentile for distribution of weight, height or head circumference in the index population)

- Development

* Neurodevelopmental outcomes assessed by validated tools at $\geq 12$ months' corrected age; classifications of disability, including non-ambulant cerebral palsy, developmental delay and auditory and visual impairment

* Cognitive and educational outcomes at $\geq 5$ years: intelligence quotient and/or indices of educational achievement measured by a validated tool (including school examination results)

\section{Secondary outcomes}

- Feed intolerance such as vomiting or diarrhoea that necessitates ceasing the study formula

- Measures of bone mineralisation such as serum alkaline phosphatase level, or assessment of bone mineral content by dual-energy $\mathrm{X}$-ray absorptiometry and clinical or radiological evidence of rickets on long-term follow-up

- Blood pressure on long-term follow-up

- Body mass index or other measures of overweight or obesity on long-term follow-up

\section{Search methods for identification of studies}

We used the standard search strategy of the Cochrane Neonatal Review Group.

\section{Electronic searches}

We updated the search on 8 September 2016 using a combination of the following terms: (infant nutrition OR infant formula OR milk OR formula OR nutrient OR fortif* OR supplemt ${ }^{\star}$ ) AND (postdischarge OR post-discharge OR discharge) plus the following databasespecific terms limited by relevant search filters for clinical trials, as recommended in the Cochrane Handbook for Systematic Reviews of Interventions.

- PubMed: ((infant, newborn[MeSH] OR newborn OR neonate OR neonatal OR premature OR low birth weight OR VLBW OR LBW or infan* or neonat*) AND (randomized controlled trial [pt] OR controlled clinical trial [pt] OR randomized [tiab] OR placebo [tiab] OR drug therapy [sh] OR randomly [tiab] OR trial [tiab] OR groups [tiab]) NOT (animals [mh] NOT humans [mh]))

- Embase: (infant, newborn or newborn or neonate or neonatal or premature or very low birth weight or low birth weight or VLBW or LBW or Newborn or infan* or neonat*) AND (human not animal) AND (randomized controlled trial or controlled clinical trial or randomized or placebo or clinical trials as topic or randomly or trial or clinical trial)

- Cumulative Index to Nursing and Allied Health Literature (CINAHL): (infant, newborn OR newborn OR neonate OR neonatal OR premature OR low birth weight OR VLBW OR LBW or Newborn or infan* or neonat*) AND (randomized controlled trial OR controlled clinical trial OR randomized OR placebo OR clinical trials as topic OR randomly OR trial OR PT clinical trial)

- Cochrane Library: (infant or newborn or neonate or neonatal or premature or very low birth weight or low birth weight or VLBW or LBW)

We applied no language restrictions.

We searched ClinicalTrials.gov and Current Controlled Trials for completed and ongoing trials.

\section{Searching other resources}

We examined the references provided in studies identified as potentially relevant. We searched abstracts from annual meetings of the Pediatric Academic Societies (1993 to 2016), the European Society for Pediatric Research (1995 to 2016), the UK Royal College of Paediatrics and Child Health (2000 to 2016) and the Perinatal Society of Australia and New Zealand (2000 to 2016). We considered trials reported only as abstracts to be eligible 
if sufficient information was available from the report, or from contact with study authors, to fulfil the inclusion criteria.

\section{Data collection and analysis}

We used the standard methods of the Cochrane Neonatal Review Group.

\section{Selection of studies}

Two review authors screened the titles and abstracts of all studies identified by the above search strategy. We reassessed the full texts of potentially eligible reports and excluded studies that did not meet all of the inclusion criteria. We discussed disagreements until consensus was achieved.

\section{Data extraction and management}

We used a data collection form to aid extraction of relevant information from each included study. Two review authors extracted study data separately. We discussed disagreements until consensus was achieved and asked investigators for further information if data provided in the trial reports were insufficient.

\section{Assessment of risk of bias in included studies}

We used criteria and standard methods of the Cochrane Neonatal Review Group to assess the methodological quality of included trials. Two review authors conducted assessment of risk of bias and resolved disagreements by discussion. We requested additional information from trial authors to clarify methods and results if necessary.

We made explicit judgements about whether studies were at high risk of bias across four domains, according to the criteria suggested in the Cochrane Handbook for Systematic Reviews of Interventions (Higgins 2011).

- Random sequence generation: We categorised the method used to generate the allocation sequence as:

* low risk - any truly random process (e.g. random number table, computer random number generator);

* high risk - any non-random process (e.g. odd or even date of birth, hospital or clinic record number); or

* unclear risk - no or unclear information provided.

- Allocation concealment: We categorised the method used to conceal the allocation sequence as:

* low risk (e.g. telephone or central randomisation, consecutively numbered sealed opaque envelopes);

* high risk - open random allocation (e.g. unsealed or nonopaque envelopes, alternation; date of birth); or

* unclear - no or unclear information provided.

- Blinding: We assessed blinding of participants, clinicians and caregivers and outcome assessors separately for different outcomes and categorised the methods as:

* low risk;

* high risk; or

* unclear risk.

- Incomplete outcome data: We described completeness of data, including attrition and exclusions from analysis for each outcome and reasons for attrition or exclusion, when reported. We assessed whether missing data were balanced across groups or were related to outcomes. When sufficient information was reported or was supplied by trial authors, we planned to reinstate missing data to the analyses. We categorised completeness as:

- low risk: $\leq 10 \%$ missing data;

- high risk: > 10\% missing data; or

- unclear risk: no or unclear information provided.

We assessed the likely magnitude and direction of bias and whether we considered it likely for bias to impact study findings. We planned to explore the impact of the level of bias by performing sensitivity analyses.

\section{Measures of treatment effect}

We analysed treatment effects in individual trials by using Review Manager 5.3 and reported risk ratios (RRs) and risk differences (RDs) for dichotomous data and mean differences (MDs) for continuous data, with respective $95 \%$ confidence intervals (CIs). We determined the number needed to treat for an additional beneficial outcome (NNTB) or an additional harmful outcome (NNTH) for analyses with statistically significant differences among RDs.

\section{Unit of analysis issues}

The unit of analysis was the participating infant in individually randomised trials. For cluster-randomised trials (had we identified any for inclusion), we planned to undertake analyses at the level of the individual while accounting for clustering of data by using methods recommended in the Cochrane Handbook for Systematic Reviews of Interventions (Higgins 2011).

\section{Dealing with missing data}

We requested additional data from trial investigators if data on important outcomes were missing or were reported unclearly. When data were still missing, we examined the impact of this on effect size estimates by performing sensitivity analyses.

\section{Assessment of heterogeneity}

We examined treatment effects in individual trials and heterogeneity between trial results by inspecting forest plots if more than one trial was included in a meta-analysis. We calculated the $\mathrm{I}^{2}$ statistic for each analysis to quantify inconsistency across studies and to describe the percentage of variability in effect estimates that may be due to heterogeneity rather than to sampling error. If we detected moderate or high $\left(\mathrm{I}^{2}>\right.$ $50 \%$ ) heterogeneity, we explored possible causes (e.g. differences in study design, participants or interventions; completeness of outcome assessments) by performing sensitivity analyses.

\section{Assessment of reporting biases}

If more than five trials were included in a meta-analysis, we conducted a funnel plot analysis.

\section{Data synthesis}

We used the fixed-effect model in RevMan 5.1 to perform metaanalysis.

\section{Quality of evidence}

We assessed the quality of evidence for the main comparison at the outcome level by using the Grading of Recommendations Assessment, Development and Evaluation (GRADE) approach 
(Guyatt 2011a), which considers evidence from randomised controlled trials as of high quality that may be downgraded on the basis of consideration of any of five areas.

- Design (risk of bias).

- Consistency across studies.

- Directness of the evidence.

- Precision of estimates.

- Presence of publication bias.

The GRADE approach is used to assess the quality of a body of evidence according to four grades (Schünemann 2013).

- High: We are very confident that the true effect lies close to the estimate of effect.

- Moderate: We are moderately confident in the effect estimate: The true effect is likely to be close to the estimate of effect but may be substantially different.

- Low: Our confidence in the effect estimate is limited: The true effect may be substantially different from the estimate of effect.

- Very low: We have very little confidence in the effect estimate: The true effect is likely to be substantially different from the estimate of effect.

Two review authors assessed independently the quality of the evidence for outcomes identified as critical or important for clinical decision making (growth, development).

In cases for which we considered risk of bias to arise from inadequate concealment of allocation, randomised assignment, complete follow-up or blinded outcome assessment, to reduce our confidence in the effect estimates, we downgraded the quality of evidence accordingly (Guyatt 2011b). We evaluated consistency on the basis of similarity of point estimates, extent of overlap of confidence intervals and statistical criteria, including measurement of heterogeneity $\left(I^{2}\right)$. We downgraded the quality of evidence when inconsistency across study results was large and unexplained (i.e. some studies suggested important benefit, and others no effect or harm with no explanation) (Guyatt 2011c). We assessed precision accordingly with the 95\% confidence interval $(\mathrm{Cl})$ around the pooled estimation (Guyatt 2011d). When trials were conducted in populations other than the target population, we downgraded the quality of evidence because of indirectness (Guyatt 2011e).

We entered data (pooled estimates of effects and 95\% Cls) and explicit judgements for each of the above aspects assessed into the Guideline Development Tool, the software used to create 'Summary of findings (SoF)' tables (GRADEpro 2008). We explained our assessment of study characteristics in footnotes in the SoF table.

\section{Subgroup analysis and investigation of heterogeneity}

We prespecified the following subgroup analyses.

- Very preterm (<32 weeks' gestation) or VLBW $(<1500 \mathrm{~g})$ infants (vs infants at 32 to 36 weeks' gestation or birth weight 1500 to $2499 \mathrm{~g})$.

- Infants who were small for gestational age $(<10$ th percentile for weight) at hospital discharge (vs infants $\geq 10$ th percentile).

- Infants with chronic lung disease receiving supplemental oxygen therapy at hospital discharge (vs infants without chronic lung disease).

\section{RES U L T S}

\section{Description of studies}

We identified two potentially eligible study reports. We included one new trial (Roggero 2011). We have not yet been able to obtain the full article reporting a potentially eligible trial and have categorised this as a 'study awaiting classification' (Ekcharoen 2015). See Figure 1. 
Figure 1. Study flow diagram: review update.

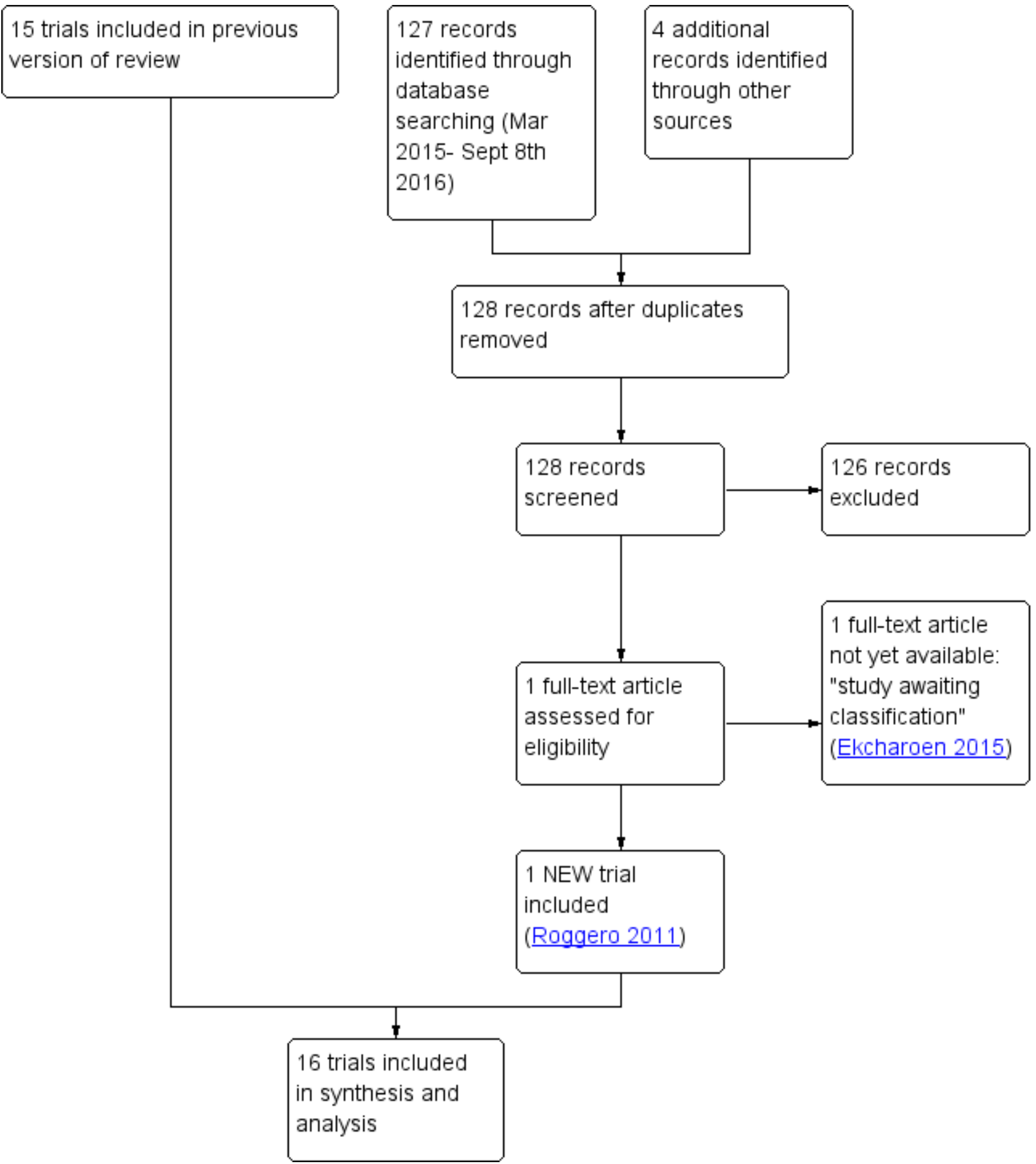

\section{Included studies}

In total, we identified 16 trials that fulfil review eligibility criteria (Agosti 2003; Atkinson 1999; Atkinson 2004; Carver 2001; Cooke 2001; De Curtis 2002; Jeon 2011; Koo 2006; Litmanovitz 2004; Lucas 1992; Lucas 2001; Peng 2004; Picaud 2005; Roggero 2011; Roggero 2012; Taroni 2009). See Characteristics of included studies.

\section{Participants}

Trials were undertaken within the past 20 years by investigators attached to perinatal centres in Europe, North America and the Middle East. In total, 1251 infants participated in these trials (range 20 to 229)

Most trials specified a maximum birth weight as the primary eligibility criterion. 
- 1500 g: Agosti 2003; Litmanovitz 2004; Jeon 2011; Taroni 2009.

- 1750 g: Cooke 2001; De Curtis 2002; Lucas 2001; Picaud 2005.

- 1800 g: Atkinson 1999; Carver 2001.

- 1850 g: Lucas 1992; Peng 2004.

Four trials specified gestational age as an eligibility criterion.

- <35 weeks: Koo 2006.

- <37 weeks: Atkinson 2004; Roggero 2011; Roggero 2012.

Three trials specifically recruited participants who were small for gestational age.

- Birth weight < 5th percentile: Atkinson 2004.

- Birth weight < 10th percentile: Taroni 2009; Roggero 2012.

Although most reports of the other trials did not specify intrauterine or postnatal growth restriction as an exclusion criterion, it appears that very few participants in the trials were small for gestational age at birth or enrolment. Generally, infants with additional problems at discharge, particularly those with inadequate independent oral feeding or receipt of supplemental oxygen secondary to chronic lung disease, were not eligible to participate.

\section{Interventions}

Postdischarge formula versus standard term formula (Comparison 1)

Eleven trials ( $N=885)$ : Atkinson 1999; Atkinson 2004; Carver 2001; De Curtis 2002; Koo 2006; Litmanovitz 2004; Lucas 1992; Lucas 2001; Roggero 2011; Roggero 2012; Taroni 2009.

\section{Preterm formula versus standard term formula (Comparison 2)}

Five trials (N = 366): Agosti 2003; Cooke 2001; Jeon 2011; Peng 2004; Picaud 2005.

\section{Figure 2. Risk of bias graph: review authors' judgements about each risk of bias item presented as percentages across all included studies.}

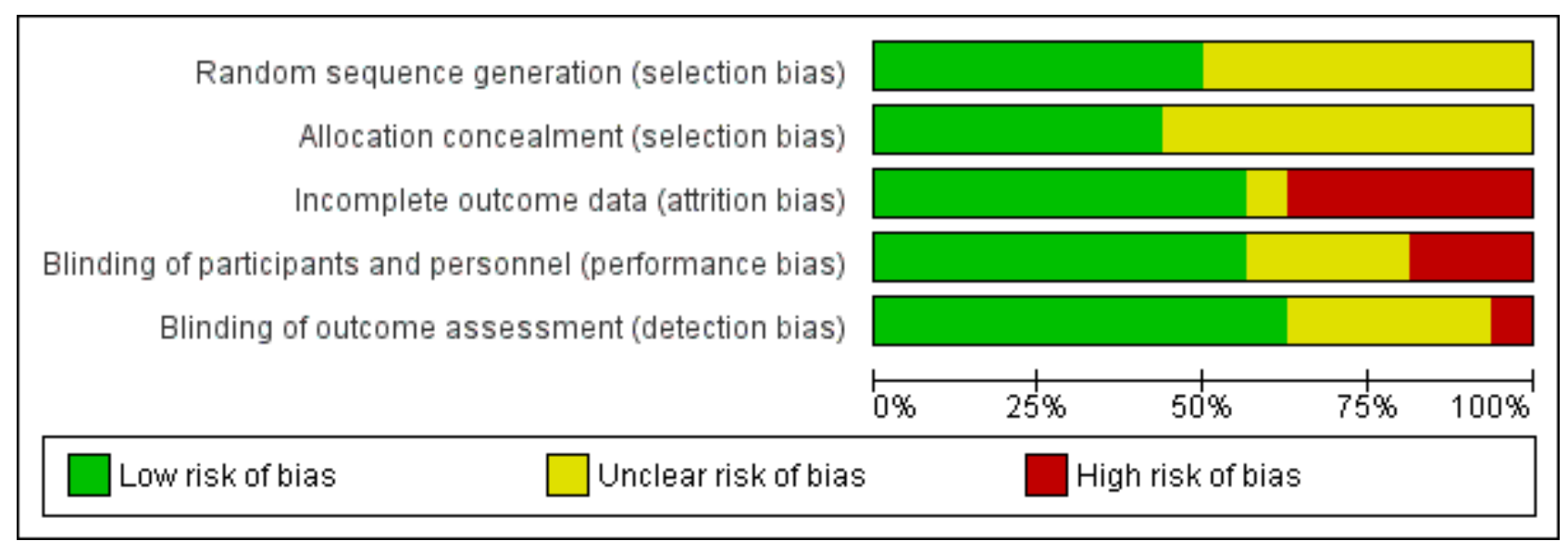

\section{Allocation}

In eight trials (Atkinson 1999; Atkinson 2004; Cooke 2001; Koo 2006; Lucas 2001; Picaud 2005; Roggero 2011; Roggero 2012), the method of randomisation described was likely to ensure blinding of allocation. In the other trials, it is not clear whether allocation concealment was adequate. In one of these trials, substantial between-group differences in baseline demographic
All participating infants were fed ad libitum. These feeds were intended to be the principal source of milk for a range of periods post term (or post hospital discharge).

- One month: Taroni 2009.

- Two months: De Curtis 2002; Picaud 2005.

- Three months: Agosti 2003; Jeon 2011.

- Six months: Cooke 2001; Litmanovitz 2004; Peng 2004; Roggero 2011; Roggero 2012.

- Nine months: Lucas 1992; Lucas 2001.

- Up to 12 months: Atkinson 1999; Atkinson 2004; Carver 2001; Koo 2006.

\section{Outcomes}

The main outcomes assessed were growth parameters (weight, length and occipitofrontal head circumference) assessed up to 12 to 18 months' corrected age. Three trials assessed neurodevelopmental outcomes at 18 months using Bayley Scales of Infant Development II (Cooke 2001; Jeon 2011; Lucas 2001). One trial used Griffiths' Developmental Scales at six, nine and 12 months' corrected age (Agosti 2003).

\section{Excluded studies}

We excluded nine studies (Amesz 2010; Bernbaum 1989; Bhatia 1991; Brunton 1998; Chan 1994; Cooper 1985; Friel 1993; Lapillonne 2004; Wheeler 1996) and listed reasons for exclusion in the Characteristics of excluded studies table.

\section{Risk of bias in included studies}

Trials were of variable methodological quality (Figure 2). 


\section{Blinding}

Most trials blinded families to the type of milk that the infant received. In three trials (Agosti 2003; Jeon 2011; Peng 2004), it is likely that families were aware of which type of milk their infant had been allocated to receive. It is unclear whether blinding was satisfactory in another four trials (Litmanovitz 2004; Roggero 2011; Roggero 2012; Taroni 2009).

Most trials blinded outcome assessors and investigators to the type of milk that the infant received, but in five trials (Jeon 2011; Litmanovitz 2004; Roggero 2011; Roggero 2012; Taroni 2009), it is unclear whether blinding was satisfactory. In one trial (Peng 2004), physicians were unblinded.

\section{Incomplete outcome data}

Eleven trials (Atkinson 2004; Cooke 2001; De Curtis 2002; Jeon 2011; Litmanovitz 2004; Lucas 1992; Lucas 2001; Peng 2004; Roggero 2011; Roggero 2012; Taroni 2009) achieved complete or nearcomplete (> 90\%) assessment. In two other trials (Atkinson 1999; Koo 2006), 75\% of infants underwent outcome assessments at latest follow-up. In another two trials (Agosti 2003; Carver 2001), less than $50 \%$ of infants completed the planned 12 -month followup assessment. In Picaud 2005, loss to follow-up by 12 months in the control group was substantial (35\%) and was greater than in the intervention group (9\%).

\section{Effects of interventions}

See: Summary of findings for the main comparison Postdischarge formula compared with standard term formula for preterm infants after hospital discharge; Summary of findings 2 Preterm formula compared with standard term formula for preterm infants after hospital discharge

\section{Postdischarge formula versus standard term formula (Comparison 1)}

\section{Growth (Outcomes 1.1 to 1.4)}

Lucas 1992 detected no statistically significantly differences in weight, length or head circumference at the end of intervention and follow-up periods (nine months' corrected age).

Atkinson 1999 reported that infants who received postdischarge formula were statistically significantly heavier at six, nine and 12 months' corrected age, and researchers noted no statistically significant differences in length or head circumference.

Carver 2001 detected no statistically significant differences in weight, length or head circumference at six and 12 months' corrected age. Loss to follow-up during the trial was substantial, and as the published report does not state how many infants were assessed at various time points, we could not use data to calculate mean differences.

Lucas 2001 reported that at completion of the intervention period (nine months' corrected age), weight and length were statistically significantly greater among infants who received postdischarge formula but noted no statistically significant differences in head circumference. At 18 months, results showed no statistically significant differences in weight or head circumference. The group of infants who received postdischarge formula remained statistically significantly longer on average than infants in the control group (MD 9.0, 95\% Cl 0.3 to $17.7 \mathrm{~mm}$ ).

De Curtis 2002 found no statistically significant differences in rate of gain of weight, length or head circumference during the two-month trial period.

Atkinson 2004 reported no statistically significant differences in rate of gain of weight, length or head circumference up to 12 months' corrected age (growth data reported as $z$ scores).

Litmanovitz 2004 noted no statistically significant differences in weight, length or head circumference at six months' corrected age.

Koo 2006 reported that mean weight, head circumference and length were less in the nutrient-enriched formula group at six, nine and 12 months after hospital discharge.

Taroni 2009 found no statistically significant differences in weight, length or head circumference at one month corrected age.

Roggero 2011 reported no statistically significant differences in weight, length or head circumference at three, six or 12 months' corrected age.

Roggero 2012 noted no statistically significant differences in weight, length or head circumference at three, six or 12 months' corrected age.

\section{Meta-analyses of growth data}

- Weight (Outcome 1.2; Figure 3): Meta-analyses detected no statistically significant differences in weight at three to four and six months' corrected age. At nine months, meta-analysis of data from four trials (Atkinson 1999; Koo 2006; Lucas 1992; Lucas 2001) indicated that infants in the postdischarge formula group were heavier (weighted mean difference (WMD) 244, 95\% Cl 17 to $471 \mathrm{~g}$ ). At 12 -month follow-up, results showed no statistically significant differences. 
Figure 3. Forest plot of comparison: 1 Postdischarge formula versus standard term formula, outcome: 1.2 Weight (grams).

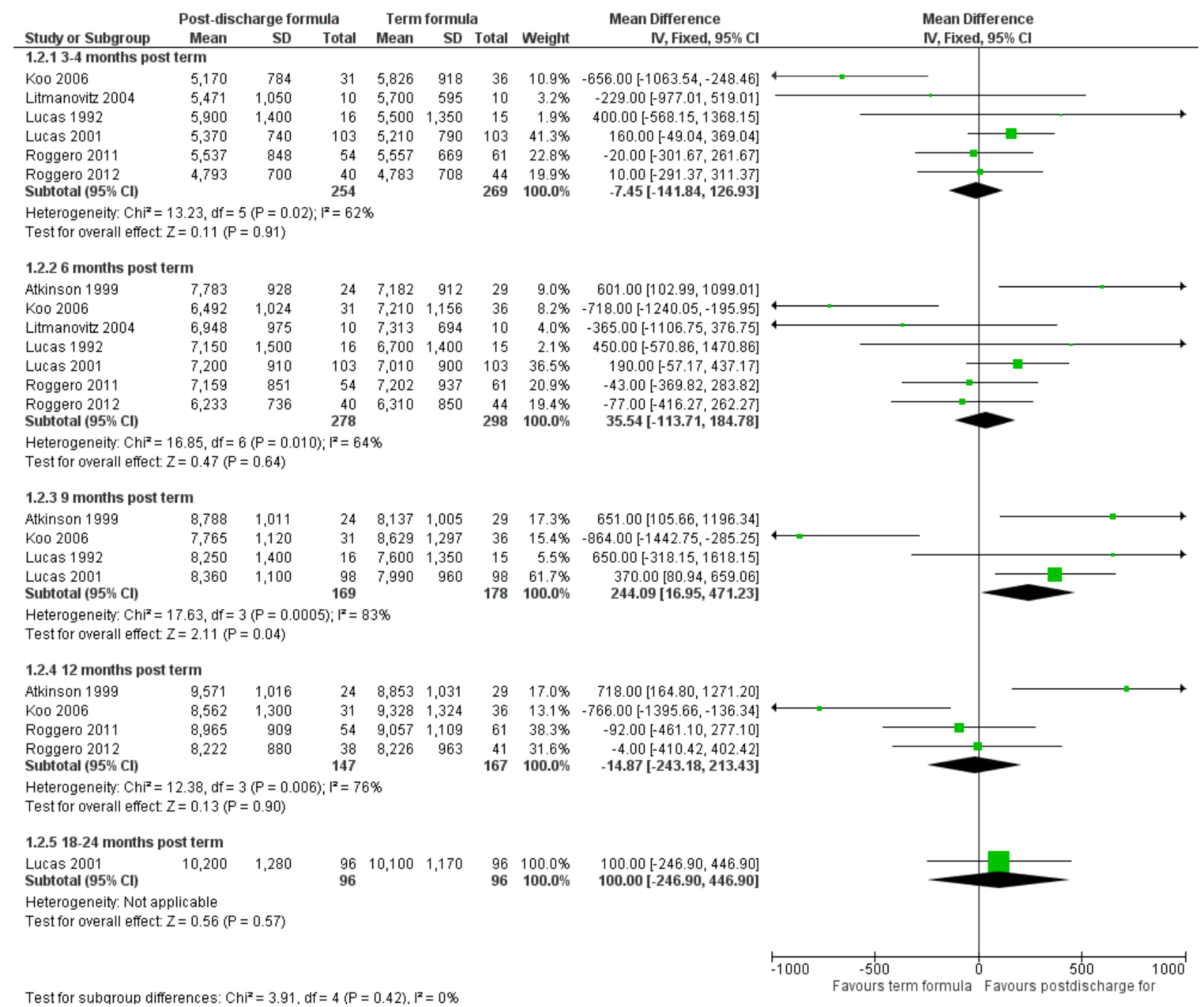

- Length (Outcome 1.3; Figure 4): Meta-analyses detected no statistically significant differences in weight at three to four and six months' corrected age. At nine months, meta-analysis of data from four trials (Atkinson 1999; Koo 2006; Lucas 1992; Lucas
2001) indicated that infants in the postdischarge formula group were longer (WMD 7.3, 95\% Cl 1.8 to $12.9 \mathrm{~mm}$ ). At 12-month follow-up, results showed no statistically significant differences. 
Figure 4. Forest plot of comparison: 1 Postdischarge formula versus standard term formula, outcome: 1.3 Crownheel length $(\mathrm{mm})$.

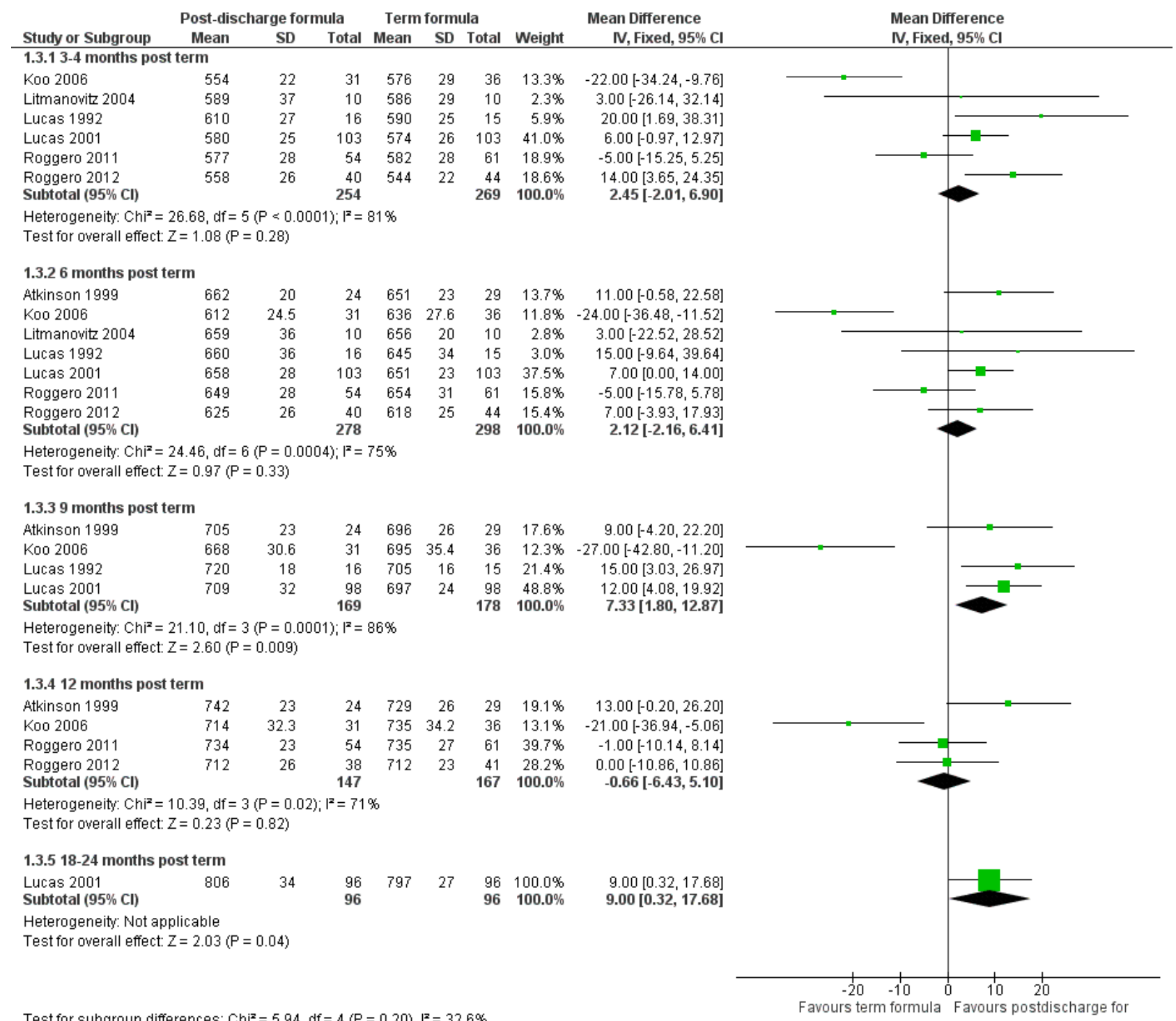

- Head circumference (Outcome 1.4; Figure 5): Meta-analyses detected no statistically significant differences at three to four, six, nine or 12 months. 
Figure 5. Forest plot of comparison: 1 Postdischarge formula versus standard term formula, outcome: 1.4 Head circumference $(\mathbf{m m})$.

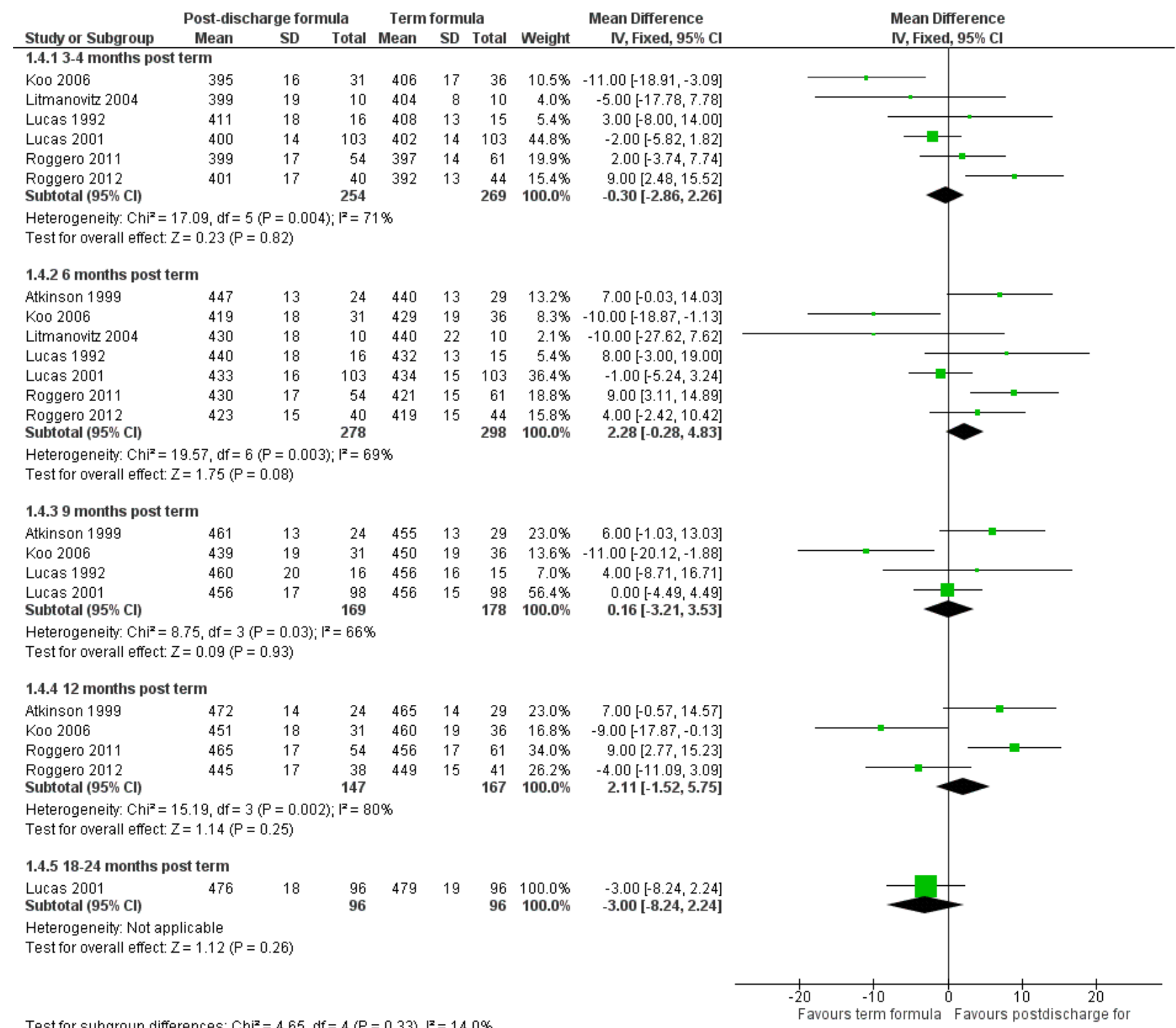

All meta-analyses showed substantial statistical heterogeneity $\left(\mathrm{I}^{2}>\right.$ $50 \%)$.

\section{Development (Outcome 1.5)}

Lucas 2001 did not detect a statistically significant difference in the Bayley Scales Mental or Psychomotor Development Index at 18 months' corrected age. None of the included trials assessed later cognitive and educational outcomes.

\section{Feed intolerance}

Only one trial assessed this outcome (Lucas 1992) and reported no statistically significant difference in the mean number of vomits or possets per day. None of the participating infants ceased taking a study formula because of feed intolerance.

\section{Bone mineralisation (Outcome 1.6)}

Atkinson 2004 found no statistically significant differences in bone mineral content assessed at 12 months' corrected age (numerical data not available).

De Curtis 2002 reported no statistically significant differences in bone mineral content nor in bone area at the end of the two-month study period.

Koo 2006 reported that at the end of the 12 -month study period, infants who received nutrient-enriched formula had statistically significantly lower bone mass (measured by dual-energy X-ray absorptiometry). Investigators presented data in graphs only, and data could not be extracted or obtained for calculation of mean differences.

Lucas 1992 assessed bone width and bone mineral content of the radius at nine months' corrected age. Bone width was not 
statistically significantly different between groups. Bone mineral content was statistically significantly greater in the group of infants who received the postdischarge formula: mean difference $20.6,95 \%$ $\mathrm{Cl} 7.8$ to $33.4 \mathrm{mg} / \mathrm{cm}$.

Litmanovitz 2004 found no statistically significant differences in bone strength assessed as 'bone speed of sound' on measurement with ultrasonography, nor in serum levels of bone-specific alkaline phosphatase, at six months' corrected age.

No trials assessed the effect of the intervention on clinical or radiological evidence of rickets.

\section{Blood pressure on long-term follow-up}

No included trials performed this assessment.

\section{Body mass index on long-term follow-up}

No included trials performed this assessment.

\section{Subgroup analyses}

- VLBW or very preterm infants: Two trials (Litmanovitz 2004; Taroni 2009) recruited exclusively VLBW infants. As described above, investigators found no statistically significant differences in weight, length or head circumference, nor in measures of bone mineralisation, up to six months' corrected age.

- Infants who remain small for gestational age at hospital discharge: Three trials (Atkinson 2004; Roggero 2012; Taroni 2009) recruited infants who were growth-restricted at birth. These trials detected no statistically significant effects on weight up to 12 months' corrected age, but meta-analyses of data from the two trials that undertook follow-up at six months (Atkinson 2004; Roggero 2012) revealed statistically significant effects on crown-heel length (WMD 8.88, 95\% Cl 0.94 to $16.83 \mathrm{~mm}$ ) and on head circumference (WMD 5.36, 95\% Cl 0.62 to $10.11 \mathrm{~mm}$ ).

- Infants with chronic lung disease requiring home supplemental oxygen therapy: No trials exclusively recruited infants with chronic lung disease. Subgroup data were not available.

\section{Preterm formula versus standard term formula (Comparison} 2)

\section{Growth (Outcomes 2.1-2.4)}

Cooke 2001 found no statistically significant differences in rate of weight gain during the trial period. Researchers presented data in graphs only, and data could not be extracted or obtained for calculation of the mean difference. At 18 months' corrected age, the nutrient-enriched formula group was statistically significantly heavier than the control group (MD 500, 95\% Cl 26 to 974 g), but investigators noted no statistically significant differences in length or head circumference.

Agosti 2003 reported no statistically significant differences in mean weight, length or head circumference at four, six and 12 months after hospital discharge.

Peng 2004 noted no statistically significant differences in mean weight, length or head circumference at monthly intervals up to six months' corrected age.

Picaud 2005 observed no statistically significant differences in rate of gain of weight, length or head circumference during the first four months of the trial period and no statistically significant differences in weight, length or head circumference between groups at four months. At 12 months post discharge, infants in the preterm formula group were heavier (MD 1007, 95\% Cl 211 to $1803 \mathrm{~g}$ ) (Outcome 2.2), were longer (MD 27,95\% $\mathrm{Cl} 2$ to $52 \mathrm{~mm}$ ) (Outcome 2.3) and had larger head circumference (MD $12,95 \% \mathrm{Cl} 0.2$ to 24 $\mathrm{mm}$ ) (Outcome 2.4) than control infants. However, loss to follow-up by 12 months was substantial in the control group (35\%) and was greater than that reported for the intervention group (9\%).

Jeon 2011 found no statistically significant differences in mean weight, length or head circumference at three, 12 and 18 months after hospital discharge.

\section{Meta-analyses of growth data}

- Weight (Outcome 2.2; Figure 6): Meta-analysis of data from four trials (Agosti 2003; Cooke 2001; Jeon 2011; Picaud 2005) showed statistically significantly higher weight in the preterm formula group at 12 months' corrected age (WMD 540, 95\% Cl 255 to 824 g). Meta-analysis of data from two trials (Cooke 2001; Jeon 2011) revealed statistically significantly higher weight in the preterm formula group at 18 months (WMD $491,95 \% \mathrm{Cl} 142$ to $839 \mathrm{~g}$ ) (Outcome 2.2). 
Figure 6. Forest plot of comparison: 2 Preterm formula versus standard term formula, outcome: 2.2 Weight (grams).

\begin{tabular}{lcrrrrrrr} 
& \multicolumn{2}{c}{ Preterm formula } & \multicolumn{3}{c}{ Term formula } & \multicolumn{2}{c}{ Mean Difference } \\
Study or Subgroup & Mean & SD & Total & Mean & SD & Total & Weight & IV, Fixed, 95\% Cl \\
\hline 2.2.13-4 months post term & & & & & & & \\
Jeon 2011 & 6,030 & 973 & 30 & 6,219 & 864 & 29 & $53.0 \%$ & $-189.00[-658.16,280.16]$ \\
Peng 2004 & 6,150 & 1,254 & 16 & 6,100 & 864 & 13 & $19.5 \%$ & $50.00[-723.39,823.39]$ \\
Picaud 2005 & 6,139 & 1,254 & 21 & 5,540 & 863 & 21 & $27.5 \%$ & $599.00[-52.07,1250.07]$ \\
Subtotal (95\% Cl) & & & $\mathbf{6 7}$ & & & $\mathbf{6 3}$ & $\mathbf{1 0 0 . 0} \%$ & $\mathbf{7 4 . 4 1}[-\mathbf{2 6 7 . 1 0}, \mathbf{4 1 5 . 9 3 ]}$
\end{tabular}

Heterogeneity: $\mathrm{Chi}^{2}=3.71, \mathrm{df}=2(\mathrm{P}=0.16) ; \mathrm{I}^{2}=46 \%$

Test for overall effect: $Z=0.43(P=0.67)$

2.2.2 6 months post term

$\begin{array}{lrrrrrrrr}\text { Agosti 2003 } & 7,113 & 825 & 38 & 7,056 & 1,053 & 34 & 29.5 \% & 57.00[-383.55,497.55] \\ \text { Cooke 2001 } & 7,242 & 1,124 & 56 & 7,078 & 935 & 57 & 39.3 \% & 164.00[-217.55,545.55] \\ \text { Jeon 2011 } & 7,644 & 1,013 & 30 & 7,723 & 1,025 & 29 & 21.2 \% & -79.00[-599.16,441.16] \\ \text { Peng 2004 } & 7,100 & 1,013 & 16 & 7,000 & 1,053 & 13 & 10.0 \% & 100.00[-657.64,857.64] \\ \text { Subtotal (95\% Cl) } & & & \mathbf{1 4 0} & & & \mathbf{1 3 3} & \mathbf{1 0 0 . 0 \%} & \mathbf{7 4 . 6 0}[-\mathbf{1 6 4 . 7 3}, \mathbf{3 1 3 . 9 2}]\end{array}$

$\begin{array}{lllll}\text { Subtotal }(95 \% \mathrm{Cl}) & 140 & 133 & 100.0 \% & 74.60[-164.73,313.92]\end{array}$

Heterogeneity: $\mathrm{Ch}^{2}=0.56, \mathrm{df}=3(\mathrm{P}=0.91) ; \mathrm{I}^{2}=0 \%$

Test for overall effect: $Z=0.61(P=0.54)$

2.2.3 9 months post term

$\begin{array}{lllllllll}\text { Jeon } 2011 & 8,848 & 1,211 & 30 & 8,736 & 1,119 & 29 & 100.0 \% & 112.00[-482.69,706.69) \\ \text { Subtotal }(\mathbf{9 5} \% \mathrm{Cl}) & & & \mathbf{3 0} & & & \mathbf{2 9} & \mathbf{1 0 0 . 0} \% & \mathbf{1 1 2 . 0 0}[-\mathbf{4 8 2 . 6 9 , 7 0 6 . 6 9 ]}\end{array}$

Heterogeneity. Not applicable

Test for overall effect: $Z=0.37(P=0.71)$

2.2.4 12 months post term

\begin{tabular}{|c|c|c|c|c|c|c|c|c|}
\hline Agosti 2003 & 9,717 & 1,192 & 31 & 9,256 & 1,146 & 24 & $20.9 \%$ & $461.00[-160.52,1082.52]$ \\
\hline Cooke 2001 & 9,203 & 1,213 & 56 & 8,649 & 943 & 57 & $50.3 \%$ & $554.00[152.92,955.08]$ \\
\hline Jeon 2011 & 9,667 & 1,520 & 30 & 9,444 & 1,260 & 29 & $16.0 \%$ & $223.00[-488.44,934.44]$ \\
\hline Picaud 2005 & 9,486 & 1,310 & 21 & 8,479 & 1,189 & 17 & $12.8 \%$ & $1007.00[211.15,1802.85]$ \\
\hline Subtotal (95\% Cl) & & & 138 & & & 127 & $100.0 \%$ & $539.48[255.03,823.92]$ \\
\hline
\end{tabular}

2.2.5 18 months post term

$\begin{array}{lrrrrrrrr}\text { Cooke 2001 } & 10,400 & 1,400 & 49 & 9,900 & 1,000 & 54 & 54.1 \% & 500.00[25.87,974.13] \\ \text { Jeon 2011 } & 10,713 & 895 & 30 & 10,233 & 1,106 & 29 & 45.9 \% & 480.00[-34.40,994.40] \\ \text { Subtotal (95\% Cl) } & & & \mathbf{7 9} & & & \mathbf{8 3} & \mathbf{1 0 0 . 0} \% & \mathbf{4 9 0 . 8 1 [ 1 4 2 . 1 9 , 8 3 9 . 4 4 ]}\end{array}$

Heterogeneity: $\mathrm{Chi}^{2}=0.00, \mathrm{df}=1(\mathrm{P}=0.96)^{2} \mathrm{i}^{2}=0 \%$

Test for overall effect: $Z=2.76(P=0.006)$

Test for subqroup differences: $\mathrm{Chi}^{2}=9.07, \mathrm{df}=4(\mathrm{P}=0.06), \mathrm{I}^{2}=55.9 \%$

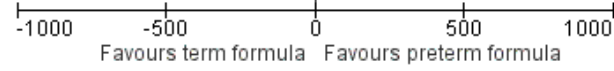

- Length (Outcome 2.3; Figure 7): Meta-analysis of data from three trials (Agosti 2003; Jeon 2011; Picaud 2005) showed no statistically significant difference at 12 months' corrected age (WMD 5.1, 95\% Cl -4.2 to $14.5 \mathrm{~mm}$ ). Meta-analysis of data

from two trials (Cooke 2001; Jeon 2011) revealed statistically significantly longer crown-heel length in the preterm formula group at 18 months (WMD $11,95 \% \mathrm{Cl} 2$ to $20 \mathrm{~mm}$ ). 
Figure 7. Forest plot of comparison: 2 Preterm formula versus standard term formula, outcome: 2.3 Crown-heel length (mm).

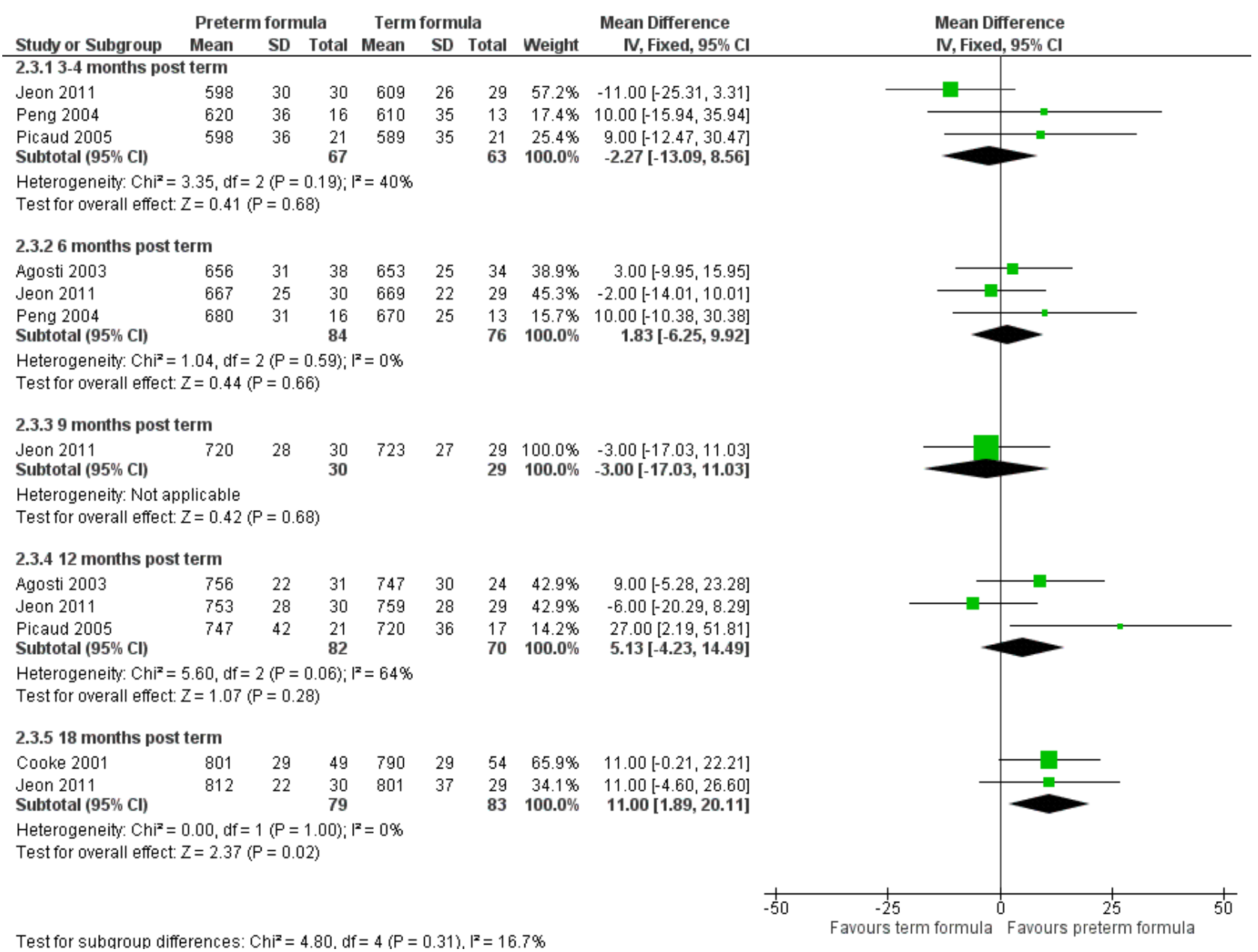

- Head circumference (Outcome 2.4; Figure 8): Meta-analysis of data from three trials (Agosti 2003; Jeon 2011; Picaud 2005) showed a statistically significantly larger head circumference in the preterm formula group at 12 months' corrected age (WMD
$6.1,95 \% \mathrm{Cl} 1.1$ to $11.1 \mathrm{~mm}$ ). Meta-analysis of data from two trials (Cooke 2001; Jeon 2011) revealed a statistically significantly larger head circumference in the preterm formula group at 18 months (WMD 5.4, 95\% Cl 0.7 to $10.1 \mathrm{~mm}$ ). 
Figure 8. Forest plot of comparison: 2 Preterm formula versus standard term formula, outcome: 2.4 Head circumference (mm).

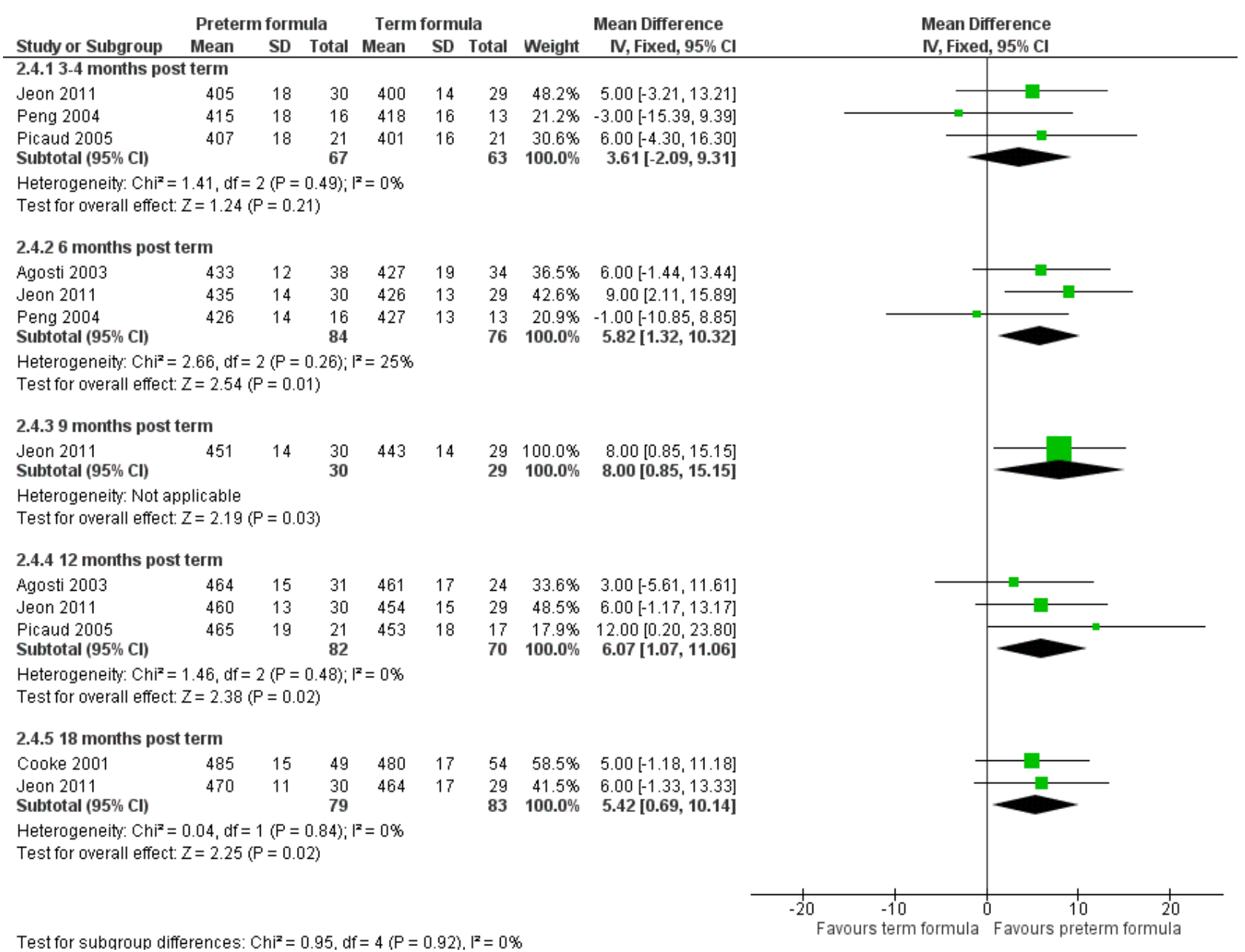

\section{Development (Outcome 2.5)}

Neither Cooke 2001 nor Jeon 2011 nor a meta-analysis of data from both trials detected a statistically significant difference in the Bayley Scales Mental Development Index (WMD -1.4, 95\% Cl -6.2 to 3.4) or in the Psychomotor Development Index (WMD -1.1, $95 \% \mathrm{Cl}-4.2$ to 1.93 ). Agosti 2003 noted no statistically significant differences in Griffiths' Developmental Scale evaluations at six, nine and 12 months' corrected age (numerical data not available from report nor from trialists).

\section{Feed intolerance}

No included trials performed this assessment.

\section{Bone mineralisation}

Cooke 2001 assessed body composition with dual-energy X-ray absorptiometry at six and 12 months' corrected age and noted no statistically significant differences in bone area, bone mineral mass or bone mineral density measurements between groups. In the published report, all data were presented in graphs and could not be extracted for estimation of mean differences. Investigators also reported that they found no statistically significant differences in serum phosphorus, calcium and alkaline phosphatase levels measured at intervals during the study period (up to six months post term). These data were presented mainly in graphs and could not be extracted for estimation of mean differences.

\section{Blood pressure on long-term follow-up}

No included trials performed this assessment.

\section{Body mass index on long-term follow-up}

No included trials performed this assessment.

\section{Subgroup analyses}

- VLBW or very preterm infants: Two trials (Agosti 2003; Jeon 2011) exclusively recruited VLBW infants. See details of findings described above. Subgroup data from the other trials were not available.

- Infants who remain small for gestational age at hospital discharge: Subgroup data were not available.

- Infants with chronic lung disease requiring home supplemental oxygen therapy: Subgroup data were not available. 


\section{DISCUSSION}

\section{Summary of main results}

Data from 11 randomised controlled trials with a total of 885 participants provided no evidence that feeding postdischarge formula ( $74 \mathrm{kcal} / 100 \mathrm{~mL}$ ) versus standard term formula ( 67 $\mathrm{kcal} / 100 \mathrm{~mL}$ ) to preterm infants after hospital discharge affects growth parameters up to 12 to 18 months post term.

The five trials that examined the effect of feeding preterm formula ( $80 \mathrm{kcal} / 100 \mathrm{~mL}$ ) versus standard term formula provided some evidence of an effect on growth parameters. Meta-analyses showed a weighted mean difference of about $500 \mathrm{~g}$ for weight, $11 \mathrm{~mm}$ for length and 5 to $6 \mathrm{~mm}$ for head circumference at 12 to 18 months post term. It is not yet known whether any of these differences persist through later childhood.

Evidence of the effects of nutrient-enriched formula on longterm development is unclear. The only trial of postdischarge versus term formula conducted to assess developmental outcomes showed no difference in the Bayley Scales Mental or Psychomotor Development Index assessed at 18 months' corrected age (Lucas 2001). Similarly, meta-analyses of data from two trials provided no evidence that feeding preterm versus term formula affects neurodevelopmental outcomes at 18 months' corrected age. Data on longer-term cognitive and educational outcomes are not yet available.

\section{Overall completeness and applicability of evidence}

We identified 11 eligible trials that compared feeding with postdischarge formula versus term formula, but studies generally were small and of variable methodological quality. Quantitative synthesis was limited, as only seven of these trials (Atkinson 1999; Koo 2006; Litmanovitz 2004; Lucas 1992; Lucas 2001; Roggero 2011; Roggero 2012) presented data that could be included in metaanalyses of growth outcomes. Interpretation of meta-analyses was further limited by heterogeneity. The source of heterogeneity is not clear, as these trials were of similar design (intervention given for six to 12 months) and methodological quality (satisfactory processes to ensure allocation concealment and achievement of about $70 \%$ to $80 \%$ follow-up at longer than six months post term). Meta-analyses of data from the five trials that compared preterm formula versus term formula were more complete and revealed no statistical heterogeneity.

Differences in measured effects on growth parameters between postdischarge formula and preterm formula may simply be related to total nutrient content and intake. An additional factor is that whereas postdischarge formula contains about $10 \%$ more calories and $20 \%$ to $25 \%$ more protein and bone minerals than term formula, preterm formula is about $20 \%$ energy-enriched and contains $40 \%$ to $60 \%$ more protein and minerals than term formula. Demand (responsively) fed infants regulate their volume of milk intake relative to its calorie density; therefore, infants in comparison groups may have had similar total energy intake. However, infants fed postdischarge formula would still have received about $10 \%$ more protein and minerals than those fed term formula, but infants fed preterm formula would have received up to about $25 \%$ more protein and minerals than those given term formula. It is possible that protein and mineral intake (per unit of energy) is the key factor in determining catch-up growth rates and, specifically, lean and skeletal growth, in this population of infants.

The applicability of currently available data is limited by the short duration of follow-up reported in clinical trials. No trials planned to undertake or undertook assessment of growth or development beyond 12 to 18 months' corrected age, and some trials reported growth outcomes only up to six months. Similarly, no trials have reported data related to possible adverse metabolic consequences of nutrient supplementation in early infancy, nor to any long-term measures of obesity (such as body mass index (BMI), fat mass) or risk factors for cardiovascular disease (such as elevated blood pressure).

\section{Quality of the evidence}

Interpretation of review findings is limited by methodological weaknesses associated with potential for bias in some trials (Figure 2). Methods used to preserve allocation concealment are uncertain for some trials. Only one trial (Jeon 2011) reported substantial between-group differences in baseline demographics that are likely due to allocation bias. We elected to exclude one arm of this three-arm trial because of substantial differences in mean birth weight, gestational age and proportion of growth-restricted infants. The other methodological limitation apparent in six trials was incomplete outcome assessment (loss to follow-up > 20\%). In most of these trials (Atkinson 1999; Koo 2006; Peng 2004; Picaud 2005), loss to follow-up was less than $30 \%$ and was distributed evenly between intervention and control groups. In two trials (Agosti 2003; Carver 2001), loss to follow-up at 12-month assessment was greater than $50 \%$. However, these trials did not contribute substantially to any meta-analyses.

The GRADE assessment revealed that evidence for key growth outcomes was of moderate quality because of inconsistency (moderate or high heterogeneity in meta-analyses of trials of postdischarge formula vs standard formula; Summary of findings for the main comparison) and imprecision (few trials with low numbers of participants included in meta-analyses of preterm formula vs standard formula; Summary of findings 2).

\section{Potential biases in the review process}

Our main concern with the review process is that findings may be subject to publication and other reporting biases, including greater availability of numerical data for inclusion in meta-analyses from trials that reported statistically significant or clinically important effects (Hopewell 2009). We attempted to minimise this threat by searching the proceedings of major international perinatal conferences to identify trial reports that were not (or were not yet) published in full form in academic journals. However, we cannot be sure whether other trials have been undertaken but not reported, and we remain concerned that such trials are less likely than published trials to have detected statistically significant or clinically important effects. The meta-analyses that we performed did not include sufficient trials to explore the symmetry of funnel plots as a means of identifying possible publication or reporting bias.

\section{AUTHORS' CONCLUSIONS}

\section{Implications for practice}

These findings do not support expert group and consensus recommendations that formula-fed preterm infants should receive 
a postdischarge formula for up to 12 months after discharge from the hospital (Aggett 2006; Bhatia 2005; Carver 2005; Dusick 2003; Griffin 2007; Kleinman 2004). In contrast, available trial data indicate that feeding with 'preterm formula', which generally is licensed and available only for in-hospital use, may increase weight, length and head circumference growth up to 12 to 18 months post term.

Infants who participated in the trials included in this review were fed responsively (on demand), and study findings may not be applicable to infants who cannot feed responsively, for example, because of oro-motor dysmotility or chronic lung disease.

\section{Implications for research}

Follow-up of infants who participated in the trials identified in this review might provide further data on the effect of this intervention on growth through later childhood, specifically, whether final height is affected; on effects on later neurodevelopmental outcomes; and on long-term effects on metabolic or cardiovascular outcomes (Euser 2005; Greer 2007). If additional large randomised controlled trials are undertaken to evaluate the effects of feeding preterm infants with nutrient-enriched formula after hospital discharge, it may be appropriate to include in these research efforts preterm infants who are not able to feed ad libitum after hospital discharge, and who have extra metabolic demands, for example, because of severe growth restriction or chronic lung disease. Trials should aim to assess long-term clinically important outcomes such as final height and body composition and neurodevelopment (including cognitive and educational outcomes).

Further research is needed to determine which specific nutrients (including appropriate energy:protein balance) are key to promoting lean mass and linear growth and to improving developmental outcomes. As a first step, it may be worthwhile to review systematically trials that could not be included in this review because the nutrient-enriched formula examined differed only in protein and mineral content (but not in energy) from standard term formula.

\section{ACKNOWLEDGEMENTS}

We thank Dr Litmanovitz for clarifying aspects of Litmanovitz 2004.

We thank Dr Roggero for kindly providing unpublished data from Roggero 2011 for inclusion in this review.

We thank Yolanda Brosseau and Colleen Ovelman of the Cochrane Neonatal Review Group for help in preparing this updated review.

Editorial support of the Cochrane Neonatal Review Group has been provided with Federal funds from the Eunice Kennedy Shriver National Institute of Child Health and Human Development, National Institutes of Health, Department of Health and Human Services, USA, under Contract No. HHSN275201100016C. 


\section{R E F E R E N C E S}

\section{References to studies included in this review}

Agosti 2003 \{published data only\}

Agosti M, Vegni C, Calciolari G, Marini A, GAMMA Study Group. Post-discharge nutrition of the very low-birthweight infant: interim results of the multicentric GAMMA study. Acta Paediatrica Supplement 2003;91:39-43.

\section{Atkinson 1999 \{published data only\}}

Atkinson SA, Randall-Simpson J, Chang M, Paes B. Randomised trial of feeding nutrient-enriched versus standard formula to premature infants during the first year of life. Pediatric Research 1999;45:276A.

\section{Atkinson 2004 \{published data only\}}

Atkinson SA, Paes B, Saigal S, Hussey T, Lee D. Nutrient-enriched discharge formula compared to standard term formula does not benefit growth, bone mineral accretion or trace element status in preterm small for gestational age (SGA) infants to one year corrected age: an RCT. Pediatric Research 2004;55:383A.

\section{Carver 2001 \{published data only\}}

Carver JD, Wu PY, Hall RT, Ziegler EE, Sosa R, Jacobs J, et al. Growth of preterm infants fed nutrient-enriched or term formula after hospital discharge. Pediatrics 2001;107:683-9.

\section{Cooke 2001 \{published data only\}}

* Cooke RJ, Embleton ND, Griffin IJ, Wells JC, McCormick KP. Feeding preterm infants after hospital discharge: growth and development at 18 months of age. Pediatric Research 2001;49:719-22.

Cooke RJ, Griffin IJ, McCormick K. Adiposity is not altered in preterm infants fed with a nutrient-enriched formula after hospital discharge. Pediatric Research 2010;67:660-4. [PUBMED: 20216105]

Cooke RJ, Griffin IJ, McCormick K, Wells JC, Smith JS, Robinson SJ, Leighton M. Feeding preterm infants after hospital discharge: effect of dietary manipulation on nutrient intake and growth. Pediatric Research 1998;43:355-60.

Cooke RJ, McCormick K, Griffin IJ, Embleton N, Faulkner K, Wells JC, et al. Feeding preterm infants after hospital discharge: effect of diet on body composition. Pediatric Research 1999;46:461-4

\section{De Curtis 2002 \{published data only\}}

De Curtis M, Pieltain C, Rigo J. Body composition in preterm infants fed standard term or enriched formula after hospital discharge. European Journal of Nutrition 2002;41:177-82.

\section{Jeon 2011 \{published data only\}}

Jeon GW, Jung YJ, Koh SY, Lee YK, Kim KA, Shin SM, et al. Preterm infants fed nutrient-enriched formula until six months show improved growth and development. Pediatrics International 2011;53:683-8. [PUBMED: 21342352]
Koo 2006 \{published data only\}

Koo WW, Hockman EM. Posthospital discharge feeding for preterm infants: effects of standard compared with enriched milk formula on growth, bone mass, and body composition. American Journal of Clinical Nutrition 2006;84:1357-64.

\section{Litmanovitz 2004 \{published data only\}}

* Litmanovitz I, Dolfin T, Arnon S, Bauer S, Regev R, ShainkinKestenbaum $\mathrm{R}$, et al. Bone strength and growth of preterm infants fed nutrient-enriched or term formula after hospital discharge. Pediatric Research 2004;55:274A.

Litmanovitz I, Eliakim A, Arnon S, Regev R, Bauer S, ShainkinKestenbaum $\mathrm{R}$, et al. Enriched post-discharge formula versus term formula for bone strength in very low birth weight infants: a longitudinal pilot study. Journal of Perinatal Medicine 2007;35:431-5. [PUBMED: 17605597]

Lucas 1992 \{published data only\}

Bishop NJ, King FJ, Lucas A. Increased bone mineral content of preterm infants fed with a nutrient enriched formula after discharge from hospital. Archives of Disease in Childhood 1993;68:573-8

* Lucas A, Bishop NJ, King FJ, Cole TJ. Randomised trial of nutrition for preterm infants after discharge. Archives of Disease in Childhood 1992;67:324-7.

\section{Lucas 2001 \{published data only\}}

Lucas A, Fewtrell MS, Morley R, Singhal A, Abbott RA, Isaacs E, et al. Randomized trial of nutrient-enriched formula versus standard formula for postdischarge preterm infants. Pediatrics 2001;108:703-11.

\section{Peng 2004 \{published data only\}}

Peng CC, Hsu CH, Kao HA, Hung HY, Chang JH. Feeding with premature or infant formula in premature infants after discharge: comparison of growth and nutrition status. Acta Paediatrica Taiwanica 2004;45:151-7. [PUBMED: 15493734]

\section{Picaud 2005 \{published data only\}}

Picaud JC, Plan O, Pidoux O, Reygrobellet B. Chapuis F, Salle BL, et al. Effect of post-discharge nutrition on growth and whole body mineralization in very low birth weight (VLBW) infants. Pediatric Academic Societies Conference Proceedings. PAS2005:57:1326.

Roggero 2011 \{published data only (unpublished sought but not used)\}

Gianni ML, Roggero P, Amato O, Picciolini O, Piemontese P, Liotto N, et al. Randomized outcome trial of nutrient-enriched formula and neurodevelopment outcome in preterm infants. BMC Pediatrics 2014;14:74. [PUBMED: 24645671]

* Roggero P, Gianni ML, Amato O, Liotto N, Morlacchi L, Orsi $A$, et al. Growth and fat-free mass gain in preterm infants after discharge: a randomized controlled trial. Pediatrics 2012;130:e1215-21. [PUBMED: 23109680] 


\section{Roggero 2012 \{published data only\}}

Roggero $P$, Giannì ML, Liotto N, Taroni F, Morniroli D, Mosca F. Small for gestational age preterm infants: nutritional strategies and quality of growth after discharge. Journal of MaternalFetal and Neonatal Medicine 2011;24(Suppl 1):144-6. [PUBMED: 21888510]

\section{Taroni 2009 \{published data only\}}

Taroni E, Liotto N, Orsi A, Piemontese P, Amato O, Morlacchi L, et al. Quality of post-discharge growth in small for gestational age preterm infants: an explorative study [Qualita della crescita post-dimissione in prematuri nati piccoli per eta gestazionale: studio esplorativo]. La Pediatria Medica e Chirurgica 2009;31:121-5. [PUBMED: 19739491]

\section{References to studies excluded from this review}

\section{Amesz 2010 \{published data only\}}

Amesz EM, Schaafsma A, Cranendonk A, Lafeber HN. Optimal growth and lower fat mass in preterm infants fed a proteinenriched postdischarge formula. Journal of Pediatric Gastroenterology and Nutrition 2010;50:200-7. [PUBMED: 19881394]

\section{Bernbaum 1989 \{published data only\}}

Bernbaum JC, Sasanow SR, Churella HR, Daft A. Growth and metabolic response of premature infants fed whey- or casein-dominant formulas after hospital discharge. Journal of Pediatrics 1989;115:652-6. [PUBMED: 2795362]

\section{Bhatia 1991 \{published data only\}}

Bhatia J, Rassin DK. Feeding the premature infant after hospital discharge: growth and biochemical responses. Journal of Pediatrics 1991;118:515-9.

\section{Brunton 1998 \{published data only\}}

Brunton JA, Saigal S, Atkinson SA. Growth and body composition in infants with bronchopulmonary dysplasia up to 3 months corrected age: a randomized trial of a high-energy nutrient-enriched formula fed after hospital discharge. Journal of Pediatrics 1988;133:340-5.

\section{Chan 1994 \{published data only\}}

Chan GM. Growth and bone mineral status of discharged very low birth weight infants fed different formulas or human milk. Journal of Pediatrics 1993;123:439-43.

Chan GM, Borschel MW, Jacobs JR. Effects of human milk or formula feeding on the growth, behavior, and protein status of preterm infants discharged from the newborn intensive care unit. American Journal of Clinical Nutrition 1994;60:710-6.

\section{Cooper 1985 \{published data only\}}

Cooper PA, Rothberg AD. Feeding of very-low-birth-weight infants with special formula - continued use beyond $2000 \mathrm{~g}$ and effects on growth to 1 year. South African Medical Journal 1985;67:716-8.

\section{Friel 1993 \{published data only\}}

Friel JK, Andrews WL, Matthew D, McKim E, French S, Long DR. Improved growth of very low birthweight infants. Nutrition Research 1993;13:611-20.

\section{Lapillonne 2004 \{published data only\}}

Lapillonne A, Salle BL, Glorieux FH, Claris O. Bone mineralization and growth are enhanced in preterm infants fed an isocaloric, nutrient-enriched preterm formula through term. American Journal of Clinical Nutrition 2004;80(6):1595-603. [PUBMED: 15585774$]$

\section{Wheeler 1996 \{published data only\}}

Wheeler RE, Hall RT. Feeding of premature infant formula after hospital discharge of infants weighing less than 1800 grams at birth. Journal of Perinatology 1996;16:111-6.

\section{References to studies awaiting assessment}

Ekcharoen 2015 \{published data only\}

Ekcharoen C, Tantibhaedhyangkul R. Comparing growth rates after hospital discharge of preterm infants fed with either postdischarge formula or high-protein, medium-chain triglyceride containing formula. Journal of the Medical Association of Thailand 2015;98(12):1179-86. [PUBMED: 27004302]

\section{Additional references}

\section{Aggett 2006}

Aggett PJ, Agostoni C, Axelsson I, De Curtis M, Goulet O, Hernell $O$, et al. Feeding preterm infants after hospital discharge: a commentary by the ESPGHAN Committee on Nutrition. Journal of Pediatric Gastroenterology and Nutrition 2006;42:596-603. [PUBMED: 16707992]

\section{Bhatia 2005}

Bhatia J. Post-discharge nutrition of preterm infants. Journal of Perinatology 2005;25 Suppl 2:S15-6; discussion S17-8. [PUBMED: 15861162]

\section{Bracewell 2008}

Bracewell MA, Hennessy EM, Wolke D, Marlow N. The EPICure study: growth and blood pressure at 6 years of age following extremely preterm birth. Archives of Disease in Childhood. Fetal and Neonatal Edition 2008;93:F108-14. [PUBMED: 17660214]

\section{Carver 2005}

Carver JD. Nutrition for preterm infants after hospital discharge. Advances in Pediatrics 2005;52:23-47. [PUBMED: 16124335]

\section{Clark 2003}

Clark RH, Thomas P, Peabody J. Extrauterine growth restriction remains a serious problem in prematurely born neonates. Pediatrics 2003;111:986-90.

\section{Cooke 2003}

Cooke RWI, Foulder-Hughes L. Growth impairment in the very preterm and cognitive and motor performance at 7 years. Archives of Disease in Childhood 2003;88:482-7. 


\section{Doyle 2004}

Doyle LW, Faber B, Callanan C, Ford GW, Davis NM. Extremely low birth weight and body size in early adulthood. Archives of Disease in Childhood 2004;89:347-50. [PUBMED: 15033844]

\section{Dusick 2003}

Dusick AM, Poindexter BB, Ehrenkranz RA, Lemons JA. Growth failure in the preterm infant: can we catch up?. Seminars in Perinatology 2003;27(4):302-10. [PUBMED: 14510321]

\section{Embleton 2001}

Embleton NE, Pang N, Cooke RJ. Postnatal malnutrition and growth retardation: an inevitable consequence of current recommendations in preterm infants?. Pediatrics 2001;107:270-3.

\section{Embleton 2013}

Embleton ND. Early nutrition and later outcomes in preterm infants. World Review of Nutrition and Dietetics 2013;106:26-32. [PUBMED: 23428677]

\section{Euser 2005}

Euser AM, Finken MJ, Keijzer-Veen MG, Hille ET, Wit JM, Dekker FW. Associations between prenatal and infancy weight gain and BMI, fat mass, and fat distribution in young adulthood: a prospective cohort study in males and females born very preterm. American Journal of Clinical Nutrition 2005;81:480-7. [PUBMED: 15699238]

\section{Euser 2008}

Euser AM, de Wit CC, Finken MJ, Rijken M, Wit JM. Growth of preterm born children. Hormone Research 2008;70(6):319-28. [PUBMED: 18953169]

\section{Farooqi 2006}

Farooqi A, Hagglof B, Sedin G, Gothefors L, Serenius F. Growth in 10- to 12-year-old children born at 23 to 25 weeks' gestation in the 1990s: a Swedish national prospective follow-up study. Pediatrics 2006;118:e1452-65. [PUBMED: 17079546]

\section{Fewtrell 2003}

Fewtrell MS. Growth and nutrition after discharge. Seminars in Neonatology 2003;8(2):169-76. [PUBMED: 15001153]

\section{Fewtrell 2011}

Fewtrell M. Early nutritional predictors of long-term bone health in preterm infants. Current Opinion in Clinical Nutrition and Metabolic Care 2011;14(3):297-301. [PUBMED: 21378555]

\section{Ford 2000}

Ford GW, Doyle LW, Davis NM, Callanan C. Very low birth weight and growth into adolescence. Archives of Pediatrics and Adolescent Medicine 2000;154:778-84.

\section{GRADEpro 2008 [Computer program]}

Brozek J, Oxman A, Schünemann H. GRADEpro [Version 3.2 for Windows]. The GRADE Working Group, 2008.

\section{Greer 2007}

Greer FR. Post-discharge nutrition: what does the evidence support?. Seminars in Perinatology 2007;31:89-95. [PUBMED: 17462493]

\section{Griffin 2007}

Griffin IJ, Cooke RJ. Nutrition of preterm infants after hospital discharge. Journal of Pediatric Gastroenterology and Nutrition 2007;45 Suppl 3:S195-203. [PUBMED: 18185092]

\section{Guyatt 2011a}

Guyatt G, Oxman AD, Akl EA, Kunz R, Vist G, Brozek J, et al. GRADE guidelines: 1. Introduction - GRADE evidence profiles and summary of findings tables. Journal of Clinical Epidemiology 2011;64(4):383-94. [PUBMED: 21195583]

\section{Guyatt 2011b}

Guyatt GH, Oxman AD, Vist G, Kunz R, Brozek J, Alonso-Coello P, et al. GRADE guidelines: 4. Rating the quality of evidence study limitations (risk of bias). Journal of Clinical Epidemiology 2011;64(4):407-15. [PUBMED: 21247734]

\section{Guyatt 2011c}

Guyatt GH, Oxman AD, Kunz R, Brozek J, Alonso-Coello P, Rind $D$, et al. GRADE guidelines 6 . Rating the quality of evidence - imprecision. Journal of Clinical Epidemiology 2011;64(12):1283-93. [PUBMED: 21839614]

\section{Guyatt 2011d}

Guyatt GH, Oxman AD, Kunz R, Woodcock J, Brozek J, Helfand M, et al. GRADE guidelines: 7. Rating the quality of evidence - inconsistency. Journal of Clinical Epidemiology 2011;64(12):1294-302. [PUBMED: 21803546]

\section{Guyatt 2011e}

Guyatt GH, Oxman AD, Kunz R, Woodcock J, Brozek J, Helfand M, et al. GRADE guidelines: 8. Rating the quality of evidence - indirectness. Journal of Clinical Epidemiology 2011;64(12):1303-10. [PUBMED: 21802903]

\section{Hack 1991}

Hack M, Breslau N, Weissman B, Aram D, Klein N, Borawski E. Effect of very low birthweight and subnormal head size on cognitive abilities at school age. New England Journal of Medicine 1991;325:231-7.

\section{Hack 2003}

Hack M, Schluchter M, Cartar L, Rahman M, Cuttler L, Borawski E. Growth of very low birth weight infants to age 20 years. Pediatrics 2003;112:e30-8.

\section{Hancock 1984}

Hancock PJ, Bancalari E. Gastric motility in premature infants fed two different formulas. Journal of Pediatric Gastroenterology and Nutrition 1984;3:696-9.

\section{Higgins 2011}

Higgins JPT, Green S (editors). Cochrane Handbook for Systematic Reviews of Interventions Version 5.1.0 [updated March 2011]. The Cochrane Collaboration, 2011. www.cochranehandbook.org. 


\section{Hopewell 2009}

Hopewell S, Loudon K, Clarke MJ, Oxman AD, Dickersin K. Publication bias in clinical trials due to statistical significance or direction of trial results. Cochrane Database of Systematic Reviews 2009, Issue 1. [DOI: 10.1002/14651858.MR000006.pub3]

\section{Kleinman 2004}

Kleinman RE. Nutritional needs of the preterm infant. Pediatric Nutrition Handbook. 5th Edition. Chicago, Illinois, USA: American Academy of Pediatrics, 2004.

\section{Klingenberg 2011}

Klingenberg C, Embleton ND, Jacobs SE, O'Connell LA, Kuschel CA. Enteral feeding practices in very preterm infants: an international survey. Archives of Disease in Childhood. Fetal and Neonatal Edition 2011;97:F56-61. [PUBMED: 21856644]

\section{Lapillonne 2013}

Lapillonne A, Griffin IJ. Feeding preterm infants today for later metabolic and cardiovascular outcomes. Journal of Pediatrics 2013;162(3 Suppl):S7-16. [PUBMED: 23445851]

\section{Leppanen 2014}

Leppanen M, Lapinleimu H, Lind A, Matomaki J, Lehtonen L, Haataja L, et al. Antenatal and postnatal growth and 5year cognitive outcome in very preterm infants. Pediatrics 2014;133(1):63-70. [PUBMED: 24344103]

\section{Lucas 1984}

Lucas A, Gore SM, Cole TJ, Bamford MF, Dossetor JF, Barr I, et al. Multicentre trial on feeding low birthweight infants: effects of diet on early growth. Archives of Disease in Childhood 1984;59:722-30.

\section{Lucas 1992a}

Lucas A, King F, Bishop NB. Postdischarge formula consumption in infants born preterm. Archives of Disease in Childhood 1992;67:691-2.

\section{McCormick 2013}

Young L, Embleton ND, McCormick FM, McGuire W. Multinutrient fortification of human breast milk for preterm infants following hospital discharge. Cochrane Database of Systematic Reviews 2013, Issue 2. [DOI: 10.1002/14651858.CD004866.pub3]

\section{Saigal 2006}

Saigal S, Stoskopf B, Streiner D, Paneth N, Pinelli J, Boyle M. Growth trajectories of extremely low birth weight infants from birth to young adulthood: a longitudinal, population-based study. Pediatric Research 2006;60:751-8. [PUBMED: 17065570]

\section{Schünemann 2013}

Schünemann H, Brożek J, Guyatt G, Oxman A, editors. GWG. GRADE Handbook for Grading Quality of Evidence and Strength of Recommendations. www.guidelinedevelopment.org/ handbook. Updated October 2013.

\section{Siegel 1984}

Siegel M, Lebenthal E, Krantz B. Effect of caloric density on gastric emptying in premature infants. Journal of Pediatrics 1984;104:118-22.

\section{Trebar 2007}

Trebar B, Traunecker R, Selbmann HK, Ranke MB. Growth during the first two years predicts pre-school height in children born with very low birth weight (VLBW): results of a study of 1,320 children in Germany. Pediatric Research 2007;62:209-14. [PUBMED: 17597641]

\section{References to other published versions of this review \\ McGuire 2007}

Henderson G, Fahey T, McGuire W. Nutrient-enriched formula versus standard formula for preterm infants following hospital discharge. Cochrane Database of Systematic Reviews 2007, Issue 4. [DOI: 10.1002/14651858.CD004696.pub3]

\section{Young 2012}

Young L, Morgan J, McCormick FM, McGuire W. Nutrientenriched formula versus standard term formula for preterm infants following hospital discharge. Cochrane Database of Systematic Reviews 2012, Issue 3. [DOI: 10.1002/14651858.CD004696.pub4]

* Indicates the major publication for the study

\section{CHARACTERISTICS OF STUDIES}

Characteristics of included studies [ordered by study ID]

Agosti 2003

\begin{tabular}{|c|c|}
\hline Methods & Randomised controlled trial \\
\hline Participants & 121 formula milk-fed VLBW $(<1500 \mathrm{~g})$ infants \\
\hline Interventions & $\begin{array}{l}\text { Preterm formula (energy content } 80 \mathrm{kcal} / 100 \mathrm{~mL} \text {, protein content } 2.4 \mathrm{~g} / 100 \mathrm{~mL} \text {, calcium and phospho- } \\
\text { rus content } 100 \mathrm{mg} / 100 \mathrm{~mL} \text { and } 50 \mathrm{mg} / 100 \mathrm{~mL} \text {, respectively) }(\mathrm{N}=69) \text { or standard term formula (energy } \\
\text { content } 70 \mathrm{kcal} / 100 \mathrm{~mL} \text {, protein content } 1.7 \mathrm{~g} / 100 \mathrm{~mL})(\mathrm{N}=52) \text {. The intention was for the allocated for- } \\
\text { mula to be the only milk source from } 40 \text { weeks until } 55 \text { weeks postmenstrual age (PMA) }\end{array}$ \\
\hline
\end{tabular}


Agosti 2003 (Continued)

Outcomes Growth parameters and Griffiths Developmental Scale at 40 weeks, 55 weeks PMA and 6 and 12 months' corrected age

Notes

Setting: multi-centre trial in Italy (2001)

Research supported by Milupa (formula milk manufacturing company)

Numerical growth data obtained from primary investigators (June 2011)

\section{Risk of bias}

\begin{tabular}{|c|c|c|}
\hline Bias & Authors' judgement & Support for judgement \\
\hline $\begin{array}{l}\text { Random sequence genera- } \\
\text { tion (selection bias) }\end{array}$ & Unclear risk & Report states simply that infants were "randomised" to study groups. \\
\hline $\begin{array}{l}\text { Allocation concealment } \\
\text { (selection bias) }\end{array}$ & Unclear risk & Randomisation method was not mentioned. \\
\hline $\begin{array}{l}\text { Incomplete outcome data } \\
\text { (attrition bias) } \\
\text { All outcomes }\end{array}$ & High risk & Loss to follow-up was $34 \%$ at 6 months and $66 \%$ at 12 months. \\
\hline $\begin{array}{l}\text { Blinding of participants } \\
\text { and personnel (perfor- } \\
\text { mance bias) } \\
\text { All outcomes }\end{array}$ & High risk & Families and caregivers were aware of which formula milk infants received. \\
\hline $\begin{array}{l}\text { Blinding of outcome as- } \\
\text { sessment (detection bias) } \\
\text { All outcomes }\end{array}$ & Low risk & $\begin{array}{l}\text { Outcome assessors were unlikely to have been aware of which formula milk in- } \\
\text { fants received. }\end{array}$ \\
\hline
\end{tabular}

\section{Atkinson 1999}

\begin{tabular}{|c|c|c|}
\hline Methods & \multicolumn{2}{|c|}{ Randomised controlled trial } \\
\hline Participants & \multicolumn{2}{|c|}{70 formula milk-fed preterm infants of birth weight < $1800 \mathrm{~g}$ and 'appropriate for gestational age' } \\
\hline Interventions & \multicolumn{2}{|c|}{$\begin{array}{l}\text { Postdischarge formula (energy content } 74 \mathrm{kcal} / 100 \mathrm{~mL} \text {, protein content } 1.8 \mathrm{~g} / 100 \mathrm{~mL} \text { ) }(\mathrm{N}=34 \text { ) vs stan- } \\
\text { dard term formula }(\mathrm{N}=36) \text { for } 12 \text { months post discharge }\end{array}$} \\
\hline Outcomes & \multicolumn{2}{|c|}{ Growth parameters at 6, 9 and 12 months' corrected age } \\
\hline Notes & \multicolumn{2}{|c|}{ Published in abstract form only. Additional information and data courtesy of Dr Stephanie Atkinson } \\
\hline \multicolumn{3}{|l|}{ Risk of bias } \\
\hline Bias & Authors' judgement & Support for judgement \\
\hline $\begin{array}{l}\text { Random sequence genera- } \\
\text { tion (selection bias) }\end{array}$ & Low risk & Random sequence was independently generated. \\
\hline $\begin{array}{l}\text { Allocation concealment } \\
\text { (selection bias) }\end{array}$ & Low risk & Allocation was drawn from sequential sealed opaque envelopes. \\
\hline
\end{tabular}


Atkinson 1999 (Continued)

Incomplete outcome data High risk Growth outcome data to 12 months were available for 24 (71\%) intervention (attrition bias) group and 29 (81\%) control group infants.

All outcomes

Blinding of participants Low risk Families and caregivers were unaware of which formula milk infants received.
and personnel (perfor-
mance bias)
All outcomes

Blinding of outcome as- Low risk

Outcome assessors were not aware of which formula milk infants received. sessment (detection bias)

All outcomes

\section{Atkinson 2004}

\begin{tabular}{ll}
\hline Methods & Randomised controlled trial \\
\hline Participants & 53 formula milk-fed preterm 'small for gestational age' infants \\
\hline Interventions & $\begin{array}{l}\text { Postdischarge formula (energy content } 74 \mathrm{kcal} / 100 \mathrm{~mL} \text {, protein content } 1.8 \mathrm{~g} / 100 \mathrm{~mL})(\mathrm{N}=24) \mathrm{vs} \mathrm{stan} \text { - } \\
\text { dard term formula (Ross Similac With Fe) }(\mathrm{N}=29) \text { for } 12 \text { months post discharge }\end{array}$ \\
\hline Outcomes & Growth parameters at 6,9 and 12 months' corrected age \\
\hline Notes & Published in abstract form only. Additional information and data courtesy of Dr Stephanie Atkinson
\end{tabular}

\section{Risk of bias}

\begin{tabular}{|c|c|c|}
\hline Bias & Authors' judgement & Support for judgement \\
\hline $\begin{array}{l}\text { Random sequence genera- } \\
\text { tion (selection bias) }\end{array}$ & Low risk & Random sequence was independently generated. \\
\hline $\begin{array}{l}\text { Allocation concealment } \\
\text { (selection bias) }\end{array}$ & Low risk & Allocation was drawn from sequential sealed opaque envelopes. \\
\hline $\begin{array}{l}\text { Incomplete outcome data } \\
\text { (attrition bias) } \\
\text { All outcomes }\end{array}$ & Low risk & Follow-up growth parameter outcome assessments were completed. \\
\hline $\begin{array}{l}\text { Blinding of participants } \\
\text { and personnel (perfor- } \\
\text { mance bias) } \\
\text { All outcomes }\end{array}$ & Low risk & Families and caregivers were unaware of which formula milk infants received. \\
\hline $\begin{array}{l}\text { Blinding of outcome as- } \\
\text { sessment (detection bias) } \\
\text { All outcomes }\end{array}$ & Low risk & Outcomes assessors were not aware of which formula milk infants received. \\
\hline
\end{tabular}

Carver 2001

Methods Randomised controlled trial


Carver 2001 (Continued)

Participants 125 preterm infants (birth weight $<1800 \mathrm{~g}$ or gestation $<37$ weeks). Infants with severe bronchopulmonary dysplasia or cardiac, respiratory, gastrointestinal or other systemic diseases at time of discharge were not eligible to participate.

Interventions Postdischarge formula (energy content $74 \mathrm{kcal} / 100 \mathrm{~mL}$, protein content $1.9 \mathrm{~g} / 100 \mathrm{~mL}$, calcium and phosphorus content $78 \mathrm{mg} / 100 \mathrm{~mL}$ and $46 \mathrm{mg} / 100 \mathrm{~mL}$, respectively) $(\mathrm{N}=67)$ or standard term formula (energy content $68 \mathrm{kcal} / 100 \mathrm{~mL}$, protein content $1.5 \mathrm{~g} / 100 \mathrm{~mL})(\mathrm{N}=56)$. The intention was for the allocated formula to be the main milk source from hospital discharge until 12 months' corrected age.

\begin{tabular}{ll}
\hline Outcomes & Growth parameters assessed at intervals until the end of the 12-month study period \\
\hline Notes & Setting: multi-centre - 6 perinatal centres in North America
\end{tabular}

\section{Risk of bias}

\begin{tabular}{|c|c|c|}
\hline Bias & Authors' judgement & Support for judgement \\
\hline $\begin{array}{l}\text { Random sequence genera- } \\
\text { tion (selection bias) }\end{array}$ & Low risk & Method used to generate random sequence was not described. \\
\hline $\begin{array}{l}\text { Allocation concealment } \\
\text { (selection bias) }\end{array}$ & Unclear risk & No information on randomisation method was provided. \\
\hline $\begin{array}{l}\text { Incomplete outcome data } \\
\text { (attrition bias) } \\
\text { All outcomes }\end{array}$ & High risk & $\begin{array}{l}31 \text { of } 67 \text { in postdischarge formula group and } 26 \text { of } 56 \text { in standard term formula } \\
\text { group left the study early (plus } 2 \text { other infants, who were randomised but did } \\
\text { not take part in the study). Total loss of follow-up for growth parameters as- } \\
\text { sessed at } 12 \text { months was } 60 \% \text { in the intervention group and } 52 \% \text { in the control } \\
\text { group. } \\
\text { Infants exited the study early (without growth parameters measured) for a va- } \\
\text { riety of reasons, including study non-compliance (not defined or described), } \\
\text { gastrointestinal upset and "illness unrelated to the study feedings" (not de- } \\
\text { fined or described). }\end{array}$ \\
\hline
\end{tabular}

Blinding of participants Low risk Families and caregivers were unaware of which formula milk infants received.
and personnel (perfor-
mance bias)
All outcomes

Blinding of outcome as- Low risk Outcome assessors were not aware of which formula milk infants received.
sessment (detection bias)

All outcomes

\begin{tabular}{ll} 
Cooke 2001 & Randomised controlled trial \\
\hline Methods & $\begin{array}{l}103 \text { preterm infants (birth weight }<1750 \text { g or gestation }<35 \text { weeks). Only infants who were 'growing } \\
\text { normally' (rate of weight gain }>25 \mathrm{~g} / \mathrm{kg} / \mathrm{d} \text { ) at the time of discharge were eligible to participate. }\end{array}$ \\
\hline Interventions & $\begin{array}{l}\text { Preterm formula (energy content } 80 \mathrm{kcal} / 100 \mathrm{~mL}, \text { protein content } 2.2 \mathrm{~g} / 100 \mathrm{~mL}, \text { calcium and phospho- } \\
\text { rus content } 108 \mathrm{mg} / 100 \mathrm{~mL} \text { and } 54 \mathrm{mg} / 100 \mathrm{~mL}, \text { respectively) }(\mathrm{N}=49) \text { or standard term formula (energy } \\
\text { content } 66 \mathrm{kcal} / 100 \mathrm{~mL}, \text { protein content } 1.4 \mathrm{~g} / 100 \mathrm{~mL})(\mathrm{N}=54) \text { from hospital discharge until } 6 \mathrm{months} \\
\text { corrected age }\end{array}$
\end{tabular}


Cooke 2001 (Continued)

Outcomes Anthropometric and developmental parameters (including Bayley Scales of Infant Development II), measures of bone mineralisation

Notes

Setting: Royal Victoria Hospital, Newcastle upon Tyne, UK

Research supported by Nutricia (formula milk manufacturer)

Article reported growth data for boys and girls separately. We combined data for inclusion in this re-

view.

\section{Risk of bias}

\begin{tabular}{|c|c|c|}
\hline Bias & Authors' judgement & Support for judgement \\
\hline $\begin{array}{l}\text { Random sequence genera- } \\
\text { tion (selection bias) }\end{array}$ & Low risk & Random sequence was centrally generated. \\
\hline $\begin{array}{l}\text { Allocation concealment } \\
\text { (selection bias) }\end{array}$ & Low risk & Sealed opaque envelopes were used. \\
\hline $\begin{array}{l}\text { Incomplete outcome data } \\
\text { (attrition bias) } \\
\text { All outcomes }\end{array}$ & Low risk & Follow-up was near complete (> 80\%). \\
\hline $\begin{array}{l}\text { Blinding of participants } \\
\text { and personnel (perfor- } \\
\text { mance bias) } \\
\text { All outcomes }\end{array}$ & Low risk & Families and caregivers were unaware of which formula milk infants received. \\
\hline $\begin{array}{l}\text { Blinding of outcome as- } \\
\text { sessment (detection bias) } \\
\text { All outcomes }\end{array}$ & Low risk & Outcome assessors were not aware of which formula milk infants received. \\
\hline
\end{tabular}

De Curtis 2002

\begin{tabular}{ll}
\hline Methods & Randomised controlled trial \\
\hline Participants & 33 formula milk-fed preterm infants (birth weight < 1750 g or gestation <35 weeks) \\
\hline Interventions & $\begin{array}{l}\text { Postdischarge formula (energy content } 74 \mathrm{kcal} / 100 \mathrm{~mL}, \text { protein content } 1.8 \mathrm{~g} / 100 \mathrm{~mL}, \mathrm{calcium} \text { and } \\
\text { phosphorus content } 80 \mathrm{mg} / 100 \mathrm{~mL} \text { and } 40 \mathrm{mg} / 100 \mathrm{~mL}, \text { respectively) }(\mathrm{N}=16) \text { or standard term formula } \\
\text { (energy content } 66 \mathrm{kcal} / 100 \mathrm{~mL}, \text { protein content } 1.4 \mathrm{~g} / 100 \mathrm{~mL})(\mathrm{N}=17) \text { from hospital discharge until } 2 \\
\text { months' corrected age }\end{array}$ \\
\hline Outcomes & $\begin{array}{l}\text { Growth parameters and bone mineralisation measured by dual-energy X-ray absorptiometry at the end } \\
\text { of the 2-month study period }\end{array}$ \\
\hline Notes & Setting: Department of Pediatrics, University of Liege, Belgium \\
\hline Risk of bias & Authors' judgement Support for judgement \\
\hline Bias & Unclear risk Method used to generate random sequence was not described. \\
\hline $\begin{array}{l}\text { Random sequence genera- } \\
\text { tion (selection bias) }\end{array}$
\end{tabular}


De Curtis 2002 (Continued)

Allocation concealment Unclear risk No information on randomisation method was provided. (selection bias)

Incomplete outcome data Low risk

Follow-up was near complete (>90\%).

(attrition bias)

All outcomes

Blinding of participants Low risk Families and caregivers were unaware of which formula milk infants received.
and personnel (perfor-
mance bias)
All outcomes

\begin{tabular}{ll}
\hline Blinding of outcome as- & Low risk \\
sessment (detection bias) & \\
All outcomes &
\end{tabular}

Jeon 2011

\begin{tabular}{ll}
\hline Methods & Randomised controlled trial \\
\hline Participants & 59 preterm very low birth weight infants \\
\hline Interventions & $\begin{array}{l}\text { Preterm formula (energy content } 80 \mathrm{kcal} / 100 \mathrm{~mL}, \text { protein content } 2.3 \mathrm{~g} / 100 \mathrm{~mL}, \text { calcium and phospho- } \\
\text { rus content } 128 \mathrm{mg} / 100 \mathrm{~mL} \text { and } 64 \mathrm{mg} / 100 \mathrm{~mL}, \text { respectively) }(\mathrm{N}=34) \text { or standard term formula (energy } \\
\text { content } 67 \mathrm{kcal} / 100 \mathrm{~mL}, \mathrm{protein} \text { content } 1.6 \mathrm{~g} / 100 \mathrm{~mL})(\mathrm{N}=34) \text { from hospital discharge until } 3 \mathrm{months} \\
\text { post term, then both groups continued with standard term formula until at least } 6 \text { months post term }\end{array}$ \\
\hline Outcomes & $\begin{array}{l}\text { Growth parameters at 3-monthly intervals until } 18 \text { months post term, Bayley Scales of Infant Develop- } \\
\text { ment II at } 18 \text { months' corrected age }\end{array}$ \\
\hline Sotes & $\begin{array}{l}\text { Setting: multi-centre trial in } 4 \text { hospitals in South Korea } \\
\text { Research supported by Maeli Dairy Industry Co. Ltd. (formula milk manufacturer) }\end{array}$ \\
$\begin{array}{l}\text { Initially, } 3 \text { groups were randomly allocated to receive (1) standard term formula, (2) preterm formula } \\
\text { for } 3 \text { months or (3) preterm formula for } 6 \text { months. However, results showed substantial and significant } \\
\text { between-group differences in baseline demographic characteristics, especially between group (3) and } \\
\text { the other groups. Group (3) infants had statistically significantly lower birth weight and were more like- } \\
\text { ly to be small for gestational age. We therefore chose to discard data from this arm and to restrict com- } \\
\text { parison of outcomes to group (1) vs group (3). }\end{array}$ \\
\hline
\end{tabular}

\section{Risk of bias}

\begin{tabular}{lll}
\hline Bias & Authors' judgement & Support for judgement \\
\hline $\begin{array}{l}\text { Random sequence genera- } \\
\text { tion (selection bias) }\end{array}$ & Unclear risk & Method used to generate random sequence was not described. \\
\hline $\begin{array}{l}\text { Allocation concealment } \\
\text { (selection bias) }\end{array}$ & Unclear risk & No information on randomisation method was provided. \\
\hline $\begin{array}{l}\text { Incomplete outcome data } \\
\text { (attrition bias) } \\
\text { All outcomes }\end{array}$ & Low risk & $\begin{array}{l}\text { Growth outcome data to } 18 \text { months were available for } 30(88 \%) \text { intervention } \\
\text { group and } 29(85 \%) \text { control group infants. }\end{array}$ \\
\hline
\end{tabular}


Jeon 2011 (Continued)

Blinding of participants High risk Families and caregivers were likely to have been aware of which formula milk and personnel (perforinfants received.

mance bias)

All outcomes

Blinding of outcome as- Unclear risk sessment (detection bias)

All outcomes
Outcome assessors may have been aware of which formula milk infants received.

Koo 2006

\begin{tabular}{ll}
\hline Methods & Randomised controlled trial \\
\hline Participants & $\begin{array}{l}89 \text { preterm infants ready for hospital discharge (gestational age at birth }<35 \text { weeks). Infants with ma- } \\
\text { jor congenital malformation, previous gastrointestinal surgery or abnormal suck and swallow actions } \\
\text { were not eligible to participate. }\end{array}$ \\
\hline Interventions & $\begin{array}{l}\text { Nutrient-enriched formula (energy content } 74 \mathrm{kcal} / 100 \mathrm{~mL}, \text { protein content } 1.9 \mathrm{~g} / 100 \mathrm{~mL}, \mathrm{calcium} \text { and } \\
\text { phosphorus content } 78 \mathrm{mg} / 100 \mathrm{~mL} \text { and } 46 \mathrm{mg} / 100 \mathrm{~mL}, \text { respectively) }(\mathrm{N}=44) \text { or standard term formula } \\
\text { (energy content } 67 \mathrm{kcal} / 100 \mathrm{~mL}, \mathrm{protein} \text { content } 1.5 \mathrm{~g} / 100 \mathrm{~mL})(\mathrm{N}=45) . \text { The intention was for the allo- } \\
\text { cated formula to be fed ad libitum until } 12 \mathrm{months} \text { after discharge. }\end{array}$ \\
\hline Outcomes & Growth parameters and bone mineral content at intervals until the end of the 12-month study period \\
\hline Notes & Setting: Department of Pediatrics, Wayne State University, and Hutzel Hospital, Detroit, Michigan, USA \\
Research supported by Ross Products Division, Abbott Laboratories (formula milk manufacturer)
\end{tabular}

\section{Risk of bias}

\begin{tabular}{|c|c|c|}
\hline Bias & Authors' judgement & Support for judgement \\
\hline $\begin{array}{l}\text { Random sequence genera- } \\
\text { tion (selection bias) }\end{array}$ & Unclear risk & Method used to generate random sequence was not described. \\
\hline $\begin{array}{l}\text { Allocation concealment } \\
\text { (selection bias) }\end{array}$ & Low risk & Allocation was drawn from sequential sealed opaque envelopes. \\
\hline $\begin{array}{l}\text { Incomplete outcome data } \\
\text { (attrition bias) } \\
\text { All outcomes }\end{array}$ & High risk & $\begin{array}{l}\text { Growth outcome data to } 12 \text { months were available for } 31(70 \%) \text { intervention } \\
\text { group and } 36(80 \%) \text { control group infants. }\end{array}$ \\
\hline $\begin{array}{l}\text { Blinding of participants } \\
\text { and personnel (perfor- } \\
\text { mance bias) } \\
\text { All outcomes }\end{array}$ & Low risk & Families and caregivers were unaware of which formula milk infants received. \\
\hline $\begin{array}{l}\text { Blinding of outcome as- } \\
\text { sessment (detection bias) } \\
\text { All outcomes }\end{array}$ & Low risk & Outcome assessors were not aware of which formula milk infants received. \\
\hline
\end{tabular}


Litmanovitz 2004

\begin{tabular}{|c|c|c|}
\hline Methods & \multicolumn{2}{|c|}{ Randomised controlled trial } \\
\hline Participants & \multicolumn{2}{|c|}{20 healthy very low birth weight infants at hospital discharge } \\
\hline Interventions & \multicolumn{2}{|c|}{$\begin{array}{l}\text { Nutrient-enriched formula (energy content } 74 \mathrm{kcal} / 100 \mathrm{~mL} \text {, protein content } 1.9 \mathrm{~g} / 100 \mathrm{~mL})(\mathrm{N}=10 \text { ) or } \\
\text { standard term formula (energy content } 67 \mathrm{kcal} / 100 \mathrm{~mL} \text {, protein content } 1.5 \mathrm{~g} / 100 \mathrm{~mL} \text { ) }(\mathrm{N}=10) \text { after } \\
\text { hospital discharge. Formula was intended to provide sole milk intake up to } 6 \text { months' corrected age. }\end{array}$} \\
\hline Outcomes & \multicolumn{2}{|c|}{$\begin{array}{l}\text { Weight, length, head circumference and measures of bone mineralisation at term and at } 6 \text { months' cor- } \\
\text { rected age }\end{array}$} \\
\hline Notes & \multicolumn{2}{|c|}{ Setting: Meir General Hospital, Kfar-saba, Israel } \\
\hline \multicolumn{3}{|l|}{ Risk of bias } \\
\hline Bias & Authors' judgement & Support for judgement \\
\hline $\begin{array}{l}\text { Random sequence genera- } \\
\text { tion (selection bias) }\end{array}$ & Unclear risk & Method used to generate random sequence was not described. \\
\hline $\begin{array}{l}\text { Allocation concealment } \\
\text { (selection bias) }\end{array}$ & Unclear risk & No information on randomisation method was provided. \\
\hline $\begin{array}{l}\text { Incomplete outcome data } \\
\text { (attrition bias) } \\
\text { All outcomes }\end{array}$ & Low risk & Follow-up was near complete (> 80\%). \\
\hline $\begin{array}{l}\text { Blinding of participants } \\
\text { and personnel (perfor- } \\
\text { mance bias) } \\
\text { All outcomes }\end{array}$ & Unclear risk & $\begin{array}{l}\text { No information was provided on whether families and caregivers were aware } \\
\text { of which formula milk infants received. }\end{array}$ \\
\hline $\begin{array}{l}\text { Blinding of outcome as- } \\
\text { sessment (detection bias) } \\
\text { All outcomes }\end{array}$ & Unclear risk & $\begin{array}{l}\text { No information was provided on whether outcome assessors were aware of } \\
\text { which formula milk infants received. }\end{array}$ \\
\hline
\end{tabular}

Lucas 1992

\begin{tabular}{ll}
\hline Methods & Randomised controlled trial \\
\hline Participants & $\begin{array}{l}32 \text { exclusively formula milk-fed preterm infants, birth weight }<1850 \mathrm{~g} \text {, weight }<3000 \mathrm{~g} \text { at hospital dis- } \\
\text { charge }\end{array}$ \\
\hline Interventions & $\begin{array}{l}\text { Nutrient-enriched formula (energy content } 72 \mathrm{kcal} / 100 \mathrm{~mL} \text {, protein content } 1.8 \mathrm{~g} / 100 \mathrm{~mL}, \mathrm{calcium} \text { and } \\
\text { phosphorus content } 70 \mathrm{mg} / 100 \mathrm{~mL} \text { and } 35 \mathrm{mg} / 100 \mathrm{~mL}, \text { respectively) }(\mathrm{N}=16) \text { or standard term formula } \\
\text { (energy content } 68 \mathrm{kcal} / 100 \mathrm{~mL}, \text { protein content } 1.4 \mathrm{~g} / 100 \mathrm{~mL})(\mathrm{N}=16) \text { after hospital discharge. Formu- } \\
\text { la was intended to provide sole milk intake up to } 9 \text { months' corrected age. }\end{array}$
\end{tabular}

Outcomes

Measures of growth (weight, crown-heel length and head circumference), feed tolerance, bone mineralisation during trial period

Notes

Setting: Department of Paediatrics, Rosie Maternity Hospital, Cambridge

Research supported by Farley Health Products (formula milk company)

One infant who was randomised to the standard term formula group was transferred to another hospi-

tal before planned hospital discharge and could not be included in follow-up assessments. 
Data were presented graphically. We extracted numerical data (mean and SD) from the graphs to calculate mean differences.

\begin{tabular}{|c|c|c|}
\hline \multicolumn{3}{|l|}{ Risk of bias } \\
\hline Bias & Authors' judgement & Support for judgement \\
\hline $\begin{array}{l}\text { Random sequence genera- } \\
\text { tion (selection bias) }\end{array}$ & Unclear risk & Method used to generate random sequence was not described. \\
\hline $\begin{array}{l}\text { Allocation concealment } \\
\text { (selection bias) }\end{array}$ & Unclear risk & No information on randomisation method was provided. \\
\hline $\begin{array}{l}\text { Incomplete outcome data } \\
\text { (attrition bias) } \\
\text { All outcomes }\end{array}$ & Low risk & $\begin{array}{l}\text { Follow-up was near complete ( } 1 \text { infant from the standard term formula group } \\
\text { was withdrawn). }\end{array}$ \\
\hline $\begin{array}{l}\text { Blinding of participants } \\
\text { and personnel (perfor- } \\
\text { mance bias) } \\
\text { All outcomes }\end{array}$ & Low risk & $\begin{array}{l}\text { It is likely that families and caregivers were unaware of which formula milk in- } \\
\text { fants received. }\end{array}$ \\
\hline $\begin{array}{l}\text { Blinding of outcome as- } \\
\text { sessment (detection bias) } \\
\text { All outcomes }\end{array}$ & Low risk & $\begin{array}{l}\text { It is likely that outcome assessors were unaware of which formula milk infants } \\
\text { received. }\end{array}$ \\
\hline
\end{tabular}

Lucas 2001

\begin{tabular}{ll}
\hline Methods & Randomised controlled trial \\
\hline Participants & 229 formula milk-fed preterm infants, birth weight $<1750 \mathrm{~g}$, weight $<3000 \mathrm{~g}$ at hospital discharge \\
\hline Interventions & $\begin{array}{l}\text { Nutrient-enriched formula (energy content } 72 \mathrm{kcal} / 100 \mathrm{~mL}, \text { protein content } 1.85 \mathrm{~g} / 100 \mathrm{~mL}, \mathrm{calcium} \text { and } \\
\text { phosphorus content } 70 \mathrm{mg} / 100 \mathrm{~mL} \text { and } 35 \mathrm{mg} / 100 \mathrm{~mL}, \text { respectively) }(\mathrm{N}=113) \text { or standard term formula } \\
\text { (energy content } 68 \mathrm{kcal} / 100 \mathrm{~mL}, \text { protein content } 1.5 \mathrm{~g} / 100 \mathrm{~mL})(\mathrm{N}=116) \text { from hospital discharge until } 9 \\
\text { months post term }\end{array}$ \\
\hline
\end{tabular}

Outcomes Growth parameters up to 18 months post term, neurodevelopment (Bayley Scales) at 18 months' corrected age

\begin{tabular}{lll}
\hline Notes & $\begin{array}{l}\text { Setting: } 5 \text { neonatal centres in the UK (1993-1995) } \\
\text { Research supported by Farley Health Products (formula milk company) }\end{array}$ \\
\hline Risk of bias & Authors' judgement & Support for judgement \\
\hline Bias & Low risk & $\begin{array}{l}\text { A member of the clinical team not involved in the trial prepared randomisation } \\
\text { assignments. }\end{array}$ \\
\hline $\begin{array}{l}\text { Random sequence genera- } \\
\text { tion (selection bias) }\end{array}$ & Allocation was drawn from sequential sealed opaque envelopes. \\
\hline $\begin{array}{l}\text { Allocation concealment } \\
\text { (selection bias) }\end{array}$ & Low risk & $\begin{array}{l}\text { Growth and developmental outcomes were assessed in > 80\% of participating } \\
\text { infants. }\end{array}$ \\
\hline $\begin{array}{l}\text { Incomplete outcome data } \\
\text { (attrition bias) }\end{array}$ & Low risk &
\end{tabular}


Lucas 2001 (Continued)

All outcomes

Blinding of participants

mance bias)

All outcomes

Blinding of outcome as- Low risk

Outcome assessors were unaware of which formula milk infants received. sessment (detection bias)

All outcomes

\section{Peng 2004}

\begin{tabular}{|c|c|}
\hline Methods & Randomised controlled trial \\
\hline Participants & 34 preterm infants with gestational age of $\leq 35$ weeks and birth weight $\leq 1850 \mathrm{~g}$ \\
\hline Interventions & $\begin{array}{l}\text { Nutrient-enriched formula (energy content } 81 \mathrm{kcal} / 100 \mathrm{~mL} \text {, protein content } 2.40 \mathrm{~g} / 100 \mathrm{~mL} \text {, calcium and } \\
\text { phosphorus content } 95 \mathrm{mg} / 100 \mathrm{~mL} \text { and } 53 \mathrm{mg} / 100 \mathrm{~mL} \text {, respectively) }(\mathrm{N}=19) \text { or standard term formula } \\
\text { (energy content } 67.6 \mathrm{kcal} / 100 \mathrm{~mL} \text {, protein content } 1.4 \mathrm{~g} / 100 \mathrm{~mL})(\mathrm{N}=15) \text { from hospital-discharge until } \\
6 \text { months' corrected age }\end{array}$ \\
\hline Outcomes & $\begin{array}{l}\text { Measures of growth (weight, crown-heel length and head circumference), feed tolerance, bone mineral- } \\
\text { isation during trial period }\end{array}$ \\
\hline \multirow[t]{3}{*}{ Notes } & Setting: Mackay Memorial Hospital, Taipei, Taiwan \\
\hline & Research supported by Mead Johnson (formula milk company) \\
\hline & $\begin{array}{l}\text { No differences were found between the } 2 \text { groups in weight, length or head circumference at baseline } \\
\text { or on follow-up. Infants fed premature formula had higher blood urea nitrogen and phosphorus at } 3 \\
\text { months' corrected age. Those on the premature formula also had higher energy intake at } 1 \text { month cor- } \\
\text { rected age. }\end{array}$ \\
\hline
\end{tabular}

\section{Risk of bias}

\begin{tabular}{lll}
\hline Bias & Authors' judgement & Support for judgement \\
\hline $\begin{array}{l}\text { Random sequence genera- } \\
\text { tion (selection bias) }\end{array}$ & Unclear risk & Method used to generate random sequence was not described. \\
\hline $\begin{array}{l}\text { Allocation concealment } \\
\text { (selection bias) }\end{array}$ & Unclear risk & No information on randomisation method was provided. \\
\hline $\begin{array}{l}\text { Incomplete outcome data } \\
\text { (attrition bias) }\end{array}$ & High risk & $\begin{array}{l}\text { Growth outcome data to } 6 \text { months were available for 29 of the 40 infants ini- } \\
\text { tially enrolled (73\%). }\end{array}$ \\
\hline $\begin{array}{l}\text { Blinding of participants } \\
\text { and personnel (perfor- } \\
\text { mance bias) } \\
\begin{array}{l}\text { All outcomes } \\
\text { Blinding of outcome as- }\end{array}\end{array}$ & High risk & High risk \\
$\begin{array}{l}\text { sessment (detection bias) } \\
\text { All outcomes }\end{array}$ & $\begin{array}{l}\text { Families and caregivers were likely to have been aware of which formula milk } \\
\text { infants received, as parents were not blinded to infant assignment. }\end{array}$ \\
\hline
\end{tabular}


Picaud 2005

\begin{tabular}{ll}
\hline Methods & Randomised controlled trial \\
\hline Participants & 49 formula milk-fed preterm infants, birth weight $<1750 \mathrm{~g}$ or gestation at birth <33 weeks \\
\hline Interventions & $\begin{array}{l}\text { Preterm formula (energy content } 81 \mathrm{kcal} / 100 \mathrm{~mL}, \text { protein content } 2.3 \mathrm{~g} / 100 \mathrm{~mL}, \text { calcium and phospho- } \\
\text { rus content } 100 \mathrm{mg} / 100 \mathrm{~mL} \text { and } 53 \mathrm{mg} / 100 \mathrm{~mL}, \text { respectively) }(\mathrm{N}=23) \text { or standard term formula (energy } \\
\text { content } 67 \mathrm{kcal} / 100 \mathrm{~mL}, \text { protein content } 1.7 \mathrm{~g} / 100 \mathrm{~mL})(\mathrm{N}=26) \text { from hospital discharge until } 2 \mathrm{months} \\
\text { post term }\end{array}$
\end{tabular}

Outcomes Growth parameters and measures of bone mineralisation up to 4 months' corrected age

\begin{tabular}{ll}
\hline Notes & Setting: 2 tertiary care neonatal units in France (2001-2004) \\
& Research supported by Nestlé France (formula milk manufacturer) \\
From 2 months post discharge, both groups received standard term formula milk.
\end{tabular}

\section{Risk of bias}

\begin{tabular}{lll}
\hline Bias & Authors' judgement & Support for judgement \\
\hline $\begin{array}{l}\text { Random sequence genera- } \\
\text { tion (selection bias) }\end{array}$ & Low risk & Clinical trials unit was generated. \\
\hline $\begin{array}{l}\text { Allocation concealment } \\
\text { (selection bias) }\end{array}$ & Low risk & Pharmacy was coded. \\
\hline $\begin{array}{l}\text { Incomplete outcome data } \\
\text { (attrition bias) } \\
\text { All outcomes }\end{array}$ & High risk & Loss to follow-up by 12 months in the control group was substantial (35\%) and \\
was greater than in the intervention group (9\%).
\end{tabular}

Blinding of participants Low risk Families and caregivers were unaware of which formula milk infants received.
and personnel (perfor-
mance bias)
All outcomes

Blinding of outcome as- Low risk Outcome assessors were unaware of which formula milk infants received. sessment (detection bias)

All outcomes

\section{Roggero 2011}

\begin{tabular}{ll}
\hline Methods & Randomised controlled trial \\
\hline Participants & 123 formula fed preterm infants who were 'appropriate (birth weight) for gestational age' \\
\hline Interventions & $\begin{array}{l}\text { Postdischarge formula (energy content } 75 \mathrm{kcal} / 100 \mathrm{~mL}, \text { protein content } 2.0 \mathrm{~g} / 100 \mathrm{~mL}, \text { calcium and } \\
\text { phosphorus content } 100 \mathrm{mg} / 100 \mathrm{~mL} \text { and } 56 \mathrm{mg} / 100 \mathrm{~mL}, \text { respectively) }(\mathrm{N}=59) \text { or standard term formula } \\
\text { (energy content } 67 \mathrm{kcal} / 100 \mathrm{~mL}, \text { protein content } 1.4 \mathrm{~g} / 100 \mathrm{~mL})(\mathrm{N}=64) \text { from hospital discharge until } 6 \\
\text { months' corrected age }\end{array}$ \\
\hline Outcomes & Growth parameters and fat mass up to (at least) 12 months' corrected age \\
\hline
\end{tabular}


Roggero 2011 (Continued)

Notes

Trial was registered with Current Controlled Trials (http://www.controlledtrials.com/ISRCTN30189842).

\section{Risk of bias}

\begin{tabular}{lll}
\hline Bias & Authors' judgement & Support for judgement \\
\hline $\begin{array}{l}\text { Random sequence genera- } \\
\text { tion (selection bias) }\end{array}$ & Low risk & $\begin{array}{l}\text { Randomisation was performed by an independent investigator using comput- } \\
\text { er-generated randomisation lists. }\end{array}$ \\
\hline $\begin{array}{l}\text { Allocation concealment } \\
\text { (selection bias) }\end{array}$ & Low risk & $\begin{array}{l}\text { Randomisation was performed by an independent investigator using comput- } \\
\text { er-generated randomisation lists. }\end{array}$
\end{tabular}

Incomplete outcome data Unclear risk $\quad$ Follow-up until 12 months post term was complete.

(attrition bias)

All outcomes

Blinding of participants Unclear risk No information was provided.

and personnel (perfor-

mance bias)

All outcomes

Blinding of outcome as- Unclear risk No information was provided.

sessment (detection bias)

All outcomes

Roggero 2012

\begin{tabular}{ll}
\hline Methods & Randomised controlled trial \\
\hline Participants & 84 formula milk-fed preterm infants born 'small for gestational age' (<10th percentile) \\
\hline Interventions & $\begin{array}{l}\text { Postdischarge formula (energy content } 75 \mathrm{kcal} / 100 \mathrm{~mL}, \text { protein content } 2.0 \mathrm{~g} / 100 \mathrm{~mL}, \text { calcium and } \\
\text { phosphorus content } 100 \mathrm{mg} / 100 \mathrm{~mL} \text { and } 56 \mathrm{mg} / 100 \mathrm{~mL}, \text { respectively) }(\mathrm{N}=40) \text { or standard term formula } \\
\text { (energy content } 67 \mathrm{kcal} / 100 \mathrm{~mL}, \text { protein content } 1.4 \mathrm{~g} / 100 \mathrm{~mL})(\mathrm{N}=44) \text { from hospital discharge until } 6 \\
\text { months' corrected age }\end{array}$ \\
\hline Outcomes & Growth parameters and fat mass up to 6 months' corrected age \\
\hline Notes & $\begin{array}{l}\text { Setting: Neonatal Intensive Care Unit, Department of Maternal and Paediatric Sciences, Milan, Italy } \\
\text { (2008-2010) } \\
\text { These trialists also conducted an RCT of nutrient-enriched vs standard formula in appropriate for ges- } \\
\text { tational age infants ( } \mathrm{N}=123) \text {. These data are not yet published or available from study authors (re- } \\
\text { ferred to in conference abstract: Roggero 2011c). }\end{array}$ \\
\hline
\end{tabular}

\section{Risk of bias}

\begin{tabular}{lll}
\hline Bias & Authors' judgement & Support for judgement \\
\hline $\begin{array}{l}\text { Random sequence genera- } \\
\text { tion (selection bias) }\end{array}$ & Unclear risk & No information was provided. \\
\hline $\begin{array}{l}\text { Allocation concealment } \\
\text { (selection bias) }\end{array}$ & Unclear risk & No information was provided. \\
\hline $\begin{array}{l}\text { Incomplete outcome data } \\
\text { (attrition bias) }\end{array}$ & Low risk & Follow-up until 6 months post term was complete. \\
\hline
\end{tabular}


Roggero 2012 (Continued)

All outcomes

Blinding of participants Unclear risk No information was provided.
and personnel (perfor-
mance bias)
All outcomes

Blinding of outcome as- Unclear risk No information was provided.
sessment (detection bias)

All outcomes

Taroni 2009

\begin{tabular}{ll}
\hline Methods & Randomised controlled trial \\
\hline Participants & $\begin{array}{l}27 \text { formula milk-fed preterm infants, birth weight }<1500 \mathrm{~g} \text { or gestation at birth }<33 \text { weeks, 'small for } \\
\text { gestational age' (< 10th percentile) }\end{array}$ \\
\hline Interventions & $\begin{array}{l}\text { Postdischarge formula (energy content } 75 \mathrm{kcal} / 100 \mathrm{~mL}, \text { protein content } 2.0 \mathrm{~g} / 100 \mathrm{~mL}, \mathrm{calcium} \text { and } \\
\text { phosphorus content } 100 \mathrm{mg} / 100 \mathrm{~mL} \text { and } 56 \mathrm{mg} / 100 \mathrm{~mL}, \text { respectively) } \mathrm{N}=14) \text { or standard term formula } \\
\text { (energy content } 67 \mathrm{kcal} / 100 \mathrm{~mL}, \text { protein content } 1.4 \mathrm{~g} / 100 \mathrm{~mL})(\mathrm{N}=13) \text { from hospital discharge until } 1 \\
\text { month corrected age }\end{array}$ \\
\hline Outcomes & Growth parameters and fat mass up to 1 month corrected age \\
\hline Notes & Setting: 4 Italian neonatal units (2008-2009)
\end{tabular}

\section{Risk of bias}

\begin{tabular}{|c|c|c|}
\hline Bias & Authors' judgement & Support for judgement \\
\hline $\begin{array}{l}\text { Random sequence genera- } \\
\text { tion (selection bias) }\end{array}$ & Low risk & Random sequence was pre-prepared. \\
\hline $\begin{array}{l}\text { Allocation concealment } \\
\text { (selection bias) }\end{array}$ & Unclear risk & No information was provided. \\
\hline $\begin{array}{l}\text { Incomplete outcome data } \\
\text { (attrition bias) } \\
\text { All outcomes }\end{array}$ & Low risk & Follow-up until 1 month post term was complete. \\
\hline $\begin{array}{l}\text { Blinding of participants } \\
\text { and personnel (perfor- } \\
\text { mance bias) } \\
\text { All outcomes }\end{array}$ & Unclear risk & No information was provided. \\
\hline $\begin{array}{l}\text { Blinding of outcome as- } \\
\text { sessment (detection bias) } \\
\text { All outcomes }\end{array}$ & Unclear risk & No information was provided. \\
\hline
\end{tabular}

PMA: postmenstrual age.

RCT: randomised controlled trial.

VLBW: very low birth weight. 
Characteristics of excluded studies [ordered by study ID]

\begin{tabular}{ll}
\hline Study & Reason for exclusion \\
\hline Amesz 2010 & The protein content of both formula milks was $\leq 1.7 \mathrm{~g} / 100 \mathrm{~mL}$. \\
\hline Bernbaum 1989 & The energy content of both formula milks was $<70 \mathrm{kcal} / 100 \mathrm{~mL}$. \\
\hline Bhatia 1991 & The protein content of both formula milks was $\leq 1.7 \mathrm{~g} / 100 \mathrm{~mL}$. \\
\hline Brunton 1998 & Both formula milks were calorie-enriched $(90 \mathrm{kcal} / 100 \mathrm{~mL})$. \\
\hline Chan 1994 & The energy content of both formula milks was $<70 \mathrm{kcal} / 100 \mathrm{~mL}$. \\
\hline Cooper 1985 & The energy content of both formula milks was $<70 \mathrm{kcal} / 100 \mathrm{~mL}$. \\
\hline Friel 1993 & The energy content of both formula milks was $<70 \mathrm{kcal} / 100 \mathrm{~mL}$. \\
\hline Lapillonne 2004 & Both formula milks were calorie-enriched $(81 \mathrm{kcal} / 100 \mathrm{~mL})$ and protein-enriched $(>2.0 \mathrm{~g} / 100 \mathrm{~mL})$. \\
\hline Wheeler 1996 & The energy content of both formula milks was $<70 \mathrm{kcal} / 100 \mathrm{~mL}$. \\
\hline
\end{tabular}

\section{Characteristics of studies awaiting assessment [ordered by study ID]}

Ekcharoen 2015

\begin{tabular}{ll}
\hline Methods & Randomised controlled trial \\
\hline Participants & $\begin{array}{l}\text { Preterm infants who had postconceptional age } 35 \text { to } 36 \text { weeks and weight } 1.8 \text { to } 3 \text { kg at hospital } \\
\text { discharge }\end{array}$ \\
\hline Interventions & Postdischarge formula vs high-energy, high-protein, medium-chain triglyceride-containing formula \\
\hline Outcomes & Growth rate at days 28, 56 and 84 after hospital discharge \\
\hline Notes & Abstract only; full-text article not available (study authors contacted September 2016) \\
\hline
\end{tabular}

\section{DATA AND ANALYSES}

\section{Comparison 1. Postdischarge formula versus standard term formula}

\begin{tabular}{lllll}
\hline Outcome or subgroup title & No. of studies & $\begin{array}{l}\text { No. of partici- } \\
\text { pants }\end{array}$ & Statistical method & Effect size \\
\hline $\begin{array}{l}1 \text { Growth rates during trial peri- } \\
\text { od }\end{array}$ & 1 & & $\begin{array}{l}\text { Mean Difference (IV, Fixed, 95\% } \\
\text { Cl) }\end{array}$ & Subtotals only \\
\hline $\begin{array}{llll}1.1 \text { Weight gain }(\mathrm{g} / \mathrm{kg} / \mathrm{d}) \\
\end{array}$ & 1 & 33 & $\begin{array}{l}\text { Mean Difference (IV, Fixed, 95\% } \\
\text { Cl) }\end{array}$ & $0.0[-1.37,1.37]$ \\
\hline
\end{tabular}




\begin{tabular}{|c|c|c|c|c|}
\hline Outcome or subgroup title & No. of studies & $\begin{array}{l}\text { No. of partici- } \\
\text { pants }\end{array}$ & Statistical method & Effect size \\
\hline 1.2 Linear growth (mm/wk) & 1 & 33 & $\begin{array}{l}\text { Mean Difference (IV, Fixed, 95\% } \\
\mathrm{CI} \text { ) }\end{array}$ & $0.0[-1.07,1.07]$ \\
\hline $\begin{array}{l}1.3 \text { Head circumference }(\mathrm{mm} / \\
\text { wk) }\end{array}$ & 1 & 33 & $\begin{array}{l}\text { Mean Difference (IV, Fixed, 95\% } \\
\mathrm{CI} \text { ) }\end{array}$ & $0.0[-0.68,0.68]$ \\
\hline 2 Weight (grams) & 7 & & $\begin{array}{l}\text { Mean Difference (IV, Fixed, 95\% } \\
\mathrm{CI} \text { ) }\end{array}$ & Subtotals only \\
\hline 2.13-4 months post term & 6 & 523 & $\begin{array}{l}\text { Mean Difference (IV, Fixed, 95\% } \\
\mathrm{CI} \text { ) }\end{array}$ & $\begin{array}{l}-7.45[-141.84 \\
126.93]\end{array}$ \\
\hline 2.26 months post term & 7 & 576 & $\begin{array}{l}\text { Mean Difference (IV, Fixed, 95\% } \\
\mathrm{CI} \text { ) }\end{array}$ & $\begin{array}{l}35.54[-113.71 \\
184.78]\end{array}$ \\
\hline 2.39 months post term & 4 & 347 & $\begin{array}{l}\text { Mean Difference (IV, Fixed, 95\% } \\
\mathrm{CI})\end{array}$ & $\begin{array}{l}244.09[16.95 \\
471.23]\end{array}$ \\
\hline 2.412 months post term & 4 & 314 & $\begin{array}{l}\text { Mean Difference (IV, Fixed, 95\% } \\
\mathrm{CI} \text { ) }\end{array}$ & $\begin{array}{l}-14.87[-243.18 \\
213.43]\end{array}$ \\
\hline $2.518-24$ months post term & 1 & 192 & $\begin{array}{l}\text { Mean Difference (IV, Fixed, 95\% } \\
\mathrm{CI} \text { ) }\end{array}$ & $\begin{array}{l}100.0[-246.90 \\
446.90]\end{array}$ \\
\hline 3 Crown-heel length (mm) & 7 & & $\begin{array}{l}\text { Mean Difference (IV, Fixed, 95\% } \\
\mathrm{CI} \text { ) }\end{array}$ & Subtotals only \\
\hline 3.13-4 months post term & 6 & 523 & $\begin{array}{l}\text { Mean Difference (IV, Fixed, 95\% } \\
\mathrm{CI} \text { ) }\end{array}$ & $2.45[-2.01,6.90]$ \\
\hline 3.26 months post term & 7 & 576 & $\begin{array}{l}\text { Mean Difference (IV, Fixed, 95\% } \\
\mathrm{CI} \text { ) }\end{array}$ & $2.12[-2.16,6.41]$ \\
\hline 3.39 months post term & 4 & 347 & $\begin{array}{l}\text { Mean Difference (IV, Fixed, 95\% } \\
\mathrm{CI} \text { ) }\end{array}$ & $7.33[1.80,12.87]$ \\
\hline 3.412 months post term & 4 & 314 & $\begin{array}{l}\text { Mean Difference (IV, Fixed, 95\% } \\
\mathrm{CI} \text { ) }\end{array}$ & $-0.66[-6.43,5.10]$ \\
\hline $3.518-24$ months post term & 1 & 192 & $\begin{array}{l}\text { Mean Difference (IV, Fixed, 95\% } \\
\mathrm{CI} \text { ) }\end{array}$ & $9.0[0.32,17.68]$ \\
\hline 4 Head circumference (mm) & 7 & & $\begin{array}{l}\text { Mean Difference (IV, Fixed, 95\% } \\
\mathrm{CI})\end{array}$ & Subtotals only \\
\hline 4.1 3-4 months post term & 6 & 523 & $\begin{array}{l}\text { Mean Difference (IV, Fixed, 95\% } \\
\mathrm{CI})\end{array}$ & $-0.30[-2.86,2.26]$ \\
\hline 4.26 months post term & 7 & 576 & $\begin{array}{l}\text { Mean Difference (IV, Fixed, 95\% } \\
\mathrm{CI} \text { ) }\end{array}$ & $2.28[-0.28,4.83]$ \\
\hline 4.39 months post term & 4 & 347 & $\begin{array}{l}\text { Mean Difference (IV, Fixed, 95\% } \\
\mathrm{CI} \text { ) }\end{array}$ & $0.16[-3.21,3.53]$ \\
\hline
\end{tabular}




\begin{tabular}{|c|c|c|c|c|}
\hline Outcome or subgroup title & No. of studies & $\begin{array}{l}\text { No. of partici- } \\
\text { pants }\end{array}$ & Statistical method & Effect size \\
\hline 4.412 months post term & 4 & 314 & $\begin{array}{l}\text { Mean Difference (IV, Fixed, 95\% } \\
\mathrm{CI})\end{array}$ & $2.11[-1.52,5.75]$ \\
\hline $4.518-24$ months post term & 1 & 192 & $\begin{array}{l}\text { Mean Difference (IV, Fixed, 95\% } \\
\mathrm{CI} \text { ) }\end{array}$ & $-3.0[-8.24,2.24]$ \\
\hline 5 Development & 1 & & $\begin{array}{l}\text { Mean Difference (IV, Fixed, 95\% } \\
\mathrm{CI} \text { ) }\end{array}$ & Subtotals only \\
\hline $\begin{array}{l}\text { 5.1 Bayley Scales of Infant De- } \\
\text { velopment II: Mental Develop- } \\
\text { ment Index }\end{array}$ & 1 & 184 & $\begin{array}{l}\text { Mean Difference (IV, Fixed, 95\% } \\
\mathrm{CI} \text { ) }\end{array}$ & $0.90[-3.24,5.04]$ \\
\hline $\begin{array}{l}5.2 \text { Bayley Scales of Infant De- } \\
\text { velopment II: Psychomotor De- } \\
\text { velopment Index }\end{array}$ & 1 & 184 & $\begin{array}{l}\text { Mean Difference (IV, Fixed, 95\% } \\
\mathrm{CI})\end{array}$ & $2.70[-1.28,6.68]$ \\
\hline 6 Bone mineralisation & 3 & & $\begin{array}{l}\text { Mean Difference (IV, Fixed, 95\% } \\
\mathrm{CI} \text { ) }\end{array}$ & Subtotals only \\
\hline $\begin{array}{l}6.1 \text { Bone area at } 2 \text { months post } \\
\text { term }\left(\mathrm{cm}^{2}\right)\end{array}$ & 1 & 33 & $\begin{array}{l}\text { Mean Difference (IV, Fixed, 95\% } \\
\mathrm{CI} \text { ) }\end{array}$ & $7.0[-15.46,29.46]$ \\
\hline $\begin{array}{l}6.2 \text { Bone mineral content at } 2 \\
\text { months post term (grams) }\end{array}$ & 1 & 33 & $\begin{array}{l}\text { Mean Difference (IV, Fixed, 95\% } \\
\mathrm{CI} \text { ) }\end{array}$ & $3.20[-4.73,11.13]$ \\
\hline $\begin{array}{l}6.3 \text { Bone 'speed of sound' as- } \\
\text { sessed on ultrasonography at } 6 \\
\text { months post term }(\mathrm{mm} / \mathrm{s})\end{array}$ & 1 & 20 & $\begin{array}{l}\text { Mean Difference (IV, Fixed, 95\% } \\
\mathrm{CI})\end{array}$ & $45.0[-18.48,108.48]$ \\
\hline $\begin{array}{l}\text { 6.4 Bone specific serum alkaline } \\
\text { phosphatase at } 6 \text { months post } \\
\text { term (units/L) }\end{array}$ & 1 & 20 & $\begin{array}{l}\text { Mean Difference (IV, Fixed, 95\% } \\
\mathrm{CI})\end{array}$ & $-9.0[-42.01,24.01]$ \\
\hline $\begin{array}{l}6.5 \text { Bone width at } 9 \text { months post } \\
\text { term }(\mathrm{cm})\end{array}$ & 1 & 31 & $\begin{array}{l}\text { Mean Difference (IV, Fixed, 95\% } \\
\mathrm{CI} \text { ) }\end{array}$ & $0.05[-0.01,0.11]$ \\
\hline $\begin{array}{l}6.6 \text { Bone mineral content at } 9 \\
\text { months post term }(\mathrm{mg} / \mathrm{cm})\end{array}$ & 1 & 31 & $\begin{array}{l}\text { Mean Difference (IV, Fixed, 95\% } \\
\mathrm{CI} \text { ) }\end{array}$ & $20.60[7.78,33.42]$ \\
\hline
\end{tabular}

\section{Analysis 1.1. Comparison 1 Postdischarge formula versus standard} term formula, Outcome 1 Growth rates during trial period.

\begin{tabular}{|c|c|c|c|c|c|c|c|}
\hline \multirow[t]{2}{*}{ Study or subgroup } & \multicolumn{2}{|c|}{$\begin{array}{c}\text { Post-dis- } \\
\text { charge formula }\end{array}$} & \multicolumn{2}{|c|}{ Term formula } & \multirow{2}{*}{$\begin{array}{c}\text { Mean Difference } \\
\text { Fixed, } 95 \% \mathrm{Cl}\end{array}$} & \multirow[t]{2}{*}{ Weight } & \multirow{2}{*}{$\begin{array}{l}\text { Mean Difference } \\
\text { Fixed, } 95 \% \mathrm{Cl} \\
\end{array}$} \\
\hline & $\mathbf{N}$ & Mean(SD) & $\mathbf{N}$ & Mean(SD) & & & \\
\hline \multicolumn{8}{|l|}{ 1.1.1 Weight gain $(\mathrm{g} / \mathrm{kg} / \mathrm{d})$} \\
\hline De Curtis 2002 & 16 & $10(2)$ & 17 & $10(2)$ & & $100 \%$ & $0[-1.37,1.37]$ \\
\hline Subtotal $* \star \star$ & 16 & & 17 & & & $100 \%$ & $0[-1.37,1.37]$ \\
\hline \multicolumn{8}{|l|}{ Heterogeneity: Not applicable } \\
\hline & & & Favou & m formula & $\begin{array}{ll}1 & 1 \\
-1 & -0.5\end{array}$ & Favours & scharge for \\
\hline
\end{tabular}




\begin{tabular}{|c|c|c|c|c|c|c|c|}
\hline \multirow[t]{2}{*}{ Study or subgroup } & \multicolumn{2}{|c|}{$\begin{array}{l}\text { Post-dis- } \\
\text { charge formula }\end{array}$} & \multicolumn{2}{|c|}{ Term formula } & \multirow{2}{*}{$\begin{array}{c}\text { Mean Difference } \\
\text { Fixed, } 95 \% \mathrm{Cl} \\
\end{array}$} & \multirow[t]{2}{*}{ Weight } & \multirow{2}{*}{$\begin{array}{l}\text { Mean Difference } \\
\text { Fixed, } 95 \% \mathrm{Cl}\end{array}$} \\
\hline & $\mathbf{N}$ & Mean(SD) & $\mathbf{N}$ & Mean(SD) & & & \\
\hline \multicolumn{8}{|c|}{ 1.1.2 Linear growth $(\mathrm{mm} / \mathrm{wk})$} \\
\hline De Curtis 2002 & 16 & $10(1)$ & 17 & $10(2)$ & & $100 \%$ & $0[-1.07,1.07]$ \\
\hline Subtotal $\star \star \star$ & 16 & & 17 & & & $100 \%$ & $0[-1.07,1.07]$ \\
\hline \multicolumn{8}{|c|}{ Heterogeneity: Not applicable } \\
\hline \multicolumn{8}{|c|}{ Test for overall effect: Not applicable } \\
\hline \multicolumn{8}{|c|}{ 1.1.3 Head circumference (mm/wk) } \\
\hline De Curtis 2002 & 16 & $6(1)$ & 17 & $6(1)$ & 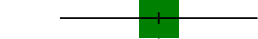 & $100 \%$ & $0[-0.68,0.68]$ \\
\hline Subtotal $* \star \star$ & 16 & & 17 & & & $100 \%$ & $0[-0.68,0.68]$ \\
\hline \multicolumn{8}{|c|}{ Heterogeneity: Not applicable } \\
\hline \multicolumn{8}{|c|}{ Test for overall effect: Not applicable } \\
\hline \multicolumn{8}{|c|}{ Test for subgroup differences: Not applicable } \\
\hline
\end{tabular}

Analysis 1.2. Comparison 1 Postdischarge formula versus standard term formula, Outcome 2 Weight (grams).

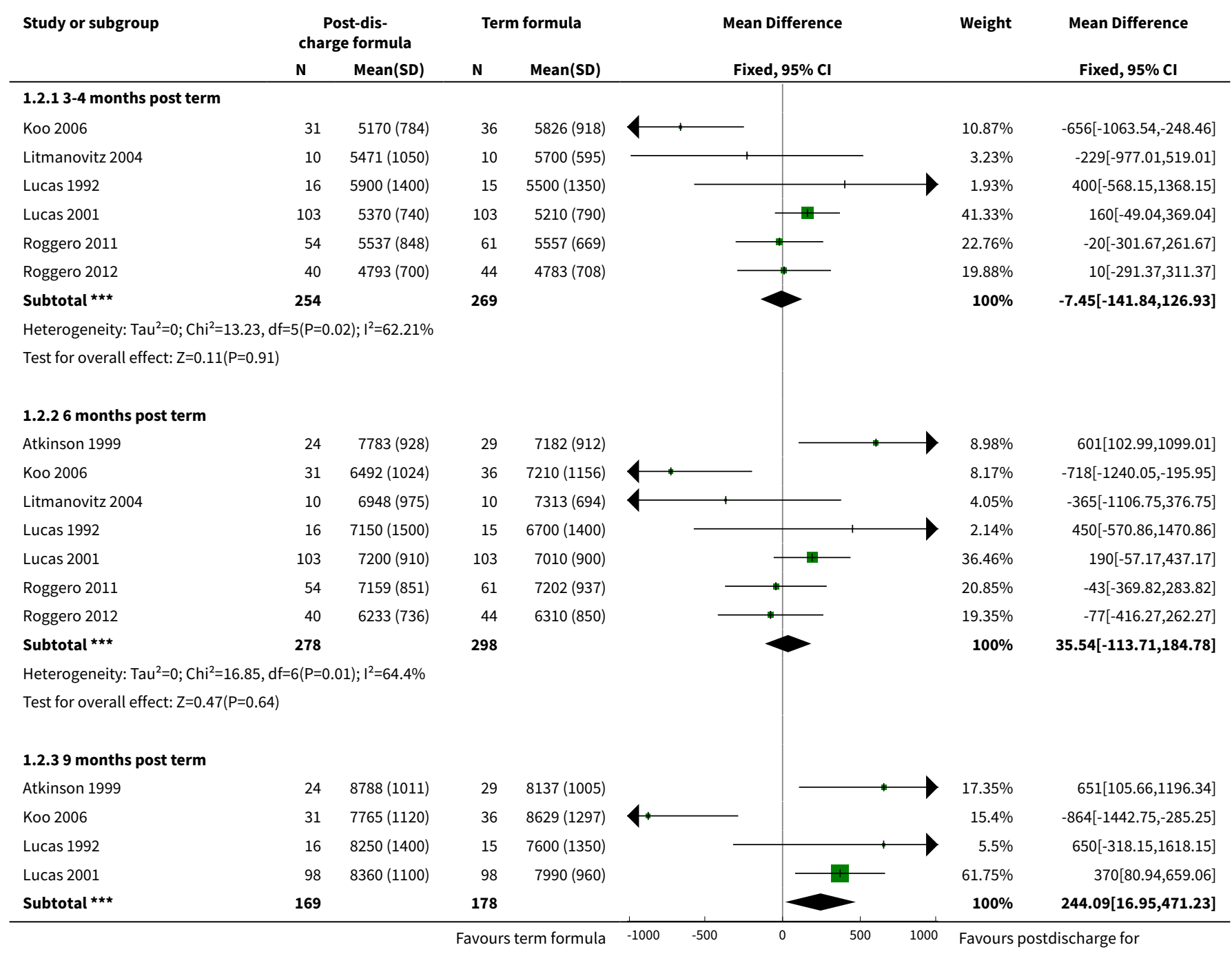




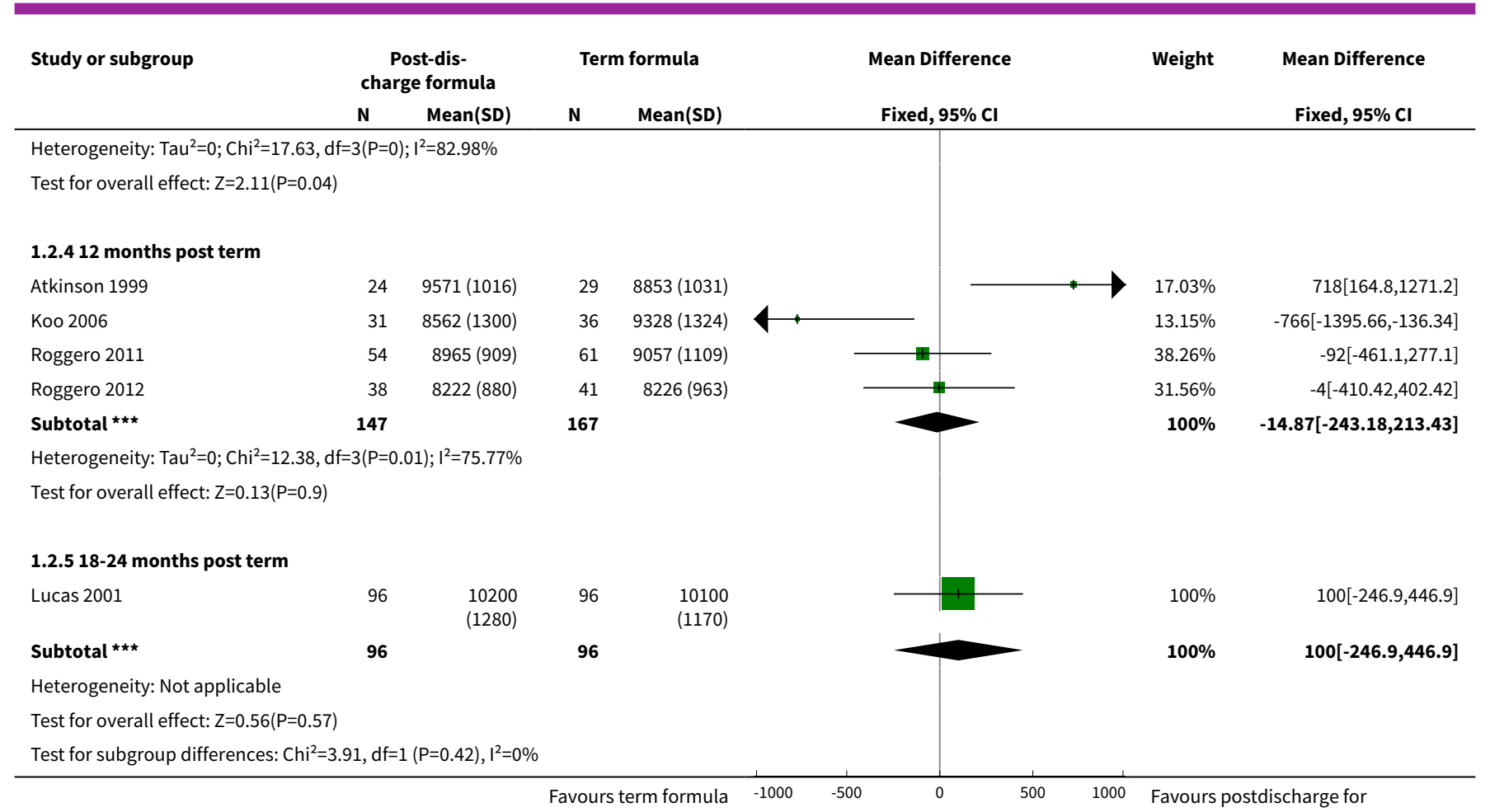

\section{Analysis 1.3. Comparison 1 Postdischarge formula versus standard term formula, Outcome 3 Crown-heel length $(\mathrm{mm})$.}

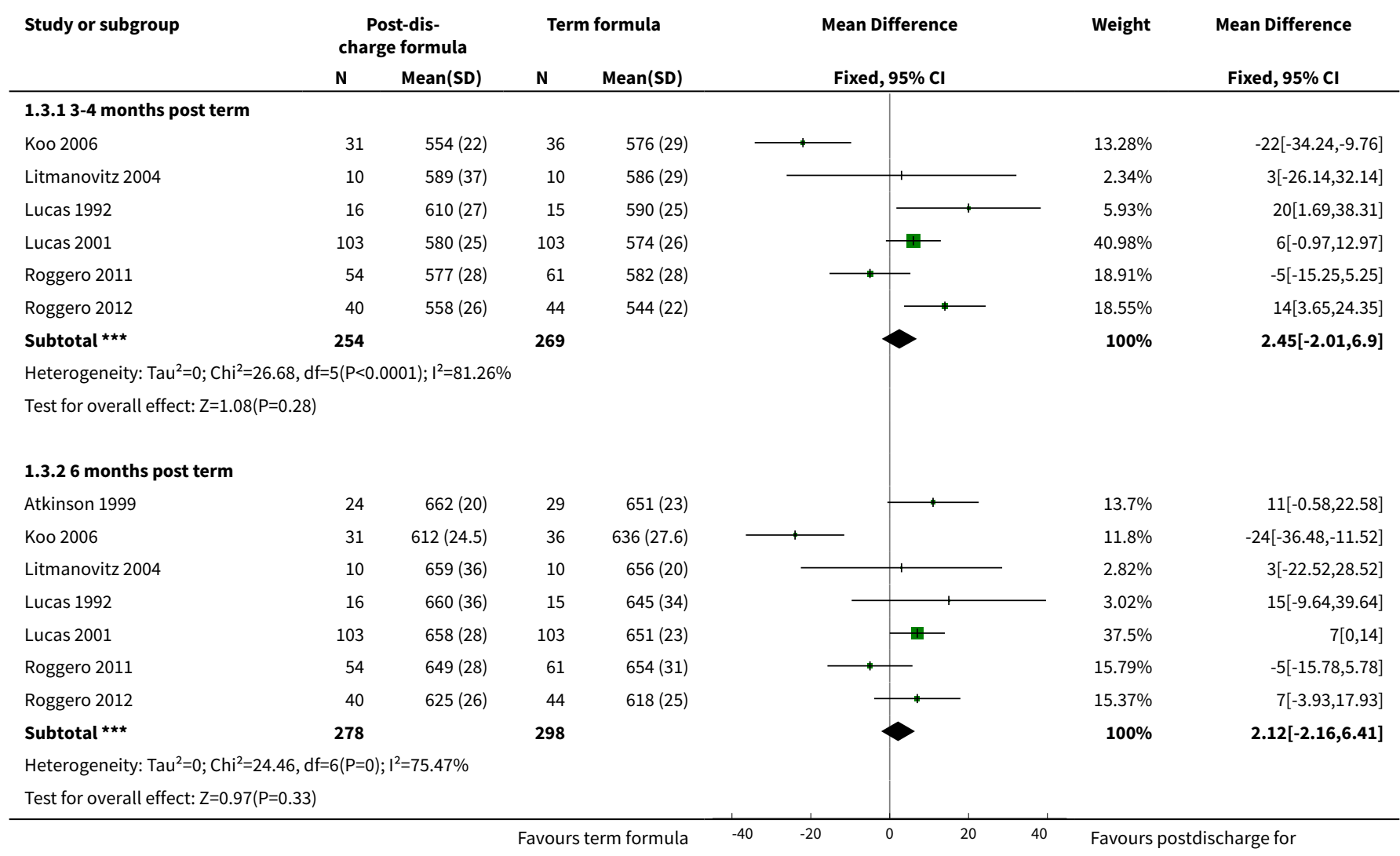




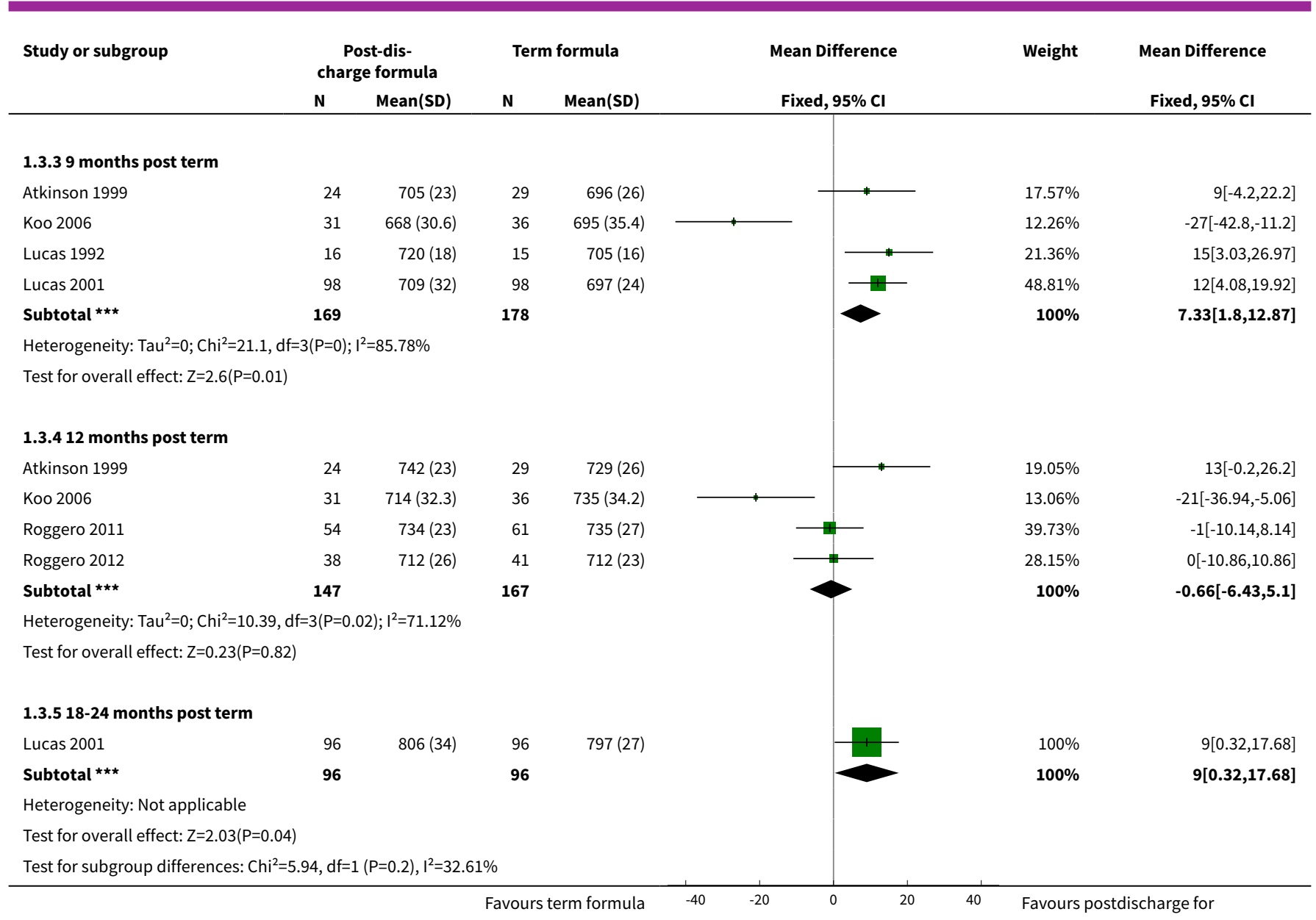

Analysis 1.4. Comparison 1 Postdischarge formula versus standard term formula, Outcome 4 Head circumference (mm).

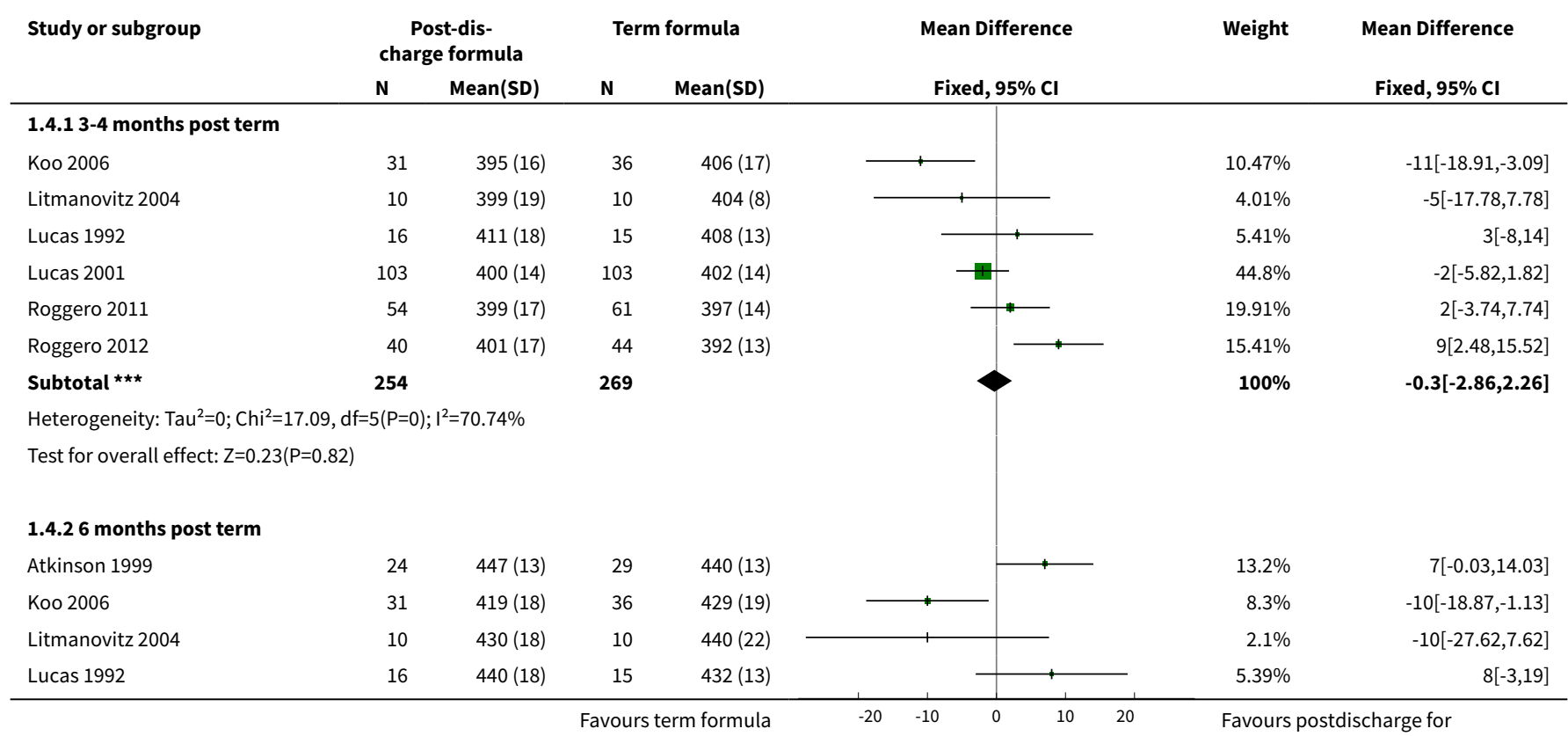

Nutrient-enriched formula versus standard formula for preterm infants following hospital discharge (Review) 


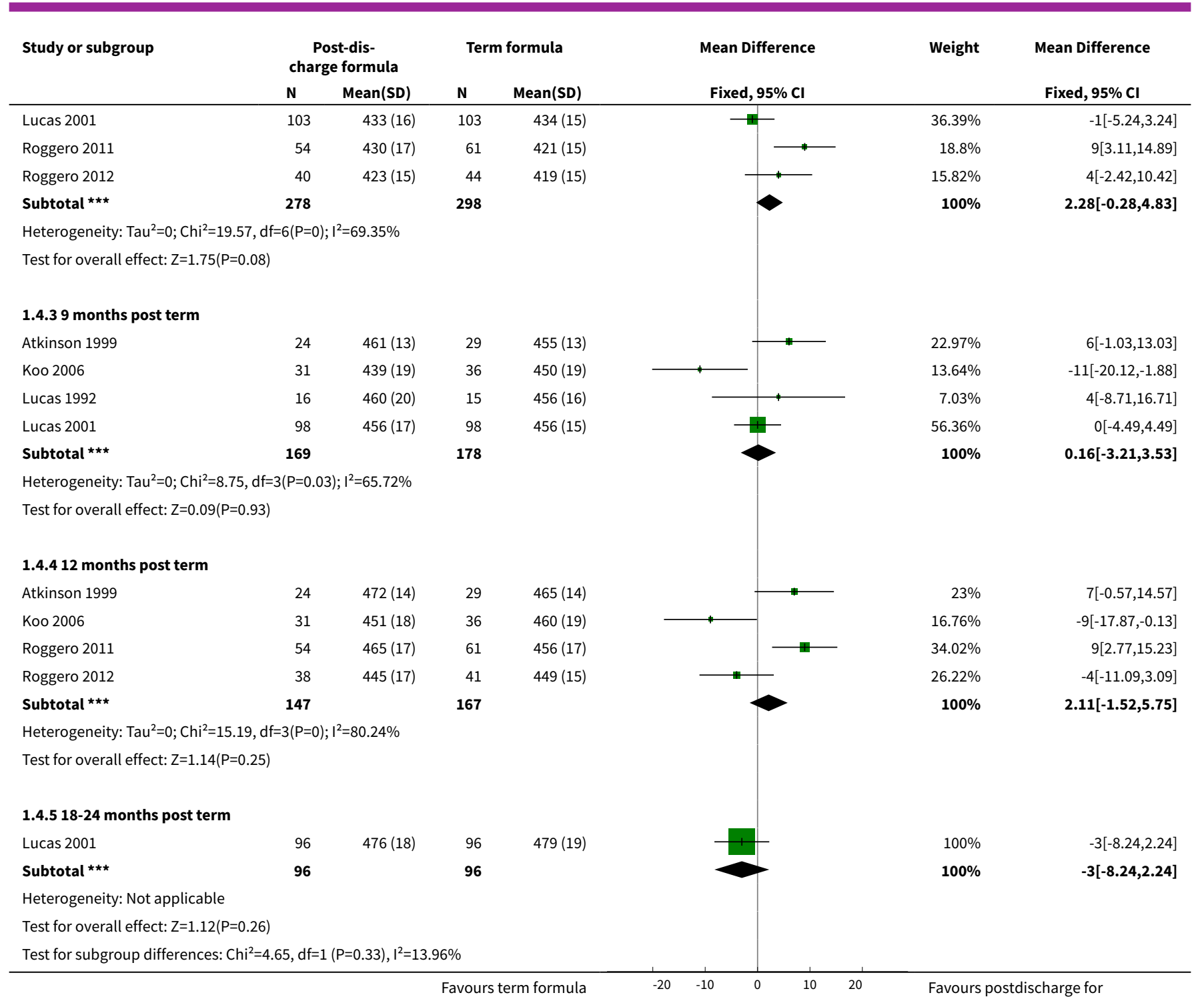

\section{Analysis 1.5. Comparison 1 Postdischarge formula versus standard term formula, Outcome 5 Development.}

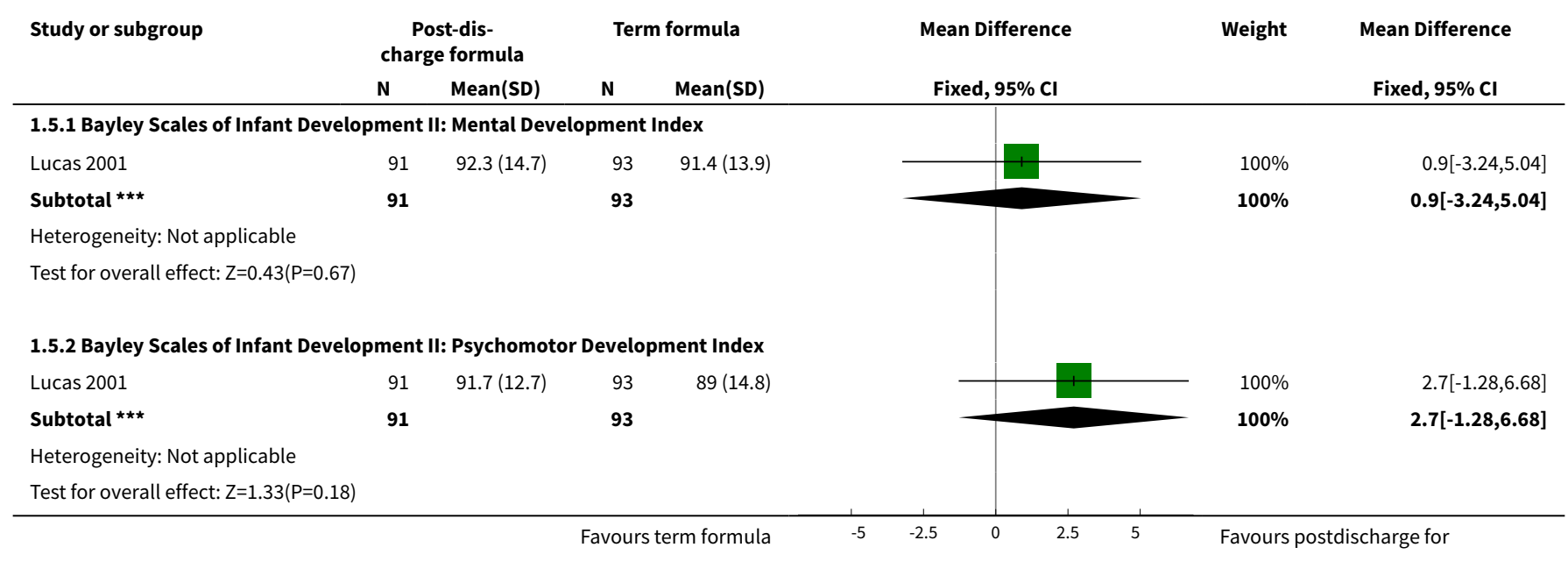




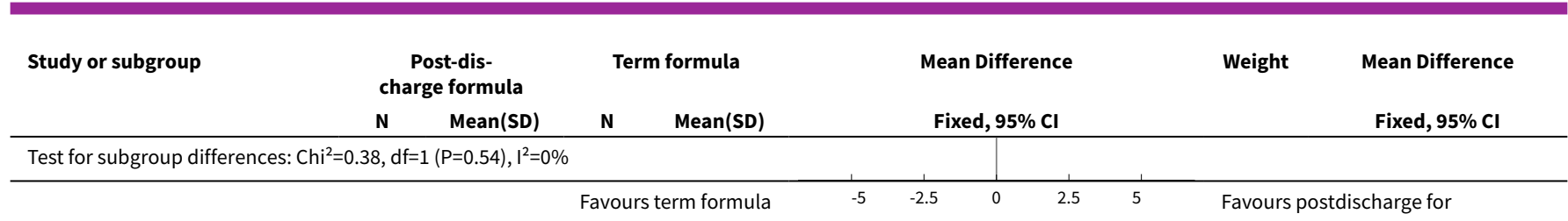

Analysis 1.6. Comparison 1 Postdischarge formula versus standard term formula, Outcome 6 Bone mineralisation.

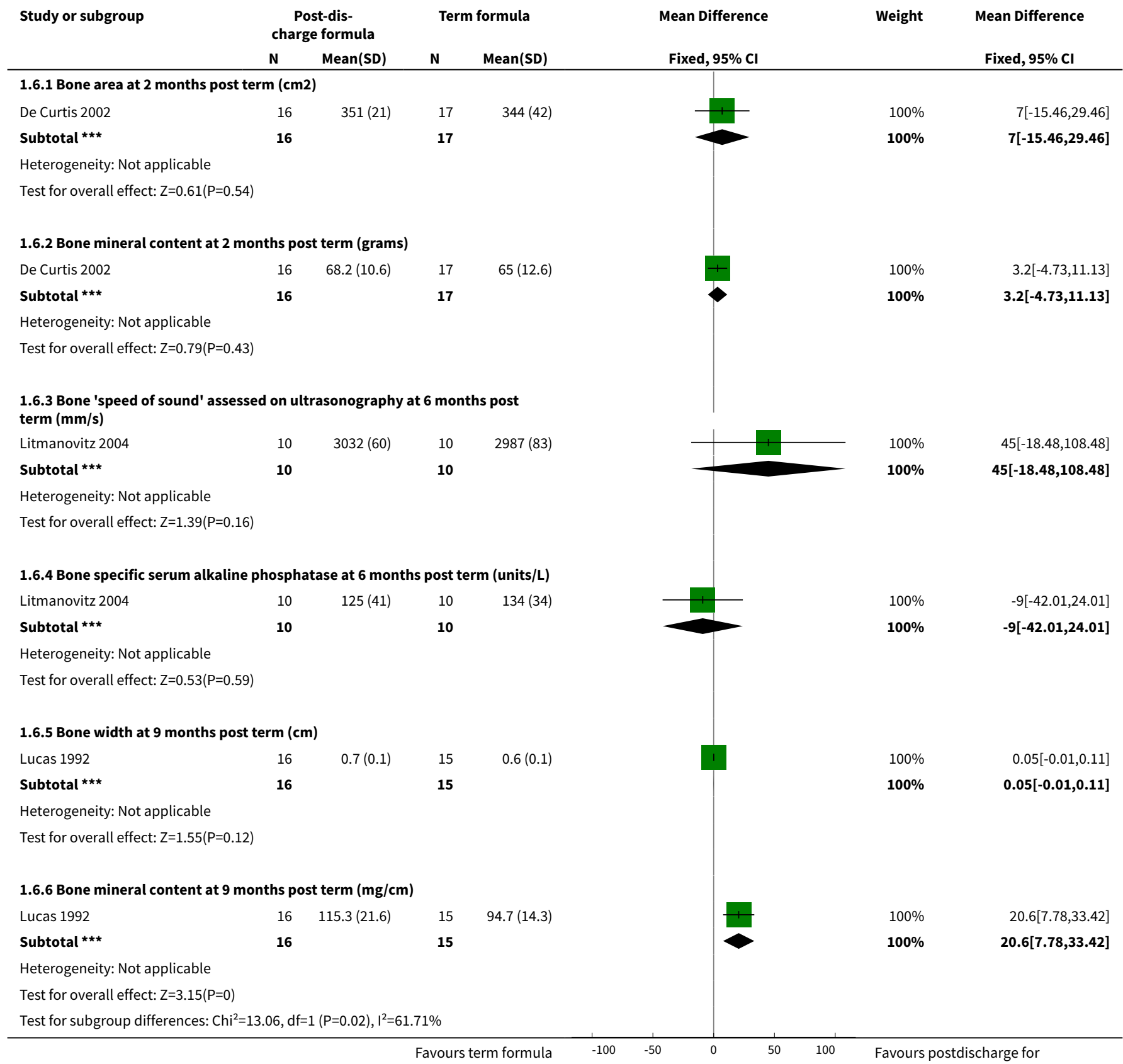


Comparison 2. Preterm formula versus standard term formula

\begin{tabular}{|c|c|c|c|c|}
\hline Outcome or subgroup title & No. of studies & $\begin{array}{l}\text { No. of partici- } \\
\text { pants }\end{array}$ & Statistical method & Effect size \\
\hline $\begin{array}{l}1 \text { Growth rates during trial } \\
\text { period }\end{array}$ & 1 & & Mean Difference (IV, Fixed, 95\% CI) & Subtotals only \\
\hline 1.1 Weight gain $(\mathrm{g} / \mathrm{d})$ & 1 & 42 & Mean Difference (IV, Fixed, 95\% CI) & $3.70[-0.16,7.56]$ \\
\hline 1.2 Linear growth (mm/wk) & 1 & 42 & Mean Difference (IV, Fixed, 95\% CI) & $1.0[0.09,1.91]$ \\
\hline $\begin{array}{l}\text { 1.3 Head circumference } \\
(\mathrm{mm} / \mathrm{wk})\end{array}$ & 1 & 42 & Mean Difference (IV, Fixed, 95\% CI) & $0.5[-0.04,1.04]$ \\
\hline 2 Weight (grams) & 5 & & Mean Difference (IV, Fixed, 95\% CI) & Subtotals only \\
\hline 2.1 3-4 months post term & 3 & 130 & Mean Difference (IV, Fixed, 95\% CI) & $\begin{array}{l}74.41[-267.10 \\
415.93]\end{array}$ \\
\hline 2.26 months post term & 4 & 273 & Mean Difference (IV, Fixed, 95\% CI) & $\begin{array}{l}74.60[-164.73 \\
313.92]\end{array}$ \\
\hline 2.39 months post term & 1 & 59 & Mean Difference (IV, Fixed, 95\% CI) & $\begin{array}{l}112.0[-482.69 \\
706.69]\end{array}$ \\
\hline 2.412 months post term & 4 & 265 & Mean Difference (IV, Fixed, 95\% CI) & $\begin{array}{l}539.48[255.03 \\
823.92]\end{array}$ \\
\hline 2.518 months post term & 2 & 162 & Mean Difference (IV, Fixed, 95\% CI) & $\begin{array}{l}490.81[142.19 \\
839.44]\end{array}$ \\
\hline 3 Crown-heel length (mm) & 5 & & Mean Difference (IV, Fixed, 95\% CI) & Subtotals only \\
\hline 3.1 3-4 months post term & 3 & 130 & Mean Difference (IV, Fixed, 95\% CI) & $-2.27[-13.09,8.56]$ \\
\hline 3.26 months post term & 3 & 160 & Mean Difference (IV, Fixed, 95\% CI) & $1.83[-6.25,9.92]$ \\
\hline 3.39 months post term & 1 & 59 & Mean Difference (IV, Fixed, 95\% CI) & $-3.0[-17.03,11.03]$ \\
\hline 3.412 months post term & 3 & 152 & Mean Difference (IV, Fixed, 95\% CI) & $5.13[-4.23,14.49]$ \\
\hline 3.518 months post term & 2 & 162 & Mean Difference (IV, Fixed, 95\% CI) & $11.00[1.89,20.11]$ \\
\hline 4 Head circumference (mm) & 5 & & Mean Difference (IV, Fixed, 95\% CI) & Subtotals only \\
\hline 4.1 3-4 months post term & 3 & 130 & Mean Difference (IV, Fixed, 95\% CI) & $3.61[-2.09,9.31]$ \\
\hline 4.26 months post term & 3 & 160 & Mean Difference (IV, Fixed, 95\% CI) & $5.82[1.32,10.32]$ \\
\hline 4.39 months post term & 1 & 59 & Mean Difference (IV, Fixed, 95\% CI) & $8.0[0.85,15.15]$ \\
\hline 4.412 months post term & 3 & 152 & Mean Difference (IV, Fixed, 95\% CI) & $6.07[1.07,11.06]$ \\
\hline 4.518 months post term & 2 & 162 & Mean Difference (IV, Fixed, 95\% CI) & $5.42[0.69,10.14]$ \\
\hline 5 Development & 2 & & Mean Difference (IV, Fixed, 95\% CI) & Subtotals only \\
\hline
\end{tabular}




\begin{tabular}{lllll}
\hline Outcome or subgroup title & No. of studies & $\begin{array}{l}\text { No. of partici- } \\
\text { pants }\end{array}$ & Statistical method & Effect size \\
\hline $\begin{array}{l}5.1 \text { Bayley Scales of Infant } \\
\text { Development II: Mental De- } \\
\text { velopment Index }\end{array}$ & 2 & 143 & Mean Difference (IV, Fixed, 95\% Cl) & $-1.44[-6.22,3.35]$ \\
\hline $\begin{array}{l}5.2 \text { Bayley Scales of Infant } \\
\text { Development II: Psychomo- } \\
\text { tor Development Index }\end{array}$ & 2 & 143 & Mean Difference (IV, Fixed, 95\% Cl) & $-1.13[-4.19,1.93]$ \\
\hline
\end{tabular}

\section{Analysis 2.1. Comparison 2 Preterm formula versus standard term formula, Outcome 1 Growth rates during trial period.}

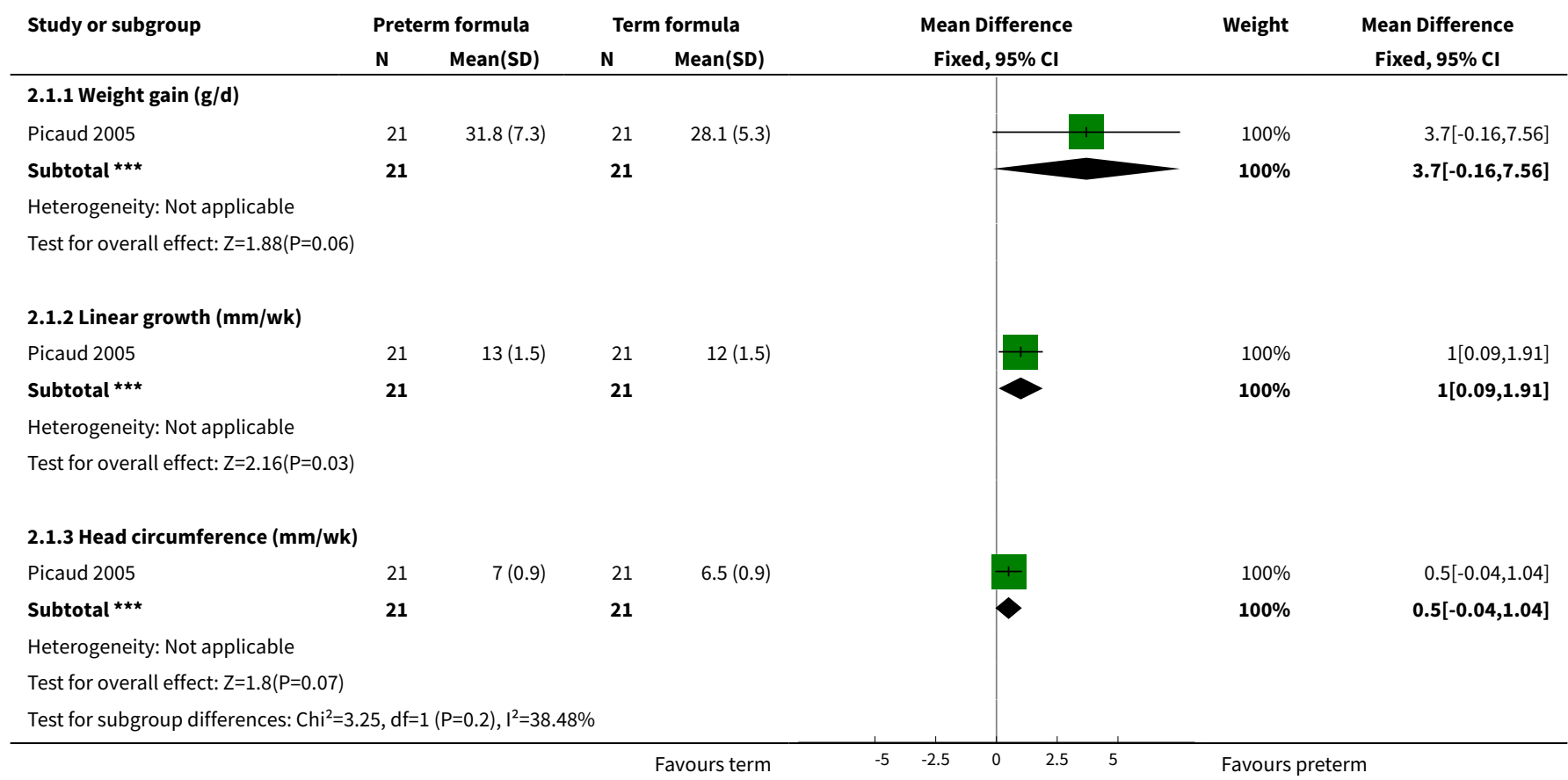

Analysis 2.2. Comparison 2 Preterm formula versus standard term formula, Outcome 2 Weight (grams).

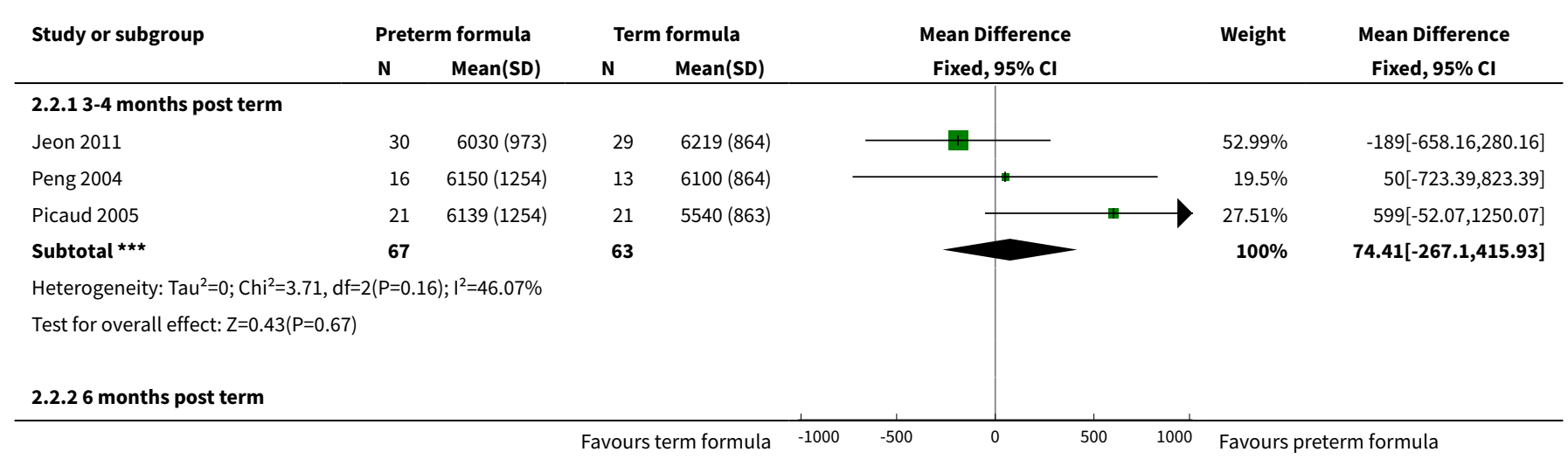




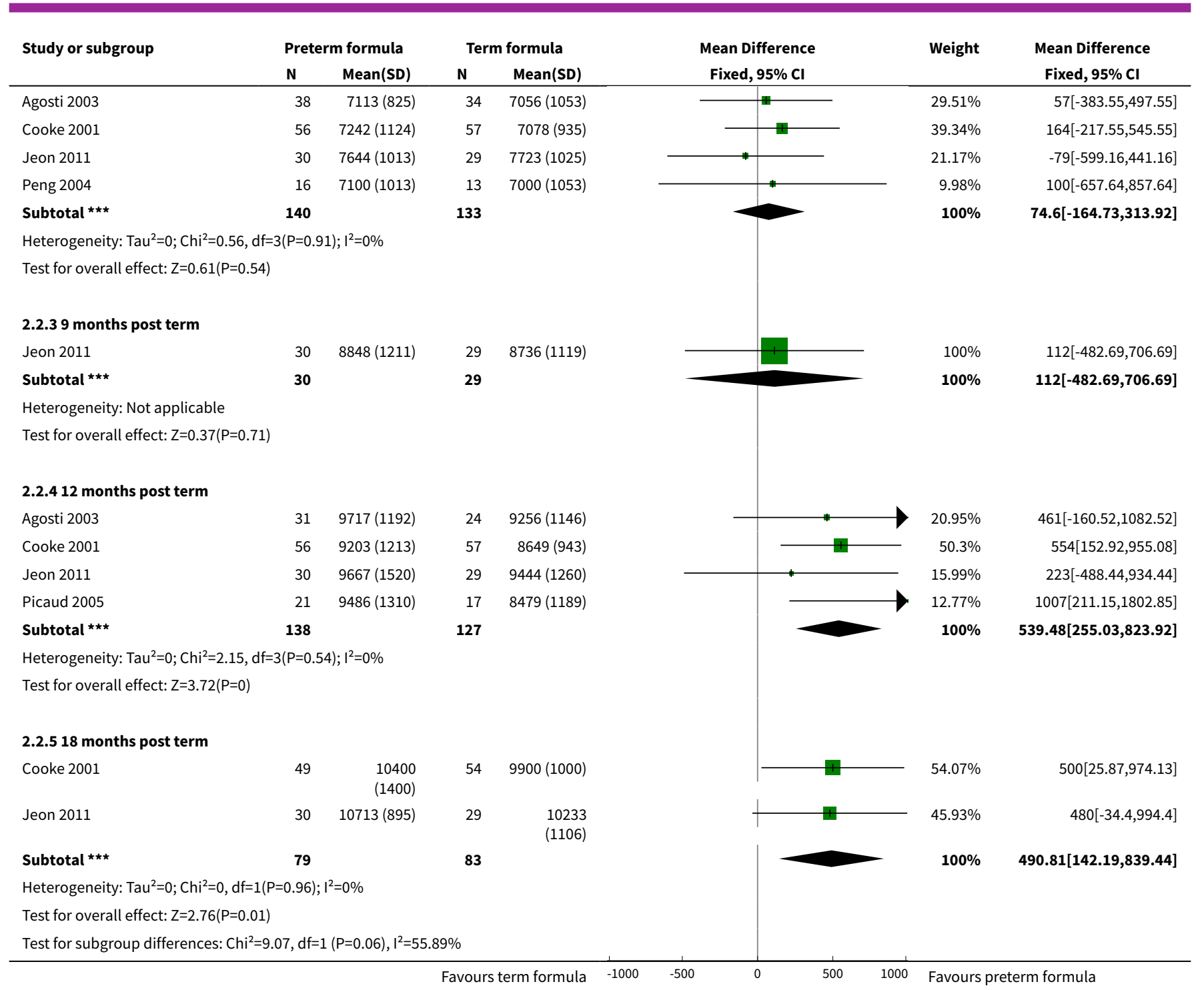

Analysis 2.3. Comparison 2 Preterm formula versus standard term formula, Outcome 3 Crown-heel length (mm).

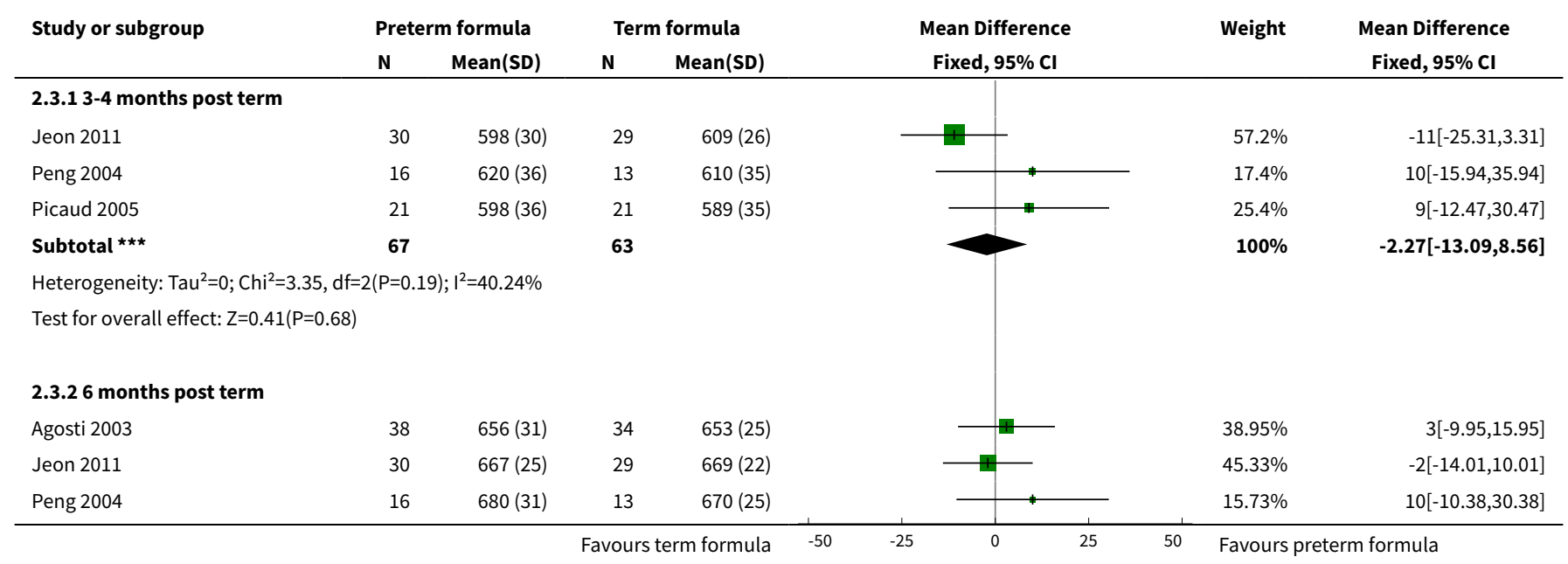




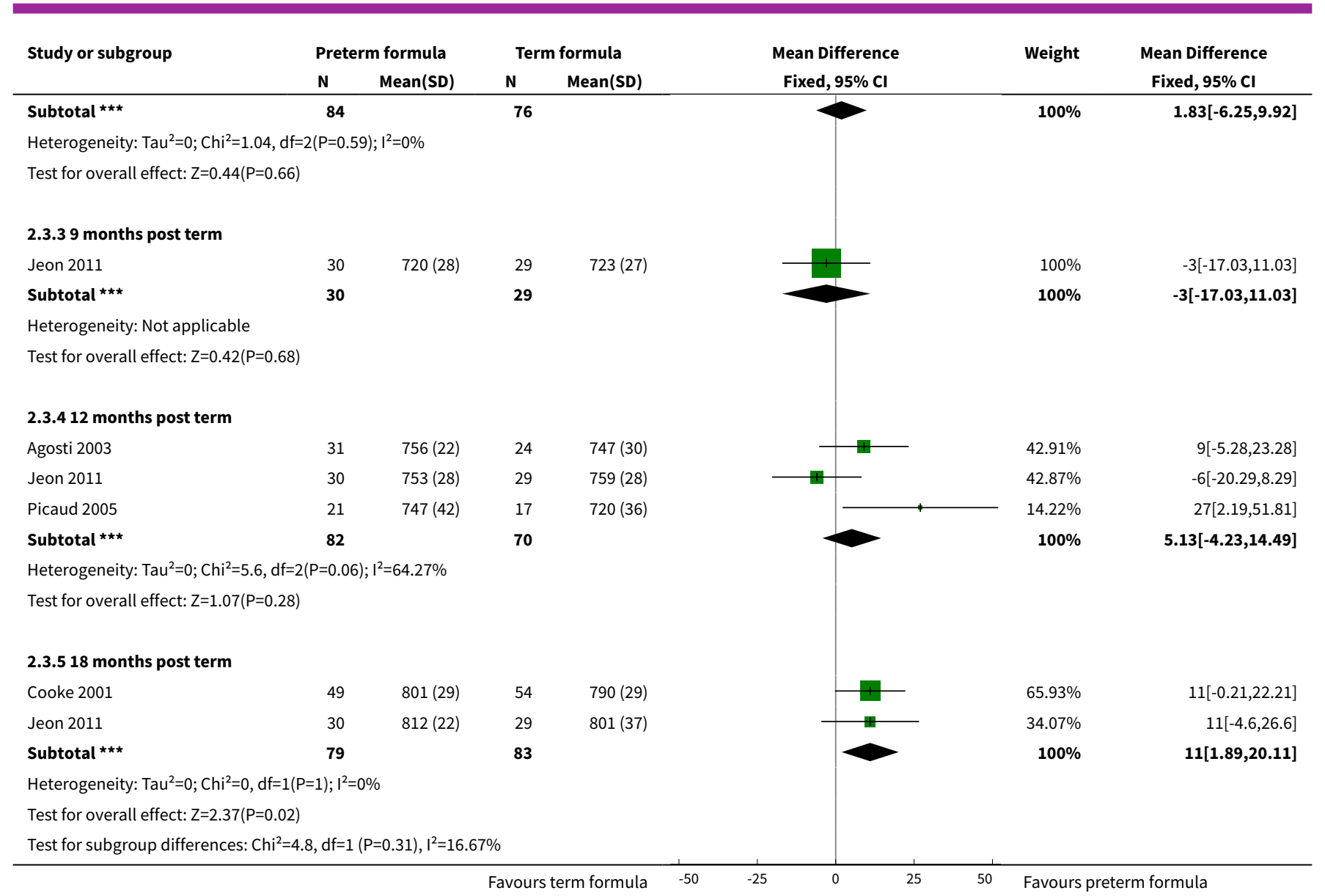

\section{Analysis 2.4. Comparison 2 Preterm formula versus standard term formula, Outcome 4 Head circumference (mm).}

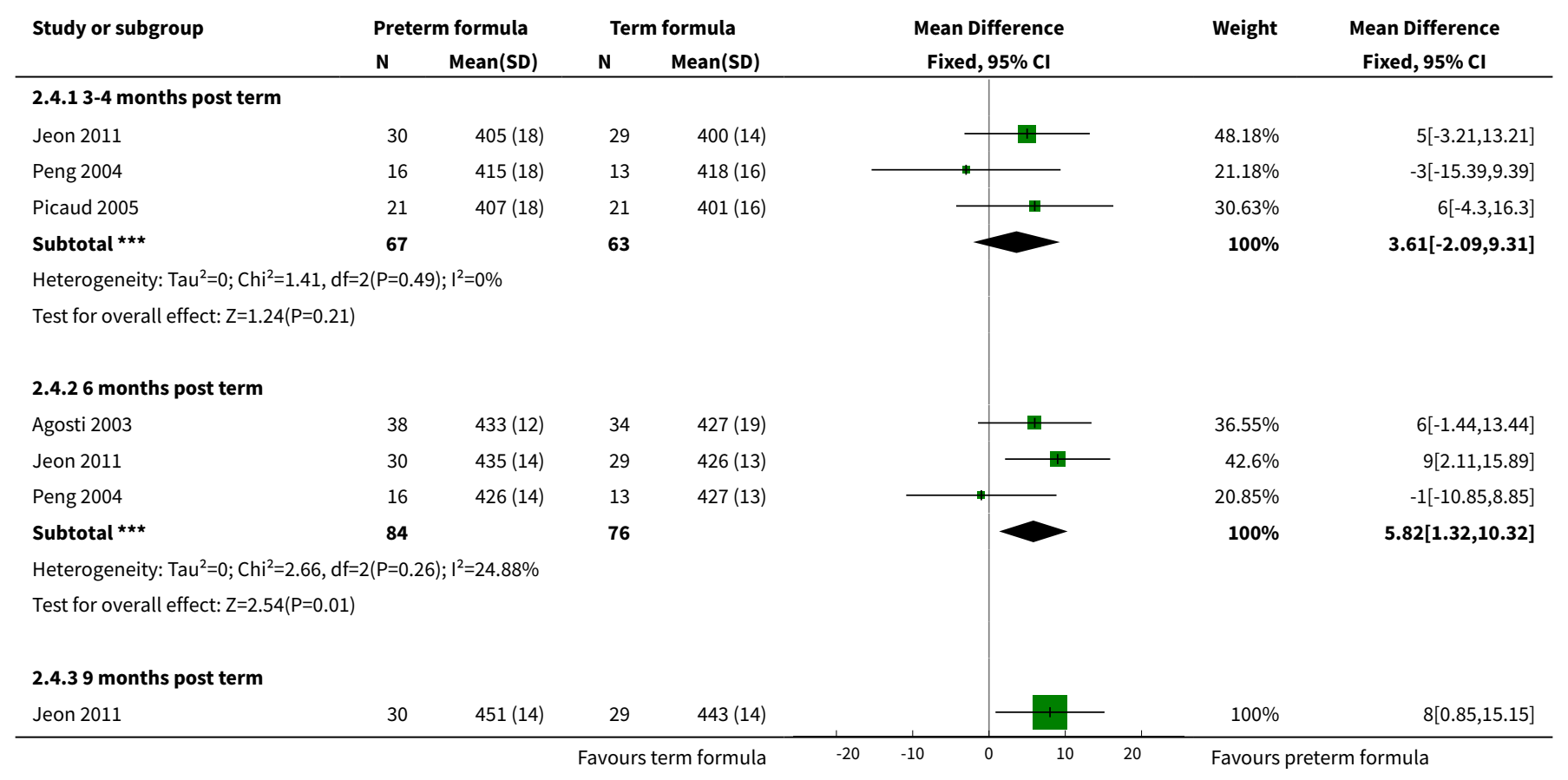




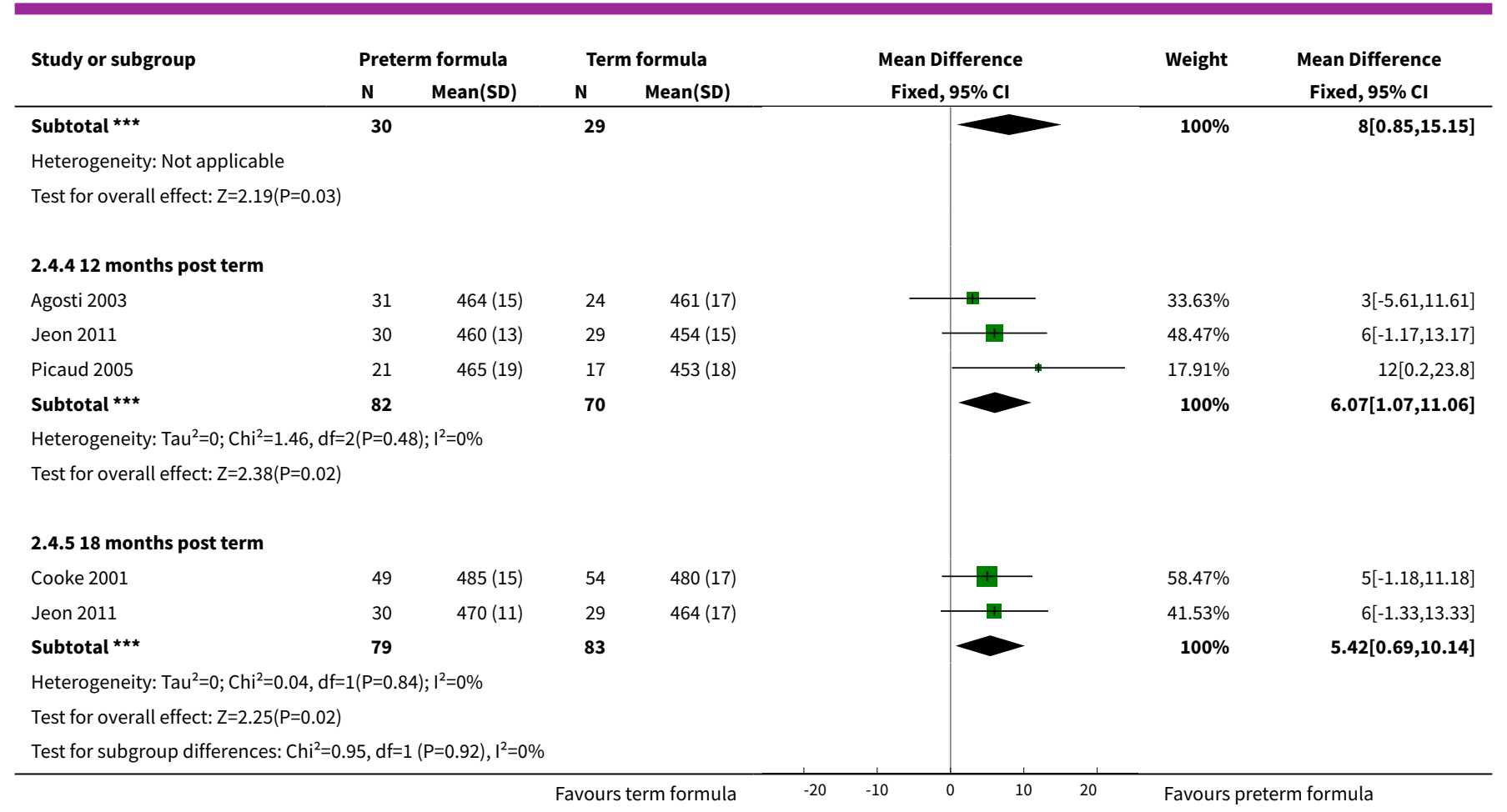

\section{Analysis 2.5. Comparison 2 Preterm formula versus standard term formula, Outcome 5 Development.}

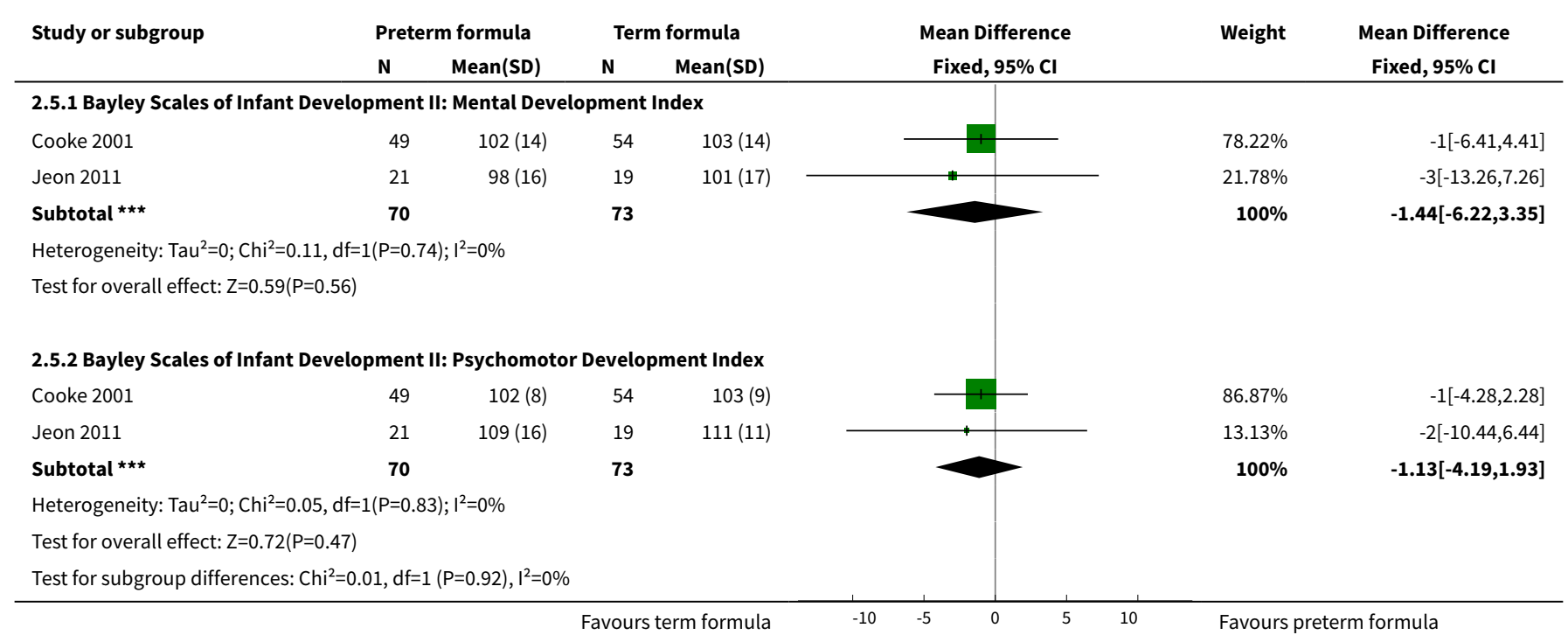

\section{WHAT'S NEW}

\begin{tabular}{lll}
\hline Date & Event & Description \\
\hline 8 September 2016 & $\begin{array}{l}\text { New citation required but conclusions } \\
\text { have not changed }\end{array}$ & Search updated; 1 new trial added; conclusion unchanged \\
\hline
\end{tabular}




\begin{tabular}{lll}
\hline Date & Event & Description \\
\hline 8 September 2016 & New search has been performed & One new trial added (Roggero 2011) \\
\hline
\end{tabular}

\section{HIST O R Y}

Protocol first published: Issue 2, 2004

Review first published: Issue 2, 2005

\begin{tabular}{|c|c|c|}
\hline Date & Event & Description \\
\hline \multirow[t]{4}{*}{28 October 2011} & $\begin{array}{l}\text { New citation required and conclusions } \\
\text { have changed }\end{array}$ & $\begin{array}{l}\text { Updated search; included } 8 \text { new trials as reported by trial au- } \\
\text { thors }\end{array}$ \\
\hline & & $\begin{array}{l}\text { Revised review structure; specified separate comparisons of } \\
\text { preterm formula and postdischarge formula vs standard term } \\
\text { formula }\end{array}$ \\
\hline & & Modified conclusions \\
\hline & & Added new review authors \\
\hline 28 October 2011 & New search has been performed & $\begin{array}{l}\text { This updates the review, "Nutrient-enriched formula versus stan- } \\
\text { dard term formula for preterm infants following hospital dis- } \\
\text { charge" (McGuire 2007). }\end{array}$ \\
\hline 28 April 2008 & Amended & Converted to new review format \\
\hline 25 June 2007 & $\begin{array}{l}\text { New citation required but conclusions } \\
\text { have not changed }\end{array}$ & Made substantive amendments \\
\hline
\end{tabular}

\section{CONTRIBUTIONS OF AUTHORS}

William McGuire and Lauren Young undertook the electronic search and identified citations for possible inclusion. Lauren Young, William McGuire and Nick Embleton reviewed the citation list (title and abstract) for inclusion and undertook methodological appraisal and data extraction, entry and analysis. William McGuire acted as an arbiter for disagreements, reviewed data entered and analysed and completed the review.

\section{DECLARATIONS OF INTEREST}

Nick Embleton has conducted research with support from manufacturers of infant formula including Nestec SA (Switzerland), Wyeth UK and Nutricia UK, but did not receive payment, support nor benefit in kind for contributions to this review.

\section{SOURCES OF SUPPORT}

\section{Internal sources}

- Centre for Reviews and Dissemination, University of York, UK.

- Royal Victoria Infirmary, Newcastle upon Tyne, UK.

\section{External sources}

- NIHR, UK.

This report is independent research funded by a UK National Institute of Health Research Grant (NIHR) Cochrane Programme Grant (13/89/12). The views expressed in this publication are those of the review authors and are not necessarily those of the NHS, the NIHR or the UK Department of Health. 
- Eunice Kennedy Shriver National Institute of Child Health and Human Development, National Institutes of Health, Department of Health and Human Services, USA.

Editorial support of the Cochrane Neonatal Review Group has been provided by Federal funds from the Eunice Kennedy Shriver National Institute of Child Health and Human Development, National Institutes of Health, Department of Health and Human Services, USA, under Contract No. HHSN275201600005C.

\section{DIFFERENCES BETWEEN PROTOCOLANDREVIEW}

We added the methods and plan for Summary of findings tables and GRADE recommendations, which were not included in the original protocol nor in the previously published review.

\section{INDEX TERMS}

\section{Medical Subject Headings (MeSH)}

*Infant Formula [standards]; Child Development [ ${ }^{*}$ physiology]; Dietary Proteins [administration \& dosage]; Energy Intake [ ${ }^{*}$ physiology]; Infant Nutritional Physiological Phenomena; Infant, Low Birth Weight [growth \& development]; Infant, Premature [^growth \& development]; Patient Discharge; Randomized Controlled Trials as Topic

\section{MeSH check words}

Humans; Infant; Infant, Newborn 